UNIVERSIDADE DE SÃO PAULO

FACULDADE DE FILOSOFIA CIÊNCIAS E LETRAS DE RIBEIRÃO PRETO PROGRAMA DE PÓS-GRADUAÇÃO EM PSICOLOGIA DEPARTAMENTO DE PSICOLOGIA E EDUCAÇÃO

\title{
GRUPO DE APOIO COM PACIENTES PSIQUIÁTRICOS AMBULATORIAIS: EXPLORAÇÃO DE ALGUNS LIMITES E POSSIBILIDADES
}

\section{Carla Guanaes}

Dissertação de Mestrado apresentada à Faculdade de Filosofia, Ciências e Letras de Ribeirão Preto da Universidade de São Paulo, como parte das exigências para a obtenção do título de Mestre em Psicologia.

RIBEIRÃO PRETO

2000 
UNIVERSIDADE DE SÃO PAULO

FACULDADE DE FILOSOFIA CIÊNCIAS E LETRAS DE RIBEIRÃO PRETO PROGRAMA DE PÓS-GRADUAÇÃO EM PSICOLOGIA DEPARTAMENTO DE PSICOLOGIA E EDUCAÇÃO

\section{GRUPO DE APOIO COM PACIENTES PSIQUIÁTRICOS AMBULATORIAIS: EXPLORAÇÃO DE ALGUNS LIMITES E POSSIBILIDADES}

\section{Carla Guanaes}

Dissertação de Mestrado apresentada à Faculdade de Filosofia, Ciências e Letras de Ribeirão Preto da Universidade de São Paulo, como parte das exigências para a obtenção do título de Mestre em Psicologia.

RIBEIRÃO PRETO

2000 
UNIVERSIDADE DE SÃO PAULO

FACULDADE DE FILOSOFIA CIÊNCIAS E LETRAS DE RIBEIRÃO PRETO DEPARTAMENTO DE PSICOLOGIA E EDUCAÇÃO

\author{
GRUPO DE APOIO COM PACIENTES PSIQUIÁTRICOS \\ AMBULATORIAIS: EXPLORAÇÃO DE ALGUNS LIMITES E \\ POSSIBILIDADES
}

\begin{abstract}
Aluna: Carla Guanaes
Orientadora: Prof ${ }^{\mathrm{a}} \mathrm{Dr}^{\mathrm{a}}$ Marisa Japur
\end{abstract}

Dissertação de Mestrado apresentada à Faculdade de Filosofia, Ciências e Letras de Ribeirão Preto da Universidade de São Paulo, como parte das exigências para a obtenção do título de Mestre em Psicologia.

RIBEIRÃO PRETO - SP

2000 


\section{FICHA CATALOGRÁFICA}

\section{Preparada pela Biblioteca Central do Campus Administrativo de Ribeirão Preto - USP}

\section{Guanaes , Carla}

Grupo de apoio com pacientes psiquiátricos ambulatoriais: exploração de alguns limites e possibilidades. Ribeirão Preto, 2000.

149 p.: il.; $30 \mathrm{~cm}$

Dissertação de Mestrado, apresentada à Faculdade de Filosofia, Ciências e Letras de Ribeirão Preto/USP - Área de concentração: Psicologia Clínica / Institucional

Orientador: Japur, Marisa

1.Grupos de apoio. 2. pacientes ambulatoriais. 
"Nada acontece antes de ser sonhado" (Carl Sandburg)

A meus pais, Gabriel e Nazaré, pelo constante incentivo e respeito com que têm acompanhado cada uma de minhas escolhas, e também pelo amor e pela amizade com que me incentivaram em mais esta conquista.

"Grandes pensamentos vêm do coração" (Marquês de Vauvernagues, 1715-1747, ensaista francês)

\section{À Marisa Japur,}

Por toda a atenção com que me orientou durante todo este percurso Pela constante disponibilidade, mesmo em seus momentos mais dificeis Pelo acolhimento e amizade nos periodos de insegurança e dúvida Pelos conhecimentos que mostrou possuir Por sua postura ética, responsável e crítica.

A possibilidade de trabalhar ao seu lado não só tornou possível esta conquista como fez com que esta tivesse um sentido muito mais especial. Obrigada por ter acreditado na realização deste sonho. 


\section{Agradecimentos especiais}

Ao médico psiquiatra, coordenador do grupo objeto deste estudo, pela atenção com que aceitou participar do estudo e por sua disponibilidade em todos os contatos estabelecidos.Sua postura acolhedora possibilitou a concretização deste trabalho, assim contribuindo com conhecimentos sobre a prática clínica grupal no contexto institucional.

Aos integrantes do grupo objeto deste estudo, pela disponibilidade com que aceitaram participar da pesquisa, e pela consciência da importância de suas participações para o desenvolvimento da mesma. E também pela confiança apostada na pesquisadora nos momentos em que revelaram suas vivências cotidianas, suas dificuldades, angústias e incertezas.

À instituição em que se realizou a pesquisa, pela permissão dada à realização da mesma.

E também,

À professora Dra. Sônia Regina Loureiro, pela atenção e respeito com que me orientou em importantes momentos da realização deste estudo, e pelas valiosas contribuições dadas ao longo do desenvolvimento do projeto e a partir do exame de qualificação.

À professora Dra. Maria Auxiliadora Campos, pelas sugestões dadas a partir do exame de qualificação, e por seu olhar atencioso sobre o trabalho, que favoreceu a revisão de importantes aspectos deste.

A todos os amigos pelo incentivo e apoio com que se fizeram presentes, sobretudo nos momentos de dificuldades, em especial: Emerson Rasera, Emiliane Moreno Villava, Flávia de Lima Osório, Flávia Beckman e Daniel Oliveira Lopes.

Agradeço, ainda, a todos os que puderam contribuir, direta ou indiretamente, com que a realização deste trabalho se fizesse possível: 
Ao Programa de Pós-graduação em Psicologia da Faculdade de Filosofia, Ciências e Letras de Ribeirão Preto - USP, pelo crédito depositado na qualidade deste estudo. Aos professores do Departamento de Psicologia e Educação, pelos conhecimentos acrescentados à pesquisa a partir de suas disciplinas.

À Denise Cremonzi Vicente, secretária do programa de pós-graduação da Faculdade de Filosofia, Ciências e Letras de Ribeirão Preto, pelas orientações quanto às questões burocráticas durante o desenvolvimento deste estudo.

À Fundação de Apoio à Pesquisa do Estado de São Paulo (FAPESP), pelo apoio financeiro dado à pesquisa. 


\section{SUMÁRIO}

\section{LISTA DE TABELAS E QUADROS}

RESUMO

\section{PRÓLOGO}

1- INTRODUÇÃO.

1.1- A assistência em Saúde Mental em transformação: avanços e permanências.

1.2 - O emprego da psicoterapia de grupo no tratamento das patologias mentais

1.3- A diversidade das práticas psicoterápicas em grupo...

1.4- Grupos de curta duração e grupos de apoio: especificidades destas intervenções.

1.5- A pesquisa em psicoterapia de grupo e o referencial teóricometodológico dos fatores terapêuticos

2- OBJETIVOS

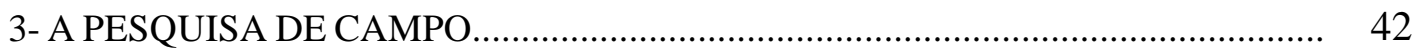

3.1- O delineamento metodológico do estudo............................................. 42

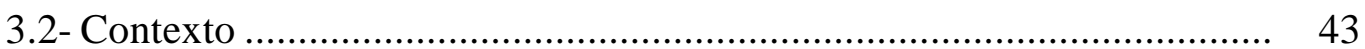

3.3- Consentimento Informado............................................................. 45

3.4- Materiais e Procedimentos de Coleta e Análise dos Dados.................. 46

3.4.1- Fontes complementares.......................................................... 46

3.4.2- Observação e Registro do grupo................................................. 48

3.4.3- Questionário do Incidente Crítico.............................................. 50

4- O GRUPO ESTUDADO .................................................................... 52

4.1- A composição do grupo.................................................................... 52

4.2- Caracterização dos pacientes.............................................................. 52

4.3- As sessões do grupo.................................................................. 65

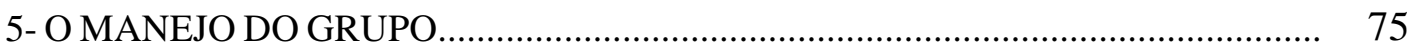


6- A VIVÊNCIA DOS PARTICIPANTES: FATORES TERAPÊUTICOS E NÃO TERAPÊUTICOS DO GRUPO.................................................................................. $\quad 85$

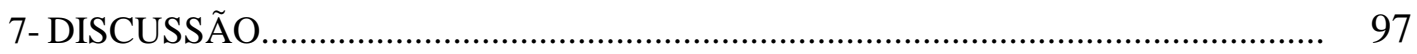

8- CONSIDERAÇÕES FINAIS................................................................................. 109

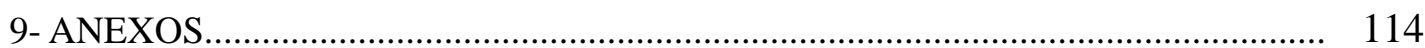

10- REFERÊNCIAS BIBLIOGRÁFICAS.............................................................. 141

SUMMARY 


\section{LISTA DE QUADROS, TABELAS E FIGURAS}

\section{QUADROS}

QUADRO 1 - Caracterização dos pacientes integrantes do grupo, incluindo sexo, idade, estado civil, grau de instrução e profissão, segundo os registros dos prontuários dos serviços

QUADRO 2 - Caracterização dos pacientes integrantes do grupo quanto a tratamentos psiquiátricos anteriores a seus atendimentos nos serviço

QUADRO 3 - Caracterização dos pacientes integrantes do grupo a partir do início de seu atendimento no serviço antecedendo à indicação e ingresso no grupo.

QUADRO 4 - História clínica psiquiátrica dos pacientes anterior ao início de sua participação no grupo, incluindo início de atendimento no serviço, condutas médicas anteriores e no momento do encaminhamento para o grupo, evolução e diagnóstico clínico no momento do encaminhamento........

QUADRO 5 - Condição clínica dos pacientes no momento de encaminhamento para o grupo, conforme as avaliações psiquiátricas registradas nos prontuários

QUADRO 6 - Ajustamento psicossocial dos pacientes conforme avaliação realizada pelo médico psiquiatra ao início e ao término do grupo

QUADRO 7 - Informações sobre a continuação do atendimento dos pacientes no serviço, no seguimento de quatro meses

QUADRO 8 - Descrição do desenvolvimento do grupo a partir de alguns vértices da temática e dinâmica de suas sessões.

FIGURAS

FIGURA 1 - Figura esquemática do sistema de Saúde da DIR-XVIII

FIGURA 2 - Presença dos participantes nas dezesseis sessões do grupo de apoio.

FIGURA 3 - Distribuição percentual das intervenções do coordenador $(\mathrm{N}=1904)$ no conjunto das sessões do grupo.

FIGURA 4 - Distribuição percentual das intervenções do coordenador, dirigidas ao paciente ou ao grupo por categorias de intervenção, no conjunto das sessões do grupo.

\section{TABELAS}

TABELA 1 - Distribuição das categorias de análise derivadas das respostas dos pacientes ao QIC ao longo das sessões do grupo.

TABELA 2 - Distribuição das categorias de análise derivadas das respostas dos pacientes ao QIC ao longo das sessões do grupo 


\section{LISTA DE ANEXOS}

ANEXO 1- Consentimento Informado

ANEXO 2- Formulário de Avaliação do Ajustamento Psicossocial dos pacientes ao início e ao término do grupo.

ANEXO 3- Intervenções do coordenador consideradas no cálculo da fidedignidade do sistema de categorias descritivo do manejo do grupo.....

ANEXO 4- Questionário do Incidente Crítico

ANEXO 5- Manual de Classificação dos fatores terapêuticos

ANEXO 6- História dos pacientes referente a período anterior a seu atendimento no serviço.

ANEXO 7- História clínica psiquiátrica dos pacientes antecedendo o encaminhamento para o grupo e a partir do início de seu atendimento no serviço.

ANEXO 8- Condição dos pacientes no momento de encaminhamento para o grupo, tendo em vista suas principais queixas, seus diagnósticos (CID-10) e o uso ou não de medicação.

ANEXO 9- Avaliação do Ajustamento Psicossocial dos pacientes ao início e ao término do grupo.

ANEXO 10- Informações sobre o seguimento dos pacientes durante follow up de quatro meses após o término do grupo.

ANEXO 11- Freqüência de participação dos pacientes no grupo de apoio.

ANEXO 12- Distribuição percentual das intervenções do coordenador nas sessões do grupo $(\mathrm{N}=1904)$ pelas categorias de intervenção 


\section{GRUPO DE APOIO COM PACIENTES PSIQUIÁTRICOS AMBULATORIAIS: EXPLORAÇÃO DE ALGUNS LIMITES E POSSIBILIDADES}

\section{RESUMO}

O emprego da psicoterapia de grupo no atendimento em saúde mental, sobretudo em contextos institucionais, tem se expandido em ritmo acelerado em nossa realidade, não havendo uma expansão correlata de pesquisas na área, conforme aponta a literatura especializada. Esse estudo visa contribuir com o conhecimento sobre essa prática, estudando um grupo de apoio com pacientes psiquiátricos ambulatoriais (16 sessões), em condições naturais, em um serviço de saúde mental de Ribeirão Preto. Objetivou-se compreender as possibilidades e limites dessa intervenção descrevendo o desenvolvimento do grupo através das formas de manejo do coordenador e investigando os fatores terapêuticos presentes no grupo segundo a perspectiva de seus participantes. O grupo foi composto por dez pacientes de ambos os sexos, de 29 a 65 anos, predominantemente casados e com escolaridade de $1^{\circ}$ grau incompleto. Com diagnósticos psiquiátricos diversos, tinham indicação prevalente de uso de medicação ansiolítica e/ou antidepressiva. Observação e registro audio-gravado do grupo e Questionário do Incidente Crítico (QIC) constituíram as principais fontes de dados. Consultas aos prontuários dos pacientes e notas de campo também foram realizadas durante o período de coleta de dados. Os dados foram analisados por procedimentos qualitativos e quantitativos. Efetuou-se, com base na transcrição e nos registros de observação das sessões, a descrição da temática e da dinâmica das mesmas. A análise do manejo do grupo foi realizada por procedimentos de análise categorial de conteúdo das intervenções do coordenador $(\mathrm{N}=1904)$. A análise das respostas dos pacientes ao QIC $(\mathrm{N}=112)$, foi realizada por procedimentos de análise categorial de conteúdo, tendo como base um sistema descritivo dos fatores terapêuticos proposto na literatura. Os dados dos prontuários e as anotações de diário de campo foram utilizados na contextualização dos dados derivados da análise das outras fontes. Os resultados da análise do manejo do grupo nos remetem a oito categorias de intervenção: reiteração (48\%); investigação (16\%); elucidação (13\%); confrontação (11\%); enquadre (7\%); avaliação (2\%); orientação (1\%) e fala interrompida (2\%). O sistema a priori de categorias de análise do QIC não se mostrou suficiente para a classificação de todas as respostas, levando à criação de novas categorias. Nossos resultados apontam para a presença de dez categorias derivadas da percepção dos pacientes sobre o grupo: universalidade (23\%); aprendizagem vicária (22\%); distanciamento (13\%); desesperança (9\%); instilação de esperança (7\%); altruísmo (6\%); aceitação (5\%); auto revelação (4\%); orientação (4\%) e catarse (3\%). Apenas 5\% das respostas ao QIC foram não classificáveis. Estes resultados remetem à presença de fatores terapêuticos e não terapêuticos no grupo, tal como vivenciado pelos pacientes. Assim, este estudo possibilita uma compreensão sobre o modo como os pacientes vivenciaram o processo deste grupo tendo em vista os sentidos que produziram a partir de sua participação neste - e, em conjunção com seus quadros clínicos e com o entendimento sobre o funcionamento do grupo através da descrição de seu manejo, situa algumas possibilidades e limites deste tipo de tratamento, considerando o contexto em que ocorre e a clientela que usualmente o integra. (FAPESP)

Palavras chaves: grupos de apoio; pacientes ambulatoriais. 


\section{PRÓLOGO}

A prática da psicoterapia de grupo tem apresentado um acentuado crescimento em nossa realidade, sobretudo determinada por pressões de ordem econômica e modificações nas concepções sobre as formas de tratamento em saúde mental. Embora respondendo também à necessidade de redução dos custos e de aumento do índice de atendimentos em psicoterapia, esta prática tem se expandido e se mostrado uma modalidade de intervenção viável em decorrência de avanços teóricos e técnicos nesse campo. O panorama atual revela uma multiplicidade de intervenções psicoterápicas em grupo nos mais variados contextos, e evidencia a crescente aceitação desta prática entre os profissionais e entre os próprios pacientes, sobretudo nas instituições.

Meu contato pessoal com a prática clínica de grupo iniciou-se através do meu curso de graduação em Psicologia, a partir da experiência em diferentes contextos e posicionamentos: como integrante de grupos de reflexão profissional e como coterapeuta de um grupo em contexto ambulatorial em atividade de estágio. Este contato inicial foi suficiente para despertar meu interesse por esta forma de atendimento, que me parecia tão infinita em suas possibilidades. Após a graduação, permaneci como profissional voluntária, na função de co-terapeuta, de um grupo para pacientes psiquiátricos ambulatoriais em uma instituição pública, do qual já fazia parte como estagiária no semestre anterior. Além da possibilidade de vivenciar esta prática e aprimorar meus conhecimentos sobre o fenômeno grupal, considero esta experiência como pessoalmente enriquecedora, por ter possibilitado o contato com a diversidade do grupo e com parte da realidade dos serviços públicos de atendimento.

Destas experiências surgiu o interesse pela pesquisa, a fim de tentar melhor compreender a complexidade deste fenômeno e as possibilidades oferecidas pela interação humana no desenvolvimento de potencialidades individuais.Assim, minha curiosidade inicial pôde se transformar em uma pesquisa sistematizada sobre a prática grupal a partir do desenvolvimento desse estudo, em que pude observar um grupo de outra natureza (grupo de apoio), realizado em outra instituição de saúde, e também dirigido ao atendimento de pacientes psiquiátricos ambulatoriais. 


\section{1 - INTRODUÇÃO}

Daremos início a este estudo apresentando o contexto de desenvolvimento da psicoterapia de grupo e as condições que influenciaram seu crescente emprego no tratamento das patologias mentais. Entendendo que esta prática desenvolveu-se também por influências do contexto sócio-cultural e por mudanças nas concepções sobre a doença mental, apresentaremos um breve histórico procurando apontar como a psiquiatria evoluiu em sua compreensão sobre o fenômeno da "loucura" e sobre as possibilidades de tratamento ao doente. A evolução da psiquiatria em direção a uma prática ao mesmo tempo política e clínica possibilitou uma maior compreensão da doença mental em função de seus aspectos bio-psico-sociais, além de contribuir com a busca da cidadania de seus pacientes a partir de sua inclusão na vida social.

Buscaremos demonstrar que o desenvolvimento da psiquiatria em direção a uma maior compreensão da doença mental relaciona-se intimamente ao contexto histórico e cultural das épocas que atravessou, assim determinando e sendo determinado por políticas sociais e pelas mudanças nas concepções sobre a doença, o que modificou, por conseguinte, sua prática clínica e as modalidades de atendimento possíveis no campo da Saúde Mental.

Após uma apresentação das transformações ocorridas nesse campo e das reformas nas concepções e formas de tratamento do doente mental, abordaremos especificamente o crescente emprego das práticas psicoterápicas em grupo, por representarem modalidades de atendimento que ganharam espaço a partir destas transformações.

Sendo este trabalho orientado para a compreensão da natureza de um grupo de apoio de curta duração, voltaremos nossa atenção particularmente a este tipo de grupo, assim melhor delimitando sua especificidade. Então, passaremos a abordar a prática grupal e as possibilidades de investigação científica na área, situando a complexidade de pesquisas neste campo, e tomando o referencial teórico metodológico dos fatores terapêuticos como instrumental em nossa abordagem do fenômeno. 


\section{1- A assistência em Saúde Mental em transformação: avanços e permanências}

As primeiras políticas de saúde oficiais do Estado brasileiro que regulamentavam formas de intervenção junto ao paciente portador de "doença mental" foram marcadas por processos de marginalização e exclusão social, segundo a literatura sobre o tema.

Segundo LUZ (1994), o Estado brasileiro começa a manifestar sua preocupação com a saúde coletiva apenas a partir da segunda metade do século XIX. Especificamente em relação à saúde mental, esta preocupação manifesta-se a partir de políticas de marginalização, caracterizadas por "formas sistemáticas de exclusão econômica e social de setores da sociedade" (p.86).

A primeira lei de assistência ao doente mental no Brasil data de 1852, e veio seguida da criação do primeiro hospital público - o Hospital D. Pedro II (1852), no Rio de Janeiro. Conforme nos aponta MARSIGLIA (1987), estas políticas de assistência originaram-se em resposta à necessidade de preservar a sociedade da periculosidade que o doente mental representava, numa época em que era escasso qualquer conhecimento maior sobre o fenômeno da loucura. Neste contexto, estas políticas acabaram por formalizar a "política oficial de tutela e segregação do doente mental" (p.18), dando início às medidas de isolamento deste grupo do convívio social.

A partir de 1890, o Brasil presenciou o desenvolvimento das medidas de tutela por parte do Estado, sobretudo com a criação do Serviço de Assistência aos alienados. Também a legislação que se desenvolveu a partir do Código Civil de 1916 e da lei de 1919, estabelecendo que "são absolutamente incapazes de exercer pessoalmente os atos da vida civil os loucos de todo o gênero" ( $\left.\operatorname{art} .5^{\circ}, \operatorname{pr} .2^{\circ}\right)$, definia, em relação ao doente mental, que como ele não era produtivo e não tinha profissão regulamentada, não podia ser considerado cidadão, continuando tutelado pelo Estado e excluído da vida em sociedade. Tempos depois, a lei de 1934 estabeleceu que deveria haver, por parte do Estado, assistência e proteção a pessoa e aos bens do psicopata, que incluía os toxicômanos e alcoólatras, assim ampliando a ação federal a partir da criação da Divisão de Assistência ao Doente Mental. Além disso, um decreto-lei específico ao doente mental e o Código Penal de 1940 incorporaram a noção de periculosidade do doente, assim recomendando o recolhimento ao 
manicômio, às casas de custódia e colônias agrícolas dos indivíduos considerados perigosos, devendo o Estado retirá-los do convívio social (MARSIGLIA 1987).

Esta política de isolamento do doente mental, concretizada a partir da criação dos manicômios, assemelha-se aos processos de exclusão vivenciados por outros grupos marginalizados na sociedade capitalista e burguesa do século XIX, como os negros, as mulheres, os pobres e os presidiários, entre outros.

Segundo RESENDE (1992),

“...a premência e a preeminência da função saneadora dos primeiros hospícios dão às origens da assistência psiquiátrica brasileira um aspecto bastante peculiar, qual seja, o da precedência da criação de instituições destinadas especificamente a abrigar os loucos sobre o nascimento da psiquiatria, enquanto corpo de saber médico e institucionalizado" (p.37).

Assim, a psiquiatria da época exercia finalidades mais políticas do que médicas, já que os hospícios caracterizavam-se menos por suas finalidades terapêuticas do que de exclusão social. Nas palavras de COSTA \& TUNIS (1992), “a ideologia psiquiátrica teria nascido para tornar possível classificar como doente mental todo o comportamento inadaptável aos limites da liberdade burguesa" (p.12).

A diferenciação da psiquiatria em termos de conteúdo, de organização interna e de prática, de todo o restante da ciência médica deu-se por condições ligadas, conforme apontou Foucault apud SILVA FILHO (1992), a "um jogo de relações entre a hospitalização, a internação, as condições e os procedimentos da exclusão social, as regras de jurisprudência, as normas do trabalho industrial e da moral burguesa" (p.79).

Nesta mesma perspectiva, BARROS (1994) afirma que "a condenação moral e a privação da liberdade pessoal precedeu à discussão sobre o fenômeno da loucura" (p.190), que passou a ser considerado equivalente à doença mental ao longo de um processo histórico que embasou o saber psiquiátrico.

Assim, foi através de uma prática considerada preventiva que se concretizou uma política assistencial de isolamento que, carecendo de uma compreensão clínica sobre a doença mental, não podia exercer fins terapêuticos, assim tendo como finalidade única precaver a sociedade burguesa dos males que os alienados poderiam causar (GIOVANELLA \& AMARANTE, 1994). 
Parece-nos fundamental esta sintética apresentação histórica para a compreensão das políticas que se seguiram e das propostas de reformulação do modelo manicomial.

Um novo olhar para a questão asilar parece ter sido possível apenas a partir da Revolução Francesa e dos avanços do capitalismo, a partir de noções sobre a necessidade de preservação da mercadoria força de trabalho. Neste contexto, o manicômio assume novo significado, alertando para a possibilidade de reabilitação da enorme massa populacional ali inerte e que poderia se aliar ao sistema produtivo. Mais uma vez, a psiquiatria terá seu desenvolvimento articulado a esta nova realidade social.

Nesta mesma perspectiva, também a $2^{\mathrm{a}}$ Guerra Mundial funcionou como estímulo às mudanças nas concepções e modalidades de atendimento em Saúde Mental, já que as baixas no número de soldados representavam déficits na força produtiva, ameaçando a economia capitalista. Assim, no pós-guerra "o novo lema era dinamizar a estrutura hospitalar, criar novas formas e condições de tratamento para uma eficaz recuperação dos pacientes como sujeitos de produção (BIRMAN \& COSTA, 1994, p.49)".

É neste contexto histórico que surge, de dentro da própria psiquiatria, as primeiras críticas ao modelo psiquiátrico vigente, a partir de questionamentos sobre o hospital psiquiátrico em sua função terapêutica, podendo-se assim pensar formas alternativas a esta realidade. Denúncias relativas ao sistema anterior de exclusão e marginalização vêm à tona, ainda que inicialmente vinculadas aos novos interesses da sociedade capitalista. Assim, há uma modificação radical na perspectiva psiquiátrica, que passa a defender ao invés da "cura", a adaptação do paciente ao grupo social, sendo que o objeto da psiquiatria deixa de ser a doença e passa a ser a "Saúde Mental". Segundo BIRMAN \& COSTA (1994), este objeto tem linhas bem demarcadas:

“(1) a Saúde Mental é definida em termos adaptativos, como a capacidade do sujeito de integrar-se num grupo; e 2) adaptar-se num pequeno grupo representa a possibilidade de submeter-se, nem que seja aparentemente, às suas regras, formuladas por seus líderes formais, que se traduzem na sua linguagem e na realização de tarefas práticas" (p.52). 
Baseando-se nestas noções, no período de 1955 a 1963, políticas foram criadas nos EUA visando a regulamentação da assistência psiquiátrica. Em 1963, o presidente Kennedy formula uma nova política para o tratamento do doente mental, que passa a ser referência para todo o mundo. Trata-se de uma abordagem preventiva da doença, a partir de três níveis: 1) prevenção primária: intervenções dirigidas às condições possíveis de formação da doença; 2) prevenção secundária: que busca a realização de diagnósticos e tratamento precoces da mesma; e 3) prevenção terciária: que se define pela busca da readaptação do paciente à vida social, após a sua melhora (BIRMAN \& COSTA, 1994, p.54). Nesta perspectiva,

"prevenir, palavra ambígua, implica em adaptar, em equilibrar os contextos socialmente tensos, desde o seu surgimento, como forma de bloquear o surgimento do desvio e do marginalismo dos grupos constituídos, já que são ameaças reais e (ou) simbólicas, para a sua dissolução" (BIRMAN \& COSTA, 1994, p.56).

Ainda assim, esta política americana concebia a assistência psiquiátrica de maneira mais global, criticando o macro-hospital e propondo unidades ainda hospitalares, porém menores.

Dentro de uma perspectiva mais revolucionária, a Itália também passou a repensar suas políticas assistenciais em Saúde Mental, sob uma proposta que veio a ser conhecida sobretudo por seus princípios democráticos e humanísticos. A legislação de 1978, conhecida como a Lei da Reforma Psiquiátrica (Lei 180), regulamentava a eliminação das internações psiquiátricas e a construção de serviços na comunidade que substituíssem inteiramente a própria internação. Os hospitais de Trieste e de Gorizia são hoje mundialmente conhecidos por suas modificações em nível de estrutura e de atendimento aos portadores de doença mental, rompendo com o sistema manicomial vigente até então e propondo outras possibilidades de intervenção em substituição aos modelos anteriores (KINOSHITA, 1987).

Segundo Franco Basaglia, conhecido representante das propostas de reforma da psiquiatria italiana, o movimento de reformulação das políticas de saúde nasceu de uma série de recusas e negações: 
"recusa antes de mais nada, do mandato social que o psiquiatra hospitalar recebe e passivamente desenvolve, isto é, aquele de segregar os internos e de custodiá-los de modo que percam a possibilidade de fazer escolhas autônomas e responsáveis" (BASAGLIA, ONGARO, CASAGRANDE, JUVIS, COMBA, PIRELLA, SCHITTAR \& SLAVICH, 1994, p.22).

Para estes autores, essas posições iniciais de recusa da situação opressora, apareciam sob a forma de uma modalidade de convivência mais ou menos comunitária, que rompia com a violência e as funções hierárquicas tradicionais, derivando-se nos processos de desinstitucionalização. Assim,

"no pós-guerra, os avanços tecnológicos e científicos, a reestruturação das economias, as reformas sociais e sanitárias, a valorização do trabalho na reconstrução dos países e a necessidade de ampla participação das sociedades nacionais, mobilizaram recursos novos e ampliados capazes de modificar profundamente o quadro de necessidades profissionais e técnicas na abordagem dos transtornos mentais" (PADRÃO, s/d, p.03).

Deste modo, países como os Estados Unidos, Canadá, e vários países europeus, especialmente a Grã-Bretanha, a França e a Itália, combinando reformas legislativas e assistenciais, puderam diminuir a população manicomial e promover novos modelos de atenção à Saúde mental, resgatando alguns dos direitos civis de seus usuários.

Enquanto as políticas de reforma psiquiátrica internacionais versavam sobre propostas de desospitalização e/ou de desinstitucionalização, associadas a posturas democráticas, o Brasil vivenciava políticas absolutamente reversas, fruto da ditadura militar do período de 1964 (CAMPOS, 1997). De acordo com PADRÃO (s/d), justamente neste período, o Brasil possuía "um dos maiores parques manicomiais do mundo, chegando a mais de cem mil leitos psiquiátricos".

Segundo afirma MOURA NETO (1987), as políticas de saúde do Brasil durante o período militar acabavam por transformar o doente em uma mercadoria, sendo sua doença uma fonte de lucro, o que perpetuava o sistema assistencial e a criação de novos asilos psiquiátricos. Após a criação do INPS em 1967, o Estado subsidiava o desenvolvimento do setor privado de prestação de assistência médica, o que na área de saúde mental, facilitou a criação de um amplo 
“...sistema de hospitais psiquiátricos particulares que, somando-se às instituições públicas existentes, consolidou um modelo assistencial asilar completamente falido, excludente, discriminatório, perverso e corrupto" (p.52).

Por tudo isto, a montagem de modelos alternativos de atenção em saúde mental no contexto brasileiro deu-se apenas no começo da década de 80, como resultado de movimentos no campo da saúde mental e de reforma na assistência psiquiátrica - a denominada reforma sanitária (VASCONCELOS, 1995). Ainda assim, por muitos anos, "a incipiente rede de ambulatórios era incapaz de oferecer mais do que tratamentos farmacológicos ou guias de internação", assim perpetuando a condição de falência do sistema assistencial brasileiro (YASUI, 1989).

Em 1986, a $8^{\text {a }}$ Conferência Nacional de Saúde e a Conferência Nacional de Saúde Mental realizada a seguir, sugeriram reformulações nas políticas nacionais de saúde mental, denunciando as tendências de transformação do hospital psiquiátrico como centro de atendimento e sugerindo a desospitalização como início de uma política de reforma (CONSELHO REGIONAL DE PSICOLOGIA- 6a região, 1997).

Então, a nova Constituição do Brasil, promulgada em 1988, proclama que todo cidadão tem direito à saúde e contempla a criação de um serviço nacional de saúde, baseado na habilitação dos serviços locais sob o controle dos municípios. Conhecida como a constituição cidadã, esta legislação evidenciou as

“...mazelas e as profundas contradições da sociedade e do Estado brasileiro, já que ao promover a extensão e ampliação dos direitos, não se garantiu necessariamente o aprofundamento e a radicalidade das reformas institucionais" (PADRÃO, s/d, p.06).

Exerce também influência significativa neste processo de reformas e concessões o fato do Movimento dos Trabalhadores em Saúde Mental assumir-se, em 1987, como movimento social, contribuindo com a expansão do debate sobre saúde e loucura. Assim, o tema atinge a comunidade através do lema "por uma sociedade sem manicômios", e propicia, no campo prático, uma discussão mais abrangente sobre a adoção de políticas de desinstitucionalização. Concebe-se, neste momento, que a desinstitucionalização não implica apenas em projetos de desospitalização, mas na conseqüente invenção de práticas assistenciais territoriais e 
de processos de desconstrução de conceitos e de práticas psiquiátricas (AMARANTE, 1994).

É neste contexto que se desenvolve o projeto lei 3657-B (1989), de autoria do deputado Paulo Delgado, que dispõe sobre a extinção progressiva dos manicômios e sua substituição por outros recursos assistenciais, além de regulamentar a internação psiquiátrica compulsória. AMARANTE (1994) nos aponta que

\begin{abstract}
"ao propor a extinção progressiva dos hospitais psiquiátricos e sua substituição por novas modalidades de atendimento e práticas assistenciais, desencadeia um amplo debate nacional, realmente inédito, quando jamais a psiquiatria esteve tão permanente $\mathrm{e}$ consequientemente discutida por amplos setores sociais" (p.128).
\end{abstract}

Em 1991, a Declaração da ONU (Organização das Nações Unidas) surge estabelecendo alguns princípios universais, ao versar sobre "a proteção de pessoas acometidas de transtorno mental e a melhoria da assistência à saúde mental”, assim favorecendo o respeito, o resgate da cidadania e dos direitos civis dos pacientes. (CONSELHO REGIONAL DE PSICOLOGIA, 6a região, 1997). Esta declaração assume importância a nível internacional, e assim impulsiona algumas mudanças que já estavam em andamento no contexto brasileiro.

Frente às modificações nas concepções e nas formas de tratamento das doenças mentais,

“...em 1991, a Coordenação de Saúde do Ministério de Saúde inicia um processo de reestruturação da assistência em saúde mental, implementando o financiamento de uma rede de assistência extrahospitalar, ainda embrionária, apoiando a abertura de leitos psiquiátricos em hospitais gerais e, paralelamente, instituindo regras mais rígidas para $\mathrm{o}$ funcionamento dos serviços hospitalares psiquiátricos" (SCHICHTMAM, ALVES \& SILVA, 1996, p.128) ${ }^{1}$

\footnotetext{
${ }^{1}$ Apesar deste processo de reestruturação da assistência em psiquiatria ter se formalizado apenas nesta data, há registros de algumas experiências anteriores que se constituíram enquanto formas de atendimento alternativas ao sistema hospitalar. SCHERER (1999) refere as experiências de Ferrão, em 1954, a partir da inauguração de uma unidade de internação em hospital geral, em São Paulo; e de Blaya, na Clínica Pinel de Porto Alegre, e de Azoubel Neto, no serviço de psiquiatria da Faculdade de Medicina de Ribeirão Preto, ambos em 1961, iniciando o trabalho em hospital dia, em regime de comunidade terapêutica.
} 
Além disto, foram de acentuada importância outros congressos, conferências, portarias e projetos-leis que versavam sobre as políticas assistenciais em Saúde Mental, promovendo e estimulando debates para a melhoria deste sistema. Entre estes, vale lembrar: a Declaração de Caracas, de 1990; a Portaria MS 224, do Ministério de Saúde, de 1992; a $2^{a}$ Conferência Nacional de Saúde Mental,de 1992; o I Encontro Nacional da Luta antimanicomial,em 1993; a Carta de Direitos dos Usuários e Familiares de serviços de Saúde Mental, de 1993; o II Encontro Nacional da Luta Antimanicomial, e a “Lei Complementar 791”, ambos de 1995, de autoria do deputado Paulo Gouveia, entre outros (CONSELHO REGIONAL DE PSICOLOGIA, $6^{\mathrm{a}}$ região, 1997).

A partir de então, presenciou-se o desenvolvimento de novas possibilidades de assistência no campo da Saúde Mental em muitos Estados, sobretudo no centrosul e sul do Brasil: centros e núcleos de atenção psicossocial, hospitais-dia, centros de convivência, oficinas terapêuticas, lares abrigados, cooperativas e grupos de trabalho, etc. Porém, a implementação destes projetos, ainda hoje, encontra dificuldades referentes a:

\begin{abstract}
"inexistência de modelos teóricos adequados à realidade brasileira; culturas profissionais muito voltadas para práticas hospitalares ou para prática liberal em consultórios particulares; a resistência do setor hospitalar privado, bem como a atual crise do setor estatal de serviços sociais e de saúde, implicando em péssimas condições de trabalho, baixos salários, tendência a multi-emprego e jornadas parciais de trabalho, baixo investimento em recursos humanos em geral e treinamento, que têm dificultado enormemente o desenvolvimento de uma cultura profissional e uma metodologia de trabalho adequada aos novos serviços" (VASCONCELOS, 1995, p.190).
\end{abstract}

Para melhor compreendermos estas dificuldades vivenciadas nas tentativas de implementação dos novos modelos de atendimento, retomaremos o processo histórico aqui já referido, tentando abordar parte das concepções subjacentes às propostas de mudanças dos modelos de atendimento tradicionais.

Segundo editado pela ORGANIZAÇÃO PANAMERICANA DE SAÚDE (1990), relativo às memórias da Conferência Regional para a Reestruturação da Assistência Psiquiátrica, de Caracas - Venezuela, a crítica ao modelo manicomial que se iniciou de fato apenas em fins da $2^{\mathrm{a}}$ Guerra Mundial, teve seus precursores na psiquiatria 
fenomenológica (Yaspers /1913; Minkowsky /1927 e Biswnager /1951) e nas escolas psicodinâmicas, com o respaldo teórico dado à humanização terapêutica. Teóricos como Goffman, Foucault, Laing e Cooper, também se destacam na medida em que consolidaram, nas últimas décadas, as críticas ao modelo manicomial. Assim, com bases nestes referenciais teóricos, criaram-se os suportes para a psiquiatria de setor francesa, do movimento de desinstitucionalização norte-americano e do movimento de reforma italiano, representado, sobretudo, por Franco Basaglia. Apesar de concordarem quanto à falência do sistema manicomial como instituição terapêutica, estas nações desenvolveram diferentes propostas alternativas de intervenção, sobretudo em função das diferenças dos contextos políticos, sociais e econômicos destas regiões.

GIOVANELLA \& AMARANTE (1994) apontam que o aparato manicomial não se restringe somente ao hospital, mas abrange todas as instituições em que se exercita o isolamento - desde a sociedade, em seus gestos e olhares preconceituosos, ao saber psiquiátrico, em suas práticas discriminatórias. Por isso, tratar da questão da desinstitucionalização torna-se mais do que falar simplesmente de desospitalização, mas sim da necessidade de rever a hierarquia que sustenta relações de poder desiguais e práticas discriminatórias entre os grupos sociais.

Em relação à experiência de reforma psiquiátrica de Trieste, na Itália, BASAGLIA et al. (1994) sugeriu que seu mérito foi o de ter evidenciado as contradições fundamentais da realidade institucional, se propondo a abordá-las no cotidiano das relações dentro da instituição. Assim, não se constituiu como uma comunidade terapêutica apenas em nível ideológico, mas se dispondo a enfrentar e romper com todos os desafios e dificuldades impostos pela desigualdade das relações sociais e das práticas hierárquicas e discriminatórias. Segundo ele,

“...se falta uma luta revolucionária, isto é, uma batalha política no sentido estrito do termo, a equipe curadora não consegue forjar instrumentos para a própria renovação interna: permanece uma equipe burguesa em um mundo burguês" (p.40).

Nesta mesma direção, BARROS (1994) aponta que a "desconstrução, num sentido ampliado, é interminável, pois significa o questionamento das cristalizações institucionais e mentais". Assim, cabe-nos questionar se, ao substituir os antigos 
manicômios por modelos alternativos de assistência psiquiátrica, não derivamos em nova cristalização, assim promovendo a desospitalização ao invés de uma efetiva desinstitucionalização.

Concordamos que a desospitalização deve-se realizar paralelamente a um processo de desinstitucionalização, do qual a saída do paciente do hospital é apenas um dos aspectos. Assim, esta

“... compreende tanto as intervenções de melhoramento manicomial, em seus aspectos clínicos, étnicos, institucionais e sanitários, quanto a criação de alternativas assistenciais extra-hospitalares, a projeção comunitária da assistência e a superação do isolamento em que se encontra não só o hospital como a psiquiatria mesma" (ORGANIZAÇÃO PANAMERICANA DE SAÚDE, 1990, p.10).

Esta organização aponta ainda que, apesar das doenças mentais serem provavelmente a causa de incapacitação mais importante e de tratamento mais custoso em todas as sociedades, segundo sugere informações mundiais, estas não recebem devida atenção às suas políticas de assistência.

Frente a esta realidade, podemos pensar as políticas de reforma nacionais, considerando-se sobretudo o contexto sócio-histórico em que se desenvolveram. Iniciadas seguidamente a um regime ditatorial militar, que nos deixou como legado uma massa de pacientes cronificados a partir da permanência por longos anos nos manicômios, sem receberem a devida assistência terapêutica, estas parecem carecer de recursos para se concretizarem como políticas de "desinstitucionalização". Assim, favorecer políticas de financiamento que visem criações de aparatos de saúde que mantenham um bom nível de atendimento ao paciente torna-se fundamental. Como nos lembra VASCONCELOS (1990),

“...um processo de desinstitucionalização psiquiátrica pode significar a ressocialização e a devolução da loucura à sociedade, mas principalmente no contexto do Terceiro Mundo não deve ingenuamente induzir a uma reprivatização compulsória da loucura na família ou simplesmente um processo de negligência social, em caso de sua ausência" (p.233). 
Nesta direção, CESARINO (1989) nos aponta que por muito tempo vigorou nos serviços ambulatoriais de saúde mental uma estrutura interna rígida, antiga e autoritária, em que predominava como método de trabalho apenas o atendimento médico e medicamentoso, e praticamente não havia a atuação conjunta de outros profissionais. Podemos, então, questionar se ao introduzir sistemas alternativos de assistência ao doente mental, não se acaba repetindo o mesmo processo de exclusão e abandono observado anteriormente nos manicômios, criando-se a cronificação do paciente nos espaços extramurais.

Concordamos com ALVES, SEIDL, SCHICHTMAM \& SILVA (1994) que as proposições de reforma psiquiátrica no Brasil, a partir dos princípios da Reforma Sanitária, têm por objetivos um sistema de saúde igualitário, descentralizado, universal, com os serviços organizados de forma regionalizada e hierarquizada, além da integralidade da atenção e a participação social - fundamentais em uma proposta de resgate da cidadania. A partir disso, entende-se o momento atual como propício para a implementação de reformas efetivas neste campo.

Também devemos considerar que seguidamente às políticas de reforma dos atendimentos em saúde mental e de desospitalização surgiram propostas de novos modelos de assistência psiquiátrica. Entre estas novas possibilidades de atendimento, as práticas grupais se sobressaíram, sendo hoje apontadas como uma das modalidades de tratamento fundamentais nos mais diferentes contextos de atendimento.

Sendo este estudo dirigido a uma compreensão do fenômeno grupal, julgamos relevante apresentar nesta introdução alguns dos caminhos que marcaram o desenvolvimento das práticas de grupo enquanto modalidade de tratamento das patologias mentais, até se constituir hoje como um dos principais recursos de atendimento nos mais variados contextos. 


\section{2- O emprego da psicoterapia de grupo no tratamento das patologias mentais.}

A terapia de grupo, enquanto modalidade orientada e planejada para $\mathrm{o}$ tratamento das patologias, tem origem relativamente recente, no início do século XX.

Segundo nos aponta SCHEIDLINGER (1996) em um artigo sobre a história da psicoterapia de grupo, esta pratica foi iniciada pelo médico Joseph Pratt, em 1905. Em sua prática clínica, reunia grupos de pacientes tuberculosos para palestras informativas, que acabavam extrapolando esta finalidade e promovendo um espaço propício para a troca de experiências entre os pacientes e para um maior envolvimento emocional, assim auxiliando-os no melhor enfrentamento de suas moléstias crônicas.

O emprego das práticas de grupo cresceu nas nove décadas que se seguiram, com o aparecimento de diferentes grupos, inicialmente ligados à educação ou a uma abordagem mais didática, e que foram, de algum modo, precursores do uso deste recurso como uma forma de ajuda, indicando a evolução desta modalidade de atendimento ao longo dos anos (SCHEIDLINGER ,1994).

De acordo com a literatura sobre a história da psicoterapia de grupo, influenciado pela clínica de Pratt, o médico psiquiatra Edward Lazell em 1921 iniciou debates em grupo com pacientes psiquiátricos, orientado por linhas psicanalíticas e por conferências de apoio. Também na década de 20, Trigant Burrow abandonou sua prática psicanalítica individual em favor de debates ao ar livre, que incluíam os pacientes, suas famílias e colegas, e cunhou o termo "análise de grupo", visando estudar em profundidade o comportamento social. L. Cody Marsh, ministro religioso que se tornou psiquiatra, desenvolveu uma abordagem de tratamento em grupo voltada para pacientes internados em 1931. Sua máxima, usualmente referida, apontava que "pela multidão foram eles quebrantados; pela multidão serão curados", assim valorizando a psicoterapia de grupo no tratamento das patologias mentais. (SCHEIDLINGER, 1994).

Ainda segundo este autor, a utilização planejada de pequenos grupos para tratamento teve início mais especificamente na década de 30, tendo como pioneiros os trabalhos de Louis Wender, Paul Schilder, Jacob Levi Moreno, Samuel Slavson, Fritz Redl e Alexander Wolf. 
Wender iniciou sua prática de grupo no tratamento de pacientes internados, depois expandindo-a também para pacientes ambulatoriais, baseando-se em conceitos da "psicologia de grupo" de Freud e utilizando interpretações transferenciais. Com base em uma vertente substancialmente analítica, Schilder, em 1936, apoiava-se, em sua prática clínica, sistematicamente na interpretação dos sonhos e na análise da transferência, sendo considerado o pioneiro da terapia analítica de grupo. A teoria psicodramática e o teatro da espontaneidade de Jacob Levi Moreno ofereceram contribuições importantes à psicoterapia de grupo neste período, bem como Slavon a partir de sua "terapia de grupo da atividade", em que propunha a expressão de fantasias e de sentimentos mediante a ação e o brinquedo. Sua técnica, originalmente dirigida a crianças, foi também posteriormente aplicada a adolescentes e adultos. Ainda nesta década, devemos apontar as contribuições de Alexander Wolf, em sua abordagem freudiana à psicoterapia de grupo, utilizando-se de derivados da associação livre, da transferência, da resistência e da análise dos sonhos. Fritz Redl apud SCHEIDLINGER (1994), por sua vez, é reconhecido por sua utilização de grupos diagnósticos para crianças, e também por propagar esta foram de terapia nos meios psicanalíticos.

A partir da segunda guerra mundial, com o aumento de casos psiquiátricos e a diminuição de profissionais nos serviços de atendimento, a utilização das práticas grupais passou a ser vista como uma necessidade, e diferentes modelos de terapia de grupo passaram a ser utilizados - desde grupos de pacientes internos e similares, a grupos psico-educacionais, de desenvolvimento humano e de auto-ajuda. Neste contexto, vale referir a experiência inglesa (representada por Bion e Rickman) e norte-americana (representada por Menninger). Segundo BIRMAN \& COSTA (1994), Bion e Rickman eram responsáveis pela direção de um hospitalar militar inglês que cuidava de cerca de quinhentos pacientes com diagnósticos de neurose, sendo baixo o número de médicos disponíveis para os tratamentos individuais. A inviabilidade desses atendimentos individuais estimulou uma mudança na estrutura hospitalar, onde o emprego de pequenos grupos, caracterizados por discussões e atividades, passou a ser fundamental para garantir a eficácia dos atendimentos e sua potencialidade terapêutica. A experiência de Menninger nos Estados Unidos baseou- 
se em instrumento de trabalho semelhante, procurando integrar os enfermos em pequenos grupos, o que parecia indicador de altas e curas.

O surgimento, na década de 50, da Associação Americana de Psicoterapia de Grupo, fundada por Slavson, bem como da Sociedade de Psicoterapia de Grupo e Psicodrama, representada por Moreno, favoreceram o crescimento desta prática a partir das décadas seguintes. Por outro lado, a psicoterapia de grupo presenciou a rivalidade entre estas diferentes escolas de pensamento, além do surgimento de novas terapias no campo da saúde mental: análise transacional, terapia centrada na pessoa, Gestalt, terapia cognitiva e terapia existencial, entre outras.

Além disso, a literatura desta década mostra a expansão desta prática a vários contextos clínicos, incluindo "hospitais gerais e psiquiátricos, clínicas ambulatoriais, programas de reabilitação e instituições correcionais", sendo que

“... as populações de pacientes eram amplas em raios de ação, indo de crianças a adultos com distúrbios psiquiátricos variados (inclusive problemas psicossomáticos), homossexuais e mentalmente retardados" (SCHEIDLINGER, 1996, p.06).

A partir disto, alguns estudos vinculando a psicoterapia de grupo à psicanálise enquanto referencial teórico surgiram, bem como discussões sobre aspectos técnicos da prática grupal. Nos últimos vinte anos aumentou a aceitação das diferenças ideológicas entre tais abordagens, o que favoreceu a existência concomitante dos diferentes modelos, e novamente um crescimento sem precedentes dessa modalidade de intervenção.

FUHRIMAN \& BURLINGAME (1994) sugerem que Pratt, Moreno, Marsh, Lazell, Burrow e Adler, entre outros, são atualmente reconhecidos por sua efetiva contribuição nas definições, na teoria e na prática iniciais da psicoterapia de grupo. ZIMERMAN (1997a), por sua vez, situa, entre os grandes teóricos que contribuíram ao longo destes anos para o desenvolvimento desta prática e para o entendimento dos fenômenos e da dinâmica grupais, autores como Pratt /1905, Freud /1910, Moreno / 1930, Levin /1936, Foulkes /1948, Pichón-Rivière e Bion (década de 40), Anzieu e Käes (década de 60), entre outros.

O crescimento destas modalidades de intervenção em grupo, nas décadas subseqüentes, ganhou proporções acentuadas, sendo que "poucos movimentos no 
campo das intervenções em Saúde Mental podem se igualar ao crescimento fenomenal, em menos de um século, que caracterizou a terapia de grupo" (SCHEIDLINGER, 1994, p.217).

O emprego das práticas grupais enquanto modalidade de tratamento das patologias mentais, encontra-se também relacionado às transformações do sistema psiquiátrico - como a progressiva extinção dos manicômios e mudanças nas concepções em Saúde Mental. Conforme afirmamos anteriormente, as primeiras reformas psiquiátricas baseavam-se em noções de que também o paciente psiquiátrico poderia se reabilitar e ingressar no sistema produtivo, assim surgindo as primeiras propostas visando a transformação do espaço hospitalar em um espaço terapêutico, entendido enquanto local de reabilitação à vida em sociedade. Nesta perspectiva, o tratamento do doente mental passava a ser orientado de modo que

"as normas e limites que devem regular e delinear a vida dos pacientes no interior do hospital são uma síntese das regras da vida social mais ampla, que devem ser internalizadas pelos pacientes, e a cura estaria relacionada com esta possibilidade de reabilitação" (BIRMAN \& COSTA, 1994).

De acordo com estes autores, este entendimento sobre a forma de tratamento do doente conduz à introdução e à ampliação do trabalho em grupos nos hospitais, como os grupos operativos, recreativos, artísticos e terapêuticos propriamente ditos. O emprego dessas práticas neste contexto norteava-se pela concepção de que o grupo pode servir como educação para a vida em sociedade, já que este se constitui como o núcleo da vida social no espaço extra-hospitalar. Assim, esta nova proposta de atendimento corresponde também a uma mudança no objeto de estudo da psiquiatria, que deixa de ser a doença e passa a ser a Saúde Mental, compreendida em termos de adaptação social. Além disso, outro aspecto que já se constituía como relevante era a busca de uma maior produtividade do terapeuta e de uma melhor relação custobenefício em comparação com as demais formas de psicoterapia.

Especificamente no contexto brasileiro, a psicoterapia de grupo teve seu crescimento impulsionado sobretudo pelas mudanças nas concepções de Saúde Mental, originadas a partir dos movimentos de reforma psiquiátrica que visavam a reintegração social do paciente. A redução do número de internações em hospitais 
psiquiátricos e a conseqüente criação de políticas orientando novas formas de atendimento para esta população, como por exemplo, a expansão dos hospitais-dia, e os atendimentos ambulatoriais nos centros de saúde - substituindo atendimentos que até então eram realizados com o paciente separado do convívio social - vieram a transformar o atendimento em grupo no principal recurso terapêutico nestes contextos (LANCETTI, 1993).

Portanto, podemos concluir que as mudanças nas formas tradicionais de atendimento acolheram as intervenções em grupo como um meio adequado para tratamento de pacientes psiquiátricos. Se, anteriormente, os doentes mentais viviam a realidade da exclusão social e da limitação de suas interações com os outros em função de seu isolamento nos hospitais psiquiátricos, as políticas atuais buscam resgatar o direito destes pacientes a estarem em sociedade. E, neste sentido, o tratamento em grupo pode propiciar formas de se perceberem em interação e de "aprender melhor a se relacionar com os outros" (VINOGRADOV \& YALOM, 1992; p.168). Como afirmou CONTEL (1997) "aprende-se melhor, no grupo, a graduar-se a distância e a intimidade com as pessoas, em especial com psicóticos, que estão a confundir mundo interno e mundo externo" (p.277).

Em um estudo sobre o tratamento de pacientes psicóticos em grupo, CALIL, SILVA \& SAKURAY (1993) afirmaram que a psicoterapia de grupo no Brasil "tem se mostrado viável para nossa realidade sócio-econômica, com redução do número de internações e dos custos econômicos e emocionais decorrentes destas” (p.540). Há praticamente unanimidade nos relatos da literatura mundial em relação a esta viabilidade - dada a existência real de vantagens de custo na introdução desta modalidade de tratamento como forma de dar conta da demanda sempre crescente de pessoas buscando ajuda no campo da Saúde Mental (ENGEL, 1983; SCHEIDLINGER, 1994; ROSEMBERG \& ZIMET, 1995; ZIMERMAN, OSÓRIO et al., 1997).

Vários estudos referem a utilização de tratamento em grupo em diferentes contextos e com diferentes finalidades, segundo nos sugere revisão bibliográfica sobre o tema. No contexto brasileiro, ZIMERMAN, OSÓRIO et al.(1997) apresentaram trabalhos com grupos, em diferentes contextos e abordagens teóricas, referindo o valor desse modelo de intervenção como forma de ajuda. 
Tanto os estudos como os relatos da utilização da técnica grupal confirmam a grande expansão da psicoterapia de grupo, e nos faz concordar com ROSEMBERG \& ZIMET (1995) de que parece haver "pouca dúvida de que a psicoterapia de grupo se tornará a mais importante modalidade de tratamento nos mais importantes locais de ajuda, nos anos que virão" (p.379).

Considerando este acentuado crescimento, diversas práticas de grupo vêm sendo utilizadas nos mais variados contextos. Apesar disso, suas definições permanecem imprecisas e pouco esclarecedoras da natureza destes grupos e de seus limites e possibilidades. A fim de melhor delimitar o campo deste estudo, abordaremos no item seguinte a diversidade presente na prática da psicoterapia de grupo e alguns indicadores de sua eficácia.

\section{3- A diversidade das práticas psicoterápicas em grupo}

Atualmente, a psicoterapia de grupo expandiu-se a várias áreas, existindo hoje grupos distintos, em diferentes contextos, com diferentes objetivos, focos, duração, constituições e orientações terapêuticas. No contexto local, ZIMERMAN (1997a) aponta que

\footnotetext{
"na atualidade, há no Brasil uma série de pessoas em diversas e múltiplas áreas trabalhando ativamente em busca de novos caminhos e de uma assistência mais ampla e abrangente com a aplicação dos recursos da dinâmica grupal" (p.26).
}

Apesar da grande expansão das práticas grupais, existe grande confusão conceitual nas definições destes diferentes grupos realizados, sendo que apenas a nomeação de um determinado grupo nos permite saber pouco sobre sua natureza e seu modo de funcionamento.

Influenciada originalmente por diversas conceituações teóricas e práticas, a psicoterapia de grupo encontra-se hoje em um campo de difícil delimitação. Segundo FUHRIMAM \& BURLINGAME (1994) traços da psicanálise, da dinâmica de grupo, 
do existencialismo, e de teorias comportamentais podem ser encontrados hoje no modo como as terapias de grupo são definidas, conceitualizadas, implementadas e avaliadas em seus resultados. Além disso, esta prática contém também a influência de múltiplas disciplinas, incluindo a psiquiatria, a psicologia, a educação, a sociologia, entre outras, o que contribui para a dificuldade existente na delimitação do campo da psicoterapia de grupo.

Segundo ISHARA (1996), "os modelos de tratamento em psicoterapia de grupo são muitos, refletindo a diversidade das aplicações clínicas e a variabilidade de escolas e pensamentos em psiquiatria" (p.10). Em conseqüência desta variedade de modelos, que envolve um conjunto variado de proposições teóricas e práticas clínicas, torna-se necessário que as experiências em grupo sejam adequadamente descritas para que se possa discriminar suas especificidades.

Tendo em vista a dificuldade existente na conceituação dos grupos, DIES (1992) aponta que dizer que se faz um grupo de apoio, psicoterápico ou psicoeducativo, por exemplo, é pouco quando não se tem clareza dos critérios utilizados para conceituá-los de uma ou outra forma. Assim, torna-se fundamental a compreensão da natureza dos grupos estudados, para além de suas denominações, para um entendimento sobre as possibilidades e limites terapêuticos destas diferentes modalidades de tratamento em grupo.

De acordo com VINOGRADOV \& YALOM (1992), uma possível forma de diferenciação dos grupos existentes é quanto ao tipo de paciente que deles fará parte. Grupos para pacientes internados terão características, settings, orientações diferentes de grupos para pacientes ambulatoriais. Estes, por sua vez, também estarão "variando imensamente em suas situações clínicas, objetivos e uso das várias técnicas" (p.172). Estes autores sugeriram uma classificação dos grupos ambulatoriais, baseados nos objetivos ou motivações do grupo, em quatro principais subdivisões, a saber: 1) grupos de orientação interpessoal e dinâmica; 2) grupos de orientação comportamental e educacional; 3) grupos de apoio; e 4) grupos de manutenção e reabilitação. Porém, ressaltam que "embora esta classificação sirva a uma função heurística e nosológica, existe uma grande superposição nos objetivos entre os vários tipos de grupos para pacientes ambulatoriais" (p.172) 
ZIMERMAN (1997a), por outro lado, aponta para a necessidade de uma primeira grande divisão, separando os grandes grupos (macro-sociologia) dos pequenos grupos (micro psicologia). Refere que

“...é válido partir do princípio de que, virtualmente, a essência dos fenômenos grupais é a mesma em qualquer tipo de grupo, e o que determina óbvias diferenças entre os distintos grupos é a finalidade para a qual eles foram criados ou compostos" (ZIMERMAN, 1997b, p.75).

Neste sentido, considerando como critério a distinção quanto às diferentes finalidades com que um determinado grupo é criado, propõe a divisão genérica dos pequenos grupos, em dois grandes ramos: os grupos operativos e os grupos psicoterápicos. Assim, independentemente do modo como se categorize as diferentes práticas existentes em grupo, é relevante que se considere a diferença de objetivos / focos de cada uma delas, pois nem todos os grupos existentes têm finalidades claramente terapêuticas e nem se constituem enquanto grupos psicoterápicos.

OSÓRIO (1997) chamou a atenção para o fato de que

“... o ponto fundamental na dinâmica grupal é a interação, e é sobre esta que temos que focar nosso interesse especulativo, independentemente do vértice teórico sob o qual nos posicionamos para compreender tanto os aspectos construtivos como os obstrutivos da atividade grupal dos indivíduos" (p.69).

Este aspecto é reforçado pela noção de que grupos são realizados em diversas linhas teóricas e estudos apontam para resultados positivos em grande parte deles, o que nos leva à conclusão de que existe no grupo algo maior (a interação), que é independente da abordagem teórica e da técnica utilizada.

SCHEIDLINGER (1994) também verificou, em relação ao pluralismo de teorias e enfoques na área, que "praticantes experientes, apesar de suas divergentes teorias, atingiram resultados parecidos" (p.222). WHEELAN \& HOCHBERGER (1996) revisando a literatura também verificaram que, apesar das diferenças de objetivos e do tempo em que diferentes grupos foram estudados, há muito mais semelhanças do que diferenças no que tange ao que já pôde ser descrito em relação ao desenvolvimento e processo de grupo. 
Segundo VINOGRADOV \& YALOM (1992), resultados de múltiplos estudos testaram a eficácia do tratamento em grupo para uma ampla faixa de problemas psicológicos e transtornos comportamentais, desde o comportamento interpessoal neurótico até a sociopatia, abuso de substâncias e doença mental crônica, sustentando assim o consenso clínico quanto ao benefício da psicoterapia de grupo.

Assim, embora tenhamos apontado que o fator econômico foi e continua sendo responsável pelo grande impulso dado à psicoterapia de grupo, devemos ressaltar que esta encontra, em sua base teórica, aspectos que a sustentam enquanto um modelo de intervenção terapêutica adequado e eficaz. Neste sentido, VINOGRADOV \& YALOM (1992) afirmam que

"...embora a terapia de grupo seja mais efetiva em termos de custos, suas vantagens transcendem as considerações meramente econômicas; ela é uma forma de tratamento que faz uso de propriedades terapêuticas únicas não compartilhadas por outras espécies de psicoterapias. A terapia de grupo é um modelo incomparável de psicoterapia porque se baseia em um instrumento muito poderoso: o setting de grupo. O poder deste instrumento deriva-se da importância exercida pelas interações pessoais sobre nosso desenvolvimento psicológico” (p.12).

Estes autores baseiam-se na premissa de que a personalidade e os padrões de comportamento podem ser vistos como o resultado das interações iniciais com outras pessoas significativas, segundo originalmente proposto pelo psiquiatra Sullivan apud VINOGRADOV \& YALOM (1992). Assim, a psicopatologia estaria relacionada a uma história de relacionamentos distorcidos ao longo do desenvolvimento humano, podendo ser tratada buscando-se a correção destas distorções interpessoais.

ZIMERMAN (1997a), por sua vez, afirma que "o ser humano é gregário por natureza e somente existe, ou subsiste, em função de seus relacionamentos interpessoais", participando desde o seu nascimento em diferentes grupos que o auxiliam na constituição de sua identidade individual. Para Guatari apud LANCETTI (1993) "o homem se tornou homem em grupo e a produção de subjetividade não se pode entender sem os processos coletivos serem considerados como componentes da subjetivação" (p.161).

Assim, apesar das especificidades existentes nas várias abordagens teóricas e práticas orientadas para o entendimento da origem da patologia mental, parece ser 
relativamente consensual que o ser humano se constitui enquanto um ser em interação, sendo o grupo algo inerente à sua própria natureza. Deste modo, o grupo pode ser entendido como um espaço adequado para a exploração da subjetividade, por funcionar como um "laboratório social" no qual os membros reproduzem os papéis que ocupam no dia-a-dia de suas interações (VINOGRADOV \& YALOM, 1992; AGAPETUS, 1994; ZIMERMAN, OSÓRIO et al., 1997), ao mesmo tempo em que oferece ao indivíduo a possibilidade de se pensar enquanto ser em interação, de refletir sobre seu papel no grupo e nos demais grupos sociais de que faz parte.

Nesta perspectiva, o grupo pode constituir-se enquanto um espaço terapêutico por várias razões: porque possibilita a identificação entre os membros, promovendo "neo-identificações" mais sadias e que favorecem a construção de um sentimento de identidade; porque funciona como um continente de angústias, porque é um espaço em que cabe a existência conjunta da igualdade e da diferença; porque oferece ao indivíduo a possibilidade de reparação; porque atribui-se importância à realidade atual e ao sofrimento psíquico de seus membros; enfim, porque valoriza a capacidade de socialização (ZIMERMAN, 1997c). Ou ainda, como apontaram VINOGRADOV \&YALOM (1992), porque atuam no grupo determinados fatores terapêticos que ajudam o indivíduo em sua tomada de consciência de si mesmo como ser social.

Esta diversidade de possibilidades terapêuticas deve ser especificamente considerada em cada grupo, considerando-se os objetivos e a orientação terapêutica sob o qual foi originalmente proposto.

Tendo apontado aspectos favoráveis à terapia de grupo como modalidade de tratamento em saúde mental, devemos ressaltar que, como qualquer modelo de intervenção terapêutica, a psicoterapia de grupo também tem restrições, o que nos alerta para alguns cuidados quanto a sua utilização indiscriminada. Pensamos ser de fundamental importância que a admissão de formas de atendimento em grupo seja coerente com as reais necessidades de cada paciente, de modo a ser um recurso de atendimento em Saúde Mental que realmente possa trazer benefícios aos seus usuários.

A literatura é vasta em apontamentos sobre a necessidade de cuidados de seleção dos pacientes para a composição dos grupos, havendo estudos que versam sobre critérios de seleção (inclusão e exclusão) de pacientes nos mais variados 
grupos e em diferentes contextos, considerando-se por um lado, suas características individuais, seus diagnósticos ou seu funcionamento psicodinâmico, e por outro, a própria finalidade do grupo a ser constituído e sua orientação terapêutica (VINOGRADOV \& YALOM, 1992; KLEIN, 1996; BUDMAN, SIMEONE, REILLY \& DEMBY, 1994; ROSEMBERG \& ZIMET, 1995; SALVENDY, 1996; ZIMERMAN \& OSÓRIO, 1997;).

Segundo SALVENDY (1996), estudos presumem que uma seleção adequada de pacientes para o grupo reduz o índice de abandono no tratamento, além de contribuir para o desenvolvimento da coesão grupal, fundamental no estabelecimento de comportamentos no grupo favoráveis à mudança. Porém, refere que embora haja indicações empíricas respeitáveis, não se dispõe de métodos confiáveis para predizer com certeza como será o comportamento de um paciente ao final do tratamento. Para aliviar este nível de incerteza, alerta para a necessidade de que se ofereça ao paciente um grupo mais adequado a seu problema, e não um grupo que o terapeuta tenha disponível.

Entre os critérios de inclusão Yalom apud SALVENDY (1996) refere que "o critério isolado mais importante de seleção para qualquer grupo é a capacidade que o paciente tem de desempenhar a tarefa do grupo" (p.65).

Indicações específicas à psicoterapia de grupo são referidas por SALVENDY (1996), que também situa alguns critérios considerados como de exclusão na constituição de grupos para adultos em tratamento ambulatorial de orientação psicodinâmica, e que teriam sido também referidos por outros autores, como por exemplo: pessoas que não tolerariam o setting grupal ou que não aceitariam as regras do grupo; que não têm interesse pelos outros; que são demasiadamente autocentrados; pacientes com baixa inteligência ou organicidade ou domínio insuficiente da linguagem; pacientes agudamente ansiosos, maníacos, psicóticos ou suicidas, entre outros. Outros aspectos, tais como a duração do grupo, a homogeneidade ou heterogeneidade do mesmo, também devem ser considerados na formação de qualquer grupo de terapia específico, considerando-se fundamentalmente seus objetivos e finalidades terapêuticas.

Segundo VINOGRADOV \& YALOM (1992), existem três características flexíveis nos grupos de terapia: o contexto, seus objetivos e a estrutura de tempo que 
os organiza. Tais aspectos devem ser considerados na composição de qualquer grupo, pois influenciam diretamente nas finalidades do grupo e no uso de uma determinada técnica ou orientação terapêutica.

Pode-se entender a psicoterapia de grupo como a aplicação de técnicas a um grupo de pacientes, em que o próprio grupo, bem como as intervenções específicas de seu terapeuta, facilitam a mudança, o que dá à psicoterapia de grupo seu potencial terapêutico singular. Concordamos com VINOGRADOV \& YALOM (1992) que

"o poder da psicoterapia de grupo reside na sua adaptabilidade: ela é um modo flexível e eficiente de psicoterapia que pode incluir uma ampla faixa de contextos, objetivos e pacientes" (p.208).

Considerando que este estudo visa compreender a natureza de um grupo apoio e de tempo limitado, no item seguinte teceremos algumas considerações acerca das particularidades dos grupos assim denominados, segundo revisão da literatura sobre o tema.

1.4- Grupos de curta duração e grupos de apoio: especificidades destas intervenções

Entre as diferentes modalidades de psicoterapia de grupo, os grupos de curta duração destacam-se por seu acentuado crescimento nos últimos tempos. SCHEIDLINGER (1994) observou, em sua revisão de literatura, que

“... os antigos grupos psicanalíticos, que enfatizavam a reestruturação intrapsíquica em longos períodos de tempo, renderam-se a modalidades de tratamento breve, enfocando objetivos mais específicos, como melhorar o funcionamento egóico e a competência social" (p.219).

Assim, o aumento no emprego das modalidades de grupo em curto prazo, orientadas para crises e em grande parte apoiadoras, sugerem a possibilidade de que esta prática se torne mais popular de que as formas de psicoterapia reconstrutivas em longo prazo (SCHEIDLINGER, 1996). 
Um dos fatores que contribuíram para o crescente emprego de grupos de tempo limitado ou de curta duração foi o fator econômico, que determinou e ainda determina a necessidade de reduzir custos e aumentar a oferta de atendimento no contexto da saúde mental. Contudo, além da influência deste fator, estudos demonstram a efetividade destes grupos de curta duração, atentando para aspectos terapêuticos próprios desta prática e que viabilizam e justificam seu emprego nos mais variados contextos clínicos (BUDMAN et al., 1994).

Segundo nos sugere MACKENZIE (1996), a psicoterapia de grupo de tempo limitado utiliza muitas técnicas em comum com a psicoterapia de grupo em geral, mas "sua unicidade reside no uso proposital do tempo para acelerar e concentrar o processo terapêutico" (p.47). Assim, o grupo e seus membros têm a possibilidade de se desenvolver psicologicamente nesta estrutura de tempo, sendo que o processo do grupo pode se concentrar em temas fundamentais a partir do conhecimento de que o tratamento tem um tempo limitado (MACKENZIE, 1999a; MACKENZIE, 1999b).

Em relação a duração destes tratamentos, a literatura aponta que esta deve ser determinada de acordo os objetivos da intervenção. ROSEMBERG \& ZIMET (1995), revisando a literatura sobre grupos de tempo limitado, encontraram que estes usualmente variam entre 2 a 24 sessões. KLEIN (1996) aponta que em média, estes grupos duram de 12 a 15 sessões.

Parece consenso, contudo, que o sucesso de uma terapia de curto prazo reside na postulação de objetivos específicos que possam ser executados e alcançados por seus membros durante o tratamento (VINOGRADOV \& YALOM, 1992; BUDMAN et al., 1994; ROSEMBERG \& ZIMET, 1995; KLEIN, 1996; MACKENZIE, 1996; MACKENZIE, 1999b; MACKENZIE, 1999c; MACKENZIE, 1999d).

BUDMAN et al. (1994) apontam que muitos autores encontram em suas revisões de literatura, dados que evidenciavam que muitas vezes a redução do tempo do tratamento não era vinculada à uma correspondente mudança nos objetivos, assim mascarando a prática psicoterápica em grupos de tempo limitado. Assim, ao terminar um determinado grupo, muitos pacientes precisavam ser re-encaminhados a outros grupos ou outras formas de tratamento, o que na verdade acabava por estender ainda mais a duração do processo terapêutico. 
Estes autores sugerem que ao invés de se trabalhar com o conceito de cura, muitas vezes presentes em tratamentos de longa duração, os grupos de tempo limitado devem postular objetivos terapêuticos mais específicos, realísticos e acessíveis. Poey apud BUDMAN et al. (1994) aponta a necessidade de que estes grupos trabalhem mais em nível de oferecimento de apoio do que de tentativas de mudança nos mecanismos de defesa dos pacientes, ou seja, atuando mais em nível de processo secundário. Para ele, este tipo de intervenção favorece que o paciente tenha ganhos significativos em muitas áreas, incluindo o alívio de sintomas, o restabelecimento do equilíbrio psicológico, maior conforto em suas relações interpessoais e aumento no auto-entendimento.

Também para ROSEMBERG \& ZIMET (1995), os objetivos da psicoterapia de grupo de curta duração diferem dos objetivos dos tratamentos de longa duração. Enquanto estes têm seus objetivos voltados para mudanças de caráter, a psicoterapia em grupos de tempo limitado focaliza-se nas capacidades individuais e nos aspectos saudáveis da personalidade do paciente, favorecendo seu desenvolvimento.

De acordo com KLEIN (1996), a revisão da literatura sugere que

“os objetivos dos grupos terapêuticos de curta duração são consistentes com os de outras formas de psicoterapia, incluindo: 1) a melhora da aflição (isto é, a redução do desconforto sintomático); 2) o pronto restabelecimento do equilíbrio emocional anterior do paciente; a promoção do uso eficaz dos recursos do paciente (por exemplo: aumentar seu senso de controle e domínio, dar ênfase à adaptação, proporcionar reestruturação cognitiva e auxiliar a mudança comportamental, a auto-ajuda e a eficácia social); e 4) o desenvolvimento da compreensão, pelo paciente, do distúrbio atual e o aumento de suas habilidades de enfrentamento para o futuro" (p.216).

Além da necessidade de que os objetivos deste tipo de intervenção sejam cuidadosamente articulados às possibilidades oferecidas por uma psicoterapia de tempo limitado, outros aspectos devem ser considerados, entre eles, a seleção dos membros e a composição do grupo, e o manejo e a orientação terapêutica deste. Há indicativos também de que uma preparação do paciente antes de sua participação no grupo pode colaborar em seu engajamento no processo terapêutico.

Em relação à composição do grupo, os pacientes devem ser selecionados com base em suas reais capacidades de se beneficiar de um formato de grupo em tempo 
limitado. Neste sentido, o processo de engajamento e coesão nestes grupos é acelerado pela composição de um grupo com bases em diagnósticos clínicos e problemas ou situações interpessoais similares (MACKENZIE, 1996; MACKENZIE, 1999c; MACKENZIE, 1999d). Esta relativa homogeneidade também é enfatizada por outros autores como fundamental para o mais rápido estabelecimento da coesão grupal e, conseqüentemente, desenvolvimento do grupo (VINOGRADOV \& YALOM, 1992; BUDMAN et al., 1994; SALVENDY, 1996; ROSEMBERG \& ZIMET, 1995; KLEIN, 1996).

Assim, segundo SALVENDY (1996) os grupos homogêneos oferecem vantagens quando a ênfase terapêutica recai no apoio ou no alívio sintomático, geralmente sendo indicados para pacientes com queixas monossintomáticas. Segundo este autor, os grupos homogêneos apresentam menos conflitos e podem, portanto, propiciar um alívio mais rápido dos sintomas. Neste sentido, BUDMAN et al. (1994) enfatizam que a experiência clínica indica a homogeneidade e o foco como importantes na maioria das terapias de grupo de curta duração, pois constituem aspectos que favorecem aos membros se perceberem com características, problemas e/ou conflitos em comum, assim impulsionando uma mais rápida coesão grupal. E, segundo este autor, esta tem sido relacionada a melhores resultados. Para eles, a possibilidade de que os pacientes se sintam compartilhando problemas similares é relevante, e é facilitada quando se trabalha em grupos orientados por um determinado foco.

Assim, segundo nos refere KLEIN (1996), os grupos homogêneos parecem partilhar de "um senso de comunidade e oferecem a seus membros considerável apoio e autovalidação" (p.220). Segundo a literatura sobre o tema, estes grupos fornecem coesão e aglutinação grupais mais imediatas, além de oferecerem mais apoio e proporcionarem um maior alívio sintomático. Yalom apud KLEIN (1996) refere que grupos homogêneos

"tendem a manter a interação em um nível um tanto mais superficial que os heterogêneos e oferecem menos oportunidades de resolver transferências múltiplas e engajar-se num texto amplo da realidade, uma vez que a gama de interação, indagação e auto-revelação neles são muito mais limitadas do que nos grupos heterogêneos" (p.220). 
Este autor alerta, contudo, que ao se abordar a questão da homogeneidade deve-se ter em mente que esta é sempre relativa a algumas características dos pacientes, especificamente selecionadas com base em critérios anteriormente estabelecidos pelo coordenador do grupo. Assim, certa diversidade sempre estará presente nos grupos, e a homogeneidade, nesta perspectiva, é construída pelo coordenador do grupo no momento de sua composição, estando intrinsecamente relacionada aos objetivos com que o grupo foi proposto.

A literatura também refere a importância de que o tratamento em grupos de curta duração tenham um foco que o oriente. Este aspecto está intimamente relacionado à postura assumida pelo terapeuta em seu modelo de coordenação. Segundo BUDMAN et al. (1994),

“.... assim como manter um foco na psicoterapia de curta duração é central, é também imperativo que o terapeuta entenda o foco apenas como um instrumento para conceituar e organizar o grupo, e não como uma realidade rígida" (...) "ter um foco conduz o líder a trazer para o grupo um conjunto de indivíduos que compartilhem de uma certa similaridade quanto a uma questão ou um conjunto de questões" (p.326).

Quanto à postura terapêutica do coordenador de grupos de tempo limitado, atitudes diretivas, apoiadoras e ativas têm se mostrado bastante favoráveis no desenvolvimento destes grupos. Muitas vezes, o oferecimento de conselhos, tarefas e a utilização de recursos extra-grupais têm sido empregados com êxito neste tipo de tratamento (BUDMAN et al., 1994; KLEIN, 1996; MACKENZIE; 1996, entre outros).

De acordo com MACKENZIE (1996) num grupo de tempo limitado o terapeuta deve ser tão ativo quanto necessário para manter a atenção dos membros na temática do grupo e nos objetivos do tratamento. Isto não significa que o terapeuta controla o processo do grupo, mas sim que este tem como função manter o foco temático e encorajar a participação ativa de todos os membros, sendo que grande parte deste trabalho pode ser feita por intervenções de reforço e encorajamento.

Assim, neste tipo de grupo "pode ser necessário que resistências sejam contornadas, antes que elaboradas, e buscas que se afastem da tarefa grupal precisem ser identificadas e redirigidas", muitas vezes a partir de um maior emprego de intervenções apoiadoras (KLEIN, 1996, p.221). 
Comumente, ao abordar os grupos de curta duração, a literatura refere de modo associado os grupos de apoio. De fato, parece haver pouca clareza no modo como estes grupos são definidos, muitas vezes sendo delimitados em função das intervenções de apoio do coordenador ou dos próprios membros do grupo. Naturalmente, nem todos os grupos homogêneos ou de curta duração constituem-se enquanto grupos de apoio, porém tanto a homogeneidade como a duração (tempo limitado) nestes grupos parecem também estar associadas a esta modalidade de intervenção.

A revisão da literatura na área evidencia a falta de consenso sobre o que são "grupos de apoio". Muitas vezes, as classificações das diferentes modalidades de intervenção em grupo se sobrepõem, o que dificulta uma definição mais exata e uma melhor descrição das especificidades desta forma de tratamento.

Segundo SCHOPLER \& GALINSKY (1993), os grupos de apoio têm a função de ajudar as pessoas a lidarem com estresses relacionados a situações de crises comuns, a transições de vida e em fases de dificuldades econômicas. Estes autores apontam que a proliferação destes grupos também está relacionada à necessidade crescente de apoio determinada pelas rápidas mudanças sociais, que aumentaram a vivência de situações emocionais estressantes. Assim, o termo grupo de apoio geralmente significa o encontro de indivíduos com problemas semelhantes e que estão dispostos a compartilhar de suas experiências pessoais e a se engajarem no desenvolvimento de um processo coeso e suportivo. Uma possibilidade apontada por estes autores é a de que os grupos de apoio sejam concebidos dentro de um contínuo em que também se localizam os grupos de tratamento mais específicos e os grupos de auto-ajuda. Porém, muitas vezes estes grupos guardam similaridades quanto aos aspectos que os determinam, assim havendo uma sobreposição entre suas definições.

Ainda assim, pode-se apontar algumas características próprias dos grupos de apoio. Geralmente estes grupos são centrados em seus membros, ainda que haja distinções entre os papéis dos diferentes participantes. O líder pode ser um profissional, um voluntário ou um dos membros do grupo, e sua autoridade é divida com os participantes. Espera-se, nestes grupos, que os membros assumam papéis ativos ao compartilharem suas experiências, oferecendo informações, conselhos e estimulando a participação de outros membros. As intervenções do coordenador 
tendem a ser variadas, embora seja usual que a discussão não seja estruturada, e que não se centre em interpretações sobre fatores psicológicos. Assim, neste tipo de intervenção almeja-se que o grupo se torne um espaço suportivo e favorável ao envolvimento emocional de seus membros, assim favorecendo o desenvolvimento de suas próprias capacidades e o fortalecimento de suas defesas.

Entre alguns dos efeitos positivos frequientemente referidos por participantes de grupos de apoio encontram-se: melhora em seus recursos sociais, aumento em seu nível de conhecimento sobre as questões que compartilham com o grupo, senso de alívio e reasseguramento, maior capacidade de enfrentamento das situações de vida, melhora na auto-confiança, diminuição do medo e da ambigüidade, alívio emocional, redução da desesperança e melhora em suas condições de exercer atividades apropriadas a suas condições, entre outros (SCHOPLER \& GALINSKY, 1993).

Entre alguns aspectos negativos que podem ser experimentados nos grupos de apoio, Shumaker \& Brownell apud SCHOPLER \& GALINSKY (1993) notaram em seu estudo certa pressão em se conformar, estresse relacionado a pressões do grupo, sentimentos de inadequação e aprendizagem de respostas inadequadas. Porém, aspectos negativos têm sido pouco investigados nos estudos dos grupos de apoio e nos grupos psicoterápicos em geral.

VINOGRADOV \& YALOM (1992) também fazem referência aos grupos de apoio como uma das possíveis formas de atendimento a pacientes ambulatoriais. Como exemplos destes grupos, referem os grupos para enlutados ou outras crises vitais (evolutivas ou acidentais) e grupos de apoio para profissionais. Assim, como grupos de problemas médicos específicos, "os grupos de apoio reduzem o medo, a ansiedade e o isolamento relativos a uma situação particular através dos mecanismos de universalidade e aprendizagem por substituição" (VINOGRADOV \& YALOM, 1992, p.190), propiciando e encorajando o desenvolvimento de novas formas de enfrentamento das situações difíceis e novas estratégias de comportamento. Deste modo, os grupos de apoio têm uma composição homogênea, sendo organizados em torno de membros que compartilham sintomas e problemas de vida comuns. Segundo estes autores, nos grupos de apoio o terapeuta, além de ajudar os membros a confrontarem o que é mal adaptado ou patológico no comportamento um dos outros, 
ele atua favorecendo o apoio e a valorização das capacidades positivas entre os pacientes.

KLEIN (1996), por sua vez, refere intervenções que considera de apoio no contexto de tratamento a pacientes gravemente transtornados, ou para pacientes internados ou que se reúnem após o tratamento. Afirma, assim, que no contexto destes grupos, uma postura de apoio seria mais recomendável, definida por seus objetivos mais circunscritos, enfocados, sobretudo no alívio sintomático e não implicando em elaboração de dificuldades neuróticas que visem alcançar mudanças estruturais de personalidade. Assim, num grupo dessa natureza

“... o terapeuta adota uma postura de aceitação, de apoio, geralmente não interpretativa, na qual pode oferecer conselhos, confrontar o comportamento de seus membros e identificar alternativas comportamentais" (p.221).

Assim, considerando-se estas referências sobre grupos de apoio, percebe-se que estudos têm demonstrado sua aplicabilidade a vários contextos e grupos de pacientes, porém sendo comum a preservação, na formação destes grupos, de uma composição homogênea e de uma orientação terapêutica mais ativa e acolhedora por parte de seus coordenadores.

Tendo em vista a grande proliferação dos mais variados grupos a contextos psiquiátricos, clínicos (hospitais gerais), e comunitários (grupos de auto-ajuda, por exemplo), a indicação de um determinado paciente para a participação em um grupo deve ser acompanhada de uma adequada orientação a respeito de seus objetivos e da forma como este é estruturado e conduzido.

Para facilitar o engajamento dos pacientes no processo psicoterapêutico, a literatura tem apontado para a efetiva contribuição da preparação prévia do paciente, em grupos ou entrevistas que trabalhem suas motivações, esclareça os objetivos do tratamento, sane algumas dúvidas e diminua o temor e ansiedade frente a este tipo de intervenção. Segundo KLEIN (1996), "um processo de preparação claro e refletido ajuda o paciente a desenvolver uma situação positiva e realista que facilita o tratamento" (p.220).

Este procedimento deve, assim, também se estender aos grupos de curta duração ou de apoio, de modo que o paciente torne-se consciente das possibilidades 
que lhe são oferecidas por esta modalidade de tratamento e possa se organizar psicologicamente considerando esta estrutura de tempo oferecida.

Assim, podemos concluir que a prática clínica e a revisão empírica sobre os grupos de curta duração são indicativas do valor potencial desta forma de tratamento. A observação de alguns aspectos pode contribuir para o melhor desenvolvimento destes grupos, entre eles, uma abordagem terapêutica adequada, posturas mais ativas por parte do coordenador e o estabelecimento de focos e de objetivos bem definidos para o tratamento. Além destes aspectos, o sucesso de um atendimento de curta duração requer objetivos adequados a uma intervenção em tempo limitado.

A partir destas noções gerais sobre a prática grupal, sobre sua diversidade, e sobre algumas particularidades dos grupos de apoio e de curta duração, abordaremos a psicoterapia de grupo enquanto objeto de pesquisa. Para tanto, situaremos algumas das possibilidades de investigação do fenômeno grupal, porém focalizando nossa atenção sobre o referencial teórico-metodológico dos fatores terapêuticos, por ter sido este o modelo de pesquisa adotado em parte de nosso estudo.

I.5- A pesquisa em psicoterapia de grupo e o referencial teórico-metodológico dos fatores terapêuticos

Apesar do desenvolvimento da psicoterapia de grupo ter se dado em um espaço de tempo relativamente pequeno, devemos concordar com SCHEIDLINGER (1994) que a pesquisa neste campo atrasou-se em relação à difusão da prática desta modalidade de atendimento. Talvez, esta escassez relativa de pesquisa na área ocorra em razão da real dificuldade de se proceder um estudo que contemple todas as variáveis que influenciam o processo grupal, possibilitando uma melhor compreensão do desenvolvimento do grupo e do campo grupal propriamente dito.

Em termos de pesquisa nesta área, a literatura revela tentativas de pesquisadores em construir instrumentos que possam mensurar, de alguma forma, variáveis que sejam indicativas do processo grupal. Daí a existência de emprego de escalas e/ou questionários que permitam uma visão mais sistematizada sobre este 
fenômeno ou sobre resultados que possam ser atribuídos e relacionados ao processo experienciado no grupo (KIVLIGHAN \& GOLDFINE,1991; LIMA, PONDÉ, AZEVEDO, CARVALHO \& GUIMARÃES,1993; SOLDZ, BUDMAN, DAVIS \& DEMBY, 1993; MATON, 1993; SHAUGHNESSY \& KIVLIGHAN, 1995; WHEELAN \& HOCHBERGER, 1996).

Uma outra linha de estudos neste campo refere a percepção dos autores sobre o tratamento em grupo como um método eficaz de atendimento psicoterápico, tendo por base sobretudo a percepção individual dos pacientes e/ou a evolução de temas ao longo das sessões (ENGEL, 1983; CALIL et al., 1993; O’BRIEN, 1994), ou ainda a observação sistemática do grupo e de seus pacientes (ISHARA, 1996).

Também o emprego da escala dos fatores terapêuticos, proposta por Yalom em 1970 (VINOGRADOV \& YALOM, 1992), tem sido amplamente referido como forma de se proceder uma investigação do processo grupal, seja em sua forma original, seja em revisões posteriormente efetuadas por outros autores.

O esquema de categorização de Yalom, sobre os fatores terapêuticos e as revisões desta escala que se seguiram, embora não esgotem a ampla gama de possibilidades de estudo e pesquisa na área da terapia de grupo, possibilitaram a abertura de novas direções para os pesquisadores da área. Yalom propôs onze fatores terapêuticos que, segundo seus estudos, poderiam estar presentes nos mais diversos grupos terapêuticos existentes, quais sejam: 1) instilação de esperança; 2) universalidade; 3) oferecimento de informações; 4) altruísmo; 5) desenvolvimento de técnicas de socialização; 6) comportamento imitativo; 7) catarse; 8) reedição corretiva do grupo familiar primário; 9) fatores existenciais; 10) coesão do grupo; e 11) aprendizagem interpessoal. Segundo VINOGRADOV \& YALOM (1992)

"vários tipos de grupos fazem uso de diferentes conjuntos de fatores terapêuticos e, além disto, à medida que um grupo evolui, variados conjuntos de fatores entram em cena. Três forças modificadoras influenciam os mecanismos terapêuticos que operam em qualquer grupo: o tipo de grupo, o estágio da terapia e as diferenças individuais entre os pacientes" (p.35).

Esta proposição gerou um grande número de estudos visando compreender o processo grupal por meio da presença dos fatores terapêuticos, considerando-se as variáveis que podem influenciar este mesmo processo. 
BLOCH, REIBSTEIN, CROUCH, HOLROYD \& THEMEN (1979) revisaram a taxonomia proposta por Yalom, usando uma estrutura mais atéorica e o "questionário do incidente crítico" como forma de operacionalizar os fatores, e não encontraram evidências para os fatores existenciais e para a reedição corretiva do grupo familiar. Estes autores concluíram pela existência de dez fatores terapêuticos no grupo, quais sejam: 1) catarse, 2) altruísmo, 3) universalidade, 4) instilação de esperança, 5) aprendizagem vicária, 6) orientação, 7) aprendizagem através da ação interpessoal, 8) aceitação/coesão grupal, 9) auto-revelação e 10) auto-entendimento. De acordo com seus estudos, esses fatores envolvem três dimensões: cognitiva, comportamental e afetiva.

Estudos foram realizados ao longo dos anos seguintes, verificando como os fatores terapêuticos, divididos nas dimensões descritas por BLOCH et al. (1979), ocorriam ao longo do desenvolvimento do grupo [Butler, 1981; Kivlighan \& Mullison, 1988 e Mackenzie, 1987, apud KIVLIGHAN \& GOLDFINE (1991)].

Estudos como os de KIVLIGHAN \& GOLDFINE (1991); AGAPETUS (1994); STONE, LEWIS \& BECK (1994); SCHAUGHNESSY \& KIVLIGHAN (1995); MISHNA (1996) são exemplos de pesquisas que utilizaram a noção de fatores terapêuticos como forma de situar algumas variáveis em suas relações com dimensões do processo grupal.

Problemas metodológicos, no entanto, limitam a generalização dos resultados obtidos, sobretudo em razão do problema que é equacionar os estágios de desenvolvimento de grupo em função do tempo. Por isto, tem sido difícil testar a hipótese proposta por Yalom, dada a existência de poucas medidas empíricas para operacionalizar os estágios do grupo (VINOGRADOV \& YALOM, 1992).

As variáveis relativas às diferenças individuais relacionadas aos fatores terapêuticos têm recebido menos atenção de pesquisa. VINOGRADOV \& YALOM (1992) relataram que idade, sexo, e nível de instrução não apareceram como importantes pontos de influência na determinação dos fatores terapêuticos presentes num determinado grupo. KIVLIGHAN \& GOLDFINE (1991) apontaram, dentre as variáveis de diferenças individuais que foram consideradas em seu estudo e também foram referidas por outros pesquisadores, as seguintes: a) nível de funcionamento, b) diagnóstico clínico e c) problemas típicos. Porém, os autores chamam atenção para o 
fato de que estas variáveis têm sido freqüentemente confundidas com tipo de grupo, o que torna a generalização dos resultados algo bastante difícil.

As pesquisas apontam também evidências que têm dado um crescente suporte à noção de que o estilo interpessoal do paciente (comportamentos / atitudes) afeta o processo terapêutico e suas conseqüências. KIVLIGHAN \& GOLDFINE (1991) concluíram que participantes do grupo com diferentes estilos interpessoais valorizam diferentes aspectos terapêuticos da experiência de grupo.

Assim, tendo em vista os dados mencionados sobre o desenvolvimento de pesquisas a respeito dos fatores terapêuticos que operam em um grupo, fica evidente a complexidade de um método de investigação que contemple o maior número possível de variáveis para uma visão mais ampla dos processos grupais.

Por outro lado, a revisão de BLOCH et al. (1979) sobre os fatores terapêuticos constitui-se, em nosso ponto de vista, e com base nas pesquisas recentes (KIVLIGHAN \& GOLDFINE, 1991; STONE et al. 1994; SHAUGHNESSY \& KIVLIGHAN, 1995; MISHNA, 1996) um recurso relevante, até mesmo por apresentar um sistema descritivo que favorece a operacionalização da pesquisa nesse campo.

Em relação às bases teóricas e empíricas do conceito de fator terapêutico, a literatura nos situa quanto ao real desenvolvimento da pesquisa nesta área.

CROUCH, BLOCH \& WANLASS (1994) referem que a noção de que fatores terapêuticos operam no tratamento psicoterápico existe com base na assunção de que se pode produzir uma classificação dos elementos benéficos da psicoterapia. Neste artigo, estes autores propõem-se a abordar a questão da utilidade do conceito de fator terapêutico na descrição do funcionamento da terapia de grupo, e para tanto, por meio de uma revisão bibliográfica, discutem a base teórica e empírica destes fatores. Em termos conceituais, os autores apontam para a falta de um consenso sobre a definição do que seja fator terapêutico, sendo que ao longo dos anos, vários estudos realizados sugeriram a existência de diferentes fatores terapêuticos operando nos grupos.

Um marco conceitual na teorização sobre fatores terapêuticos foi o estudo de Corsini \& Rosemberg (apud CROUCH et al. (1994), que concluíram pela existência de dez fatores, definidos a partir de uma revisão de trezentos artigos. Outros estudos 
subsequientes evidenciaram também a maioria destes fatores atuando nos grupos (como as classificações propostas por YALOM, 1970, e por BLOCH et al.,1979).

YALOM (1970) propôs onze fatores terapêuticos, enfatizando uma perspectiva interpessoal na análise do fenômeno grupal. Em seu estudo, apontou que

"a maneira como um indivíduo é ajudado em uma terapia de grupo é resultado de um interjogo de muitos fatores: suas necessidades interpessoais, suas forças e fraquezas, seus recursos extra-grupais, e a composição e cultura de seu grupo de terapia específico" (p.81).

Essa concepção sugere implicitamente que os resultados terapêuticos da participação em grupo não decorrem apenas do que ocorre no grupo, assim chamando a atenção para a complexidade de um estudo que contemple todas as dimensões que estão envolvidas na melhora das condições dos pacientes, dado que fatores terapêuticos ocorreriam em diferentes áreas da vida do sujeito.

Em relação à definição de fator terapêutico apresentada por BLOCH et al. (1979), a partir da sua revisão sobre a classificação dos fatores terapêuticos proposta anteriormente por Yalom, esta se apresenta como "um elemento da terapia de grupo que contribui para melhorar a condição do um paciente e pode ser decorrente das ações do terapeuta do grupo, dos outros membros do grupo e do próprio paciente" (p.271).

CROUCH et al. (1994) realizaram uma revisão sobre cada um destes fatores isoladamente, investigando seus fundamentos teóricos e empíricos, e concluíram que, de fato, há pouca pesquisa sobre o tema, o que sugere a carência de um suporte empírico ao conceito de fator terapêutico. A maioria dos fatores necessita de uma maior investigação experimental, porém estão baseados em consistentes evidências clínicas que enfatizam a importância destes fatores e seu aparecimento nos diferentes grupos.

Ainda em relação à pesquisa neste campo, YALOM (1970) aponta que existiriam três principais métodos para se investigar quais fatores terapêuticos operariam em um determinado grupo: o ponto de vista dos participantes; o ponto de vista dos terapeutas; e estudos sistemáticos correlacionando variáveis da terapia com os resultados obtidos pelo paciente no tratamento. Contudo, apesar de apontar estas três formas como possíveis meios de investigação sobre os fatores, refere 
dificuldades metodológicas inerentes a qualquer uma delas, como por exemplo, a possibilidade de que a percepção dos fatores pelos terapeutas seja permeada pelo viés de sua formação teórica, valorizando, assim, mais alguns fatores do que outros; os participantes poderiam dar respostas por demais subjetivas, ignorando fatores que poderiam ter natureza mais inconsciente; e a realização de estudos sistemáticos remete a considerações sobre a dificuldade de selecionar e mensurar variáveis de terapia, bem como pensar em termos de resultado.

CROUCH et al. (1994) reconhecem, ainda, que "poucos estudos têm examinado a relação entre fatores terapêuticos e resultados, uma questão considerada importante para os pesquisadores e para os clínicos", e apontam também para o fato de que "as relações entre os fatores terapêuticos e o desenvolvimento do grupo necessita de maior investigação" (p.305). Assim, concluem que há uma série de limitações no conceito de fator terapêutico, apontando entre elas: 1) desequilíbrio em seus conteúdos; 2) a sobreposição dos fatores, o que torna difícil uma classificação de um evento em um único fator terapêutico, sobretudo quando se emprega a metodologia do incidente crítico; e 3) a possibilidade de influência das diferenças de perspectiva na classificação dos fatores, segundo a percepção ou dos pacientes ou dos terapeutas. Coerentemente, os autores sugerem uma série de implicações para pesquisa futura, onde apontam desde a necessidade de maior clareza e definição dos conceitos, à necessidade e possibilidade de replicação e generalização dos resultados e o desenvolvimento de medidas e pesquisas de validade e confiança em relação aos fatores terapêuticos.

Percebe-se, portanto, uma certa convergência entre as críticas feitas por estes autores à classificação dos fatores terapêuticos e ao uso deste referencial como aparato metodológico na avaliação dos resultados do processo do grupo. Por outro lado, a literatura também aponta para a real dificuldade de se estudar o fenômeno grupal, em razão de sua complexidade e da quase impossibilidade de um controle de todas as variáveis que interferem neste processo.

CROUCH et al. (1994) reconhecem esta dificuldade no estudo dos fatores terapêuticos, e apontam como a estratégia mais comum neste tipo de estudo a colaboração dos participantes, seja por meio da aplicação da escala dos fatores 
terapêuticos de YALOM (1970), e avaliada pelo método Q-sort, seja pelo uso do Questionário do Incidente Crítico. Estes autores referem que

“...a estrutura de classificação dos fatores tem propiciado a investigação de algumas questões, tais como: a efetividade dos fatores terapêuticos na produção de mudança clínica; a avaliação comparativa dos membros do grupo; a relação entre os fatores e as diferenças grupais; e a relação entre os fatores e diferenças individuais" (p.297).

Assim, apesar das limitações presentes no emprego deste referencial conceitual, muito já pôde ser desenvolvido na área, e estão abertas várias perspectivas de investigação do fenômeno grupal. É unânime na literatura sobre o tema apontamentos que versam sobre a dificuldade de se encontrar uma abordagem metodológica que consiga apreender o processo do grupo em sua amplitude. Concordamos com CROUCH et al. (1994) que

“... apesar das limitações, a qualidade da pesquisa dos fatores terapêuticos é comparável ao trabalho existente em outras áreas da psicoterapia e parece estar alcançando maior base empírica para a prática da psicoterapia de grupo" (p.307).

Quanto à forma como vem sendo produzido o conhecimento científico na área, de acordo com Kaul \& Bednar apud PIPER (1996) muitos estudos realizados limitaram-se a tentar demonstrar a eficácia dos grupos estudados, sendo quase ausentes os estudos que se voltaram para a compreensão de como e porquê a terapia de grupo funciona. Justificaram a ausência de estudos deste tipo em razão da “complexidade conceitual”, e sugeriram que "do que o campo precisa é saber como o paciente, o terapeuta, o relacionamento e as características grupais medeiam a mudança" (p.562).

Este autor situa a classificação em fatores terapêuticos como uma das modalidades de estudo do fenômeno grupal que teria como objetivo apreender uma dimensão do processo terapêutico, apesar das críticas feitas a tal classificação. Segundo aponta, "tais fatores são vistos como mediadores da mudança terapêutica" (PIPER, 1996, p.563). Assim, concluem que este referencial teórico pode ser útil em estudos que almejam a compreensão do processo grupal. 
Outro aspecto a ser considerado é que a maioria dos autores consultados, ao concluírem pela importância de novos estudos que busquem maior validade empírica do conceito e possibilidade de generalização e replicação dos dados (CROUCH et al.,1994; PIPER, 1996), assumem um modelo de pesquisa baseado em uma perspectiva positivista de abordagem do fenômeno grupal. Desta forma, parecem valorizar pesquisas que estabeleçam relações causais entre fatores terapêuticos e mudança, centrando a investigação em uma perspectiva de análise de resultados. Nesta perspectiva de análise, tem-se uma visão linear da intervenção, em que se busca uma avaliação comparativa entre "antes" e "depois", e que recorta dois tempos isolados do processo do grupo, reduzindo a amplitude deste fenômeno. Reside ainda nesta conceituação, uma visão de que a "mudança" ou "melhora" do paciente deve-se unicamente a aspectos internos ao grupo.

É bastante complexa esta discussão. YALOM (1970) já apontava a influência de variáveis internas e externas ao grupo no aparecimento dos fatores terapêuticos. Além disso, subjacente a esta questão, encontra-se uma discussão sobre os conceitos de "mudança" ou do que é "terapêutico", o que tem rendido discussões inconclusivas na literatura sobre o assunto.

De qualquer modo, pensamos não poder restringir o que é terapêutico unicamente ao que ocorre com o paciente no contexto intra-grupo, pois não temos controle sobre a rede de relações externas ao grupo. Fora do grupo, o sujeito está exposto a variadas condições, e não poderíamos reduzir unicamente ao grupo, a possibilidade de produzir e transformar os significados que determinam a necessidade do paciente buscar uma ajuda psicoterápica ou de melhorar sua condição atual. Daí a dificuldade apontada na literatura de se fazer pesquisa sobre o processo grupal em particular, e em psicoterapia em geral, tendo em vista o privilégio dado a estudos nos moldes experimentais, que visam controle de variáveis e atribuição de causalidade.

Entendemos como uma possibilidade rica de abordagem do fenômeno grupal o entendimento dos sentidos e significados que se produzem no grupo a partir da visão dos pacientes sobre o que nele ocorreu. Neste sentido, o esquema conceitual dos fatores terapêuticos pode ter a função de descrever esses significados vividos pelo paciente como importantes a partir de sua participação no grupo. 
Concordamos com BLOCH et al. (1979) que definem fator terapêutico como "um elemento da terapia que contribui para a melhora de uma condição do paciente e pode ser decorrente das ações do terapeuta do grupo, dos outros membros do grupo e do próprio paciente" (p.271). Admitimos que a importância que o paciente atribui a algo tem a ver com o contexto em que esta significação se produziu, ou seja, aquilo que o paciente refere como importante, após ter participado de um grupo psicoterapêutico, tem íntima relação com o contexto de tratamento em que esta significação se produziu. Assim, poderíamos, por exemplo, extrair da cada fator terapêutico estes conceitos "implícitos". Por exemplo, definir altruísmo como "o cliente sente-se melhor em relação a si mesmo, ajudando outros membros" (Bloch et al. apud KIVLIGHAN \& GOLDFINE (1991), pode sugerir a idéia de que ajudar outros membros do grupo faz o paciente sentir-se melhor em relação a si mesmo, o que exerce efeitos terapêuticos para o indivíduo, segundo evidências clínicas. Sob esta perspectiva, a classificação em fatores terapêuticos das respostas dos pacientes, pode alcançar alguns significados que possibilitam uma interpretação desses sentidos, assim permitindo uma leitura significativa deste fenômeno.

Concluímos, então, que apesar das dificuldades metodológicas na pesquisa em psicoterapia de grupo, a necessidade de estudos sobre esta prática, faz-se urgente em nossa realidade, sobretudo quando se atenta para a quase inexistência de literatura nacional sobre o assunto.

Além disso, conforme já apontamos, outro aspecto mencionado na literatura sobre o tema é a grande imprecisão conceitual nas definições dos mais variados grupos existentes (DIES, 1992; SCHOPLER \& GALINSKY, 1993; ISHARA, 1996). Este aspecto torna fundamental a compreensão da natureza dos grupos estudados, para além de suas denominações, visando um entendimento sobre as possibilidades e limites terapêuticos oferecidos pelas diversas modalidades de tratamento em grupo.

Portanto, considerando nosso contexto e tendo em vista nossa realidade social, este fenômeno que na prática já adquire grande importância nos atendimentos em Saúde Mental reclama maior atenção dos pesquisadores, e para ele voltamos nossa atenção. 


\section{2- OBJETIVOS}

Visando contribuir com o conhecimento na área de psicoterapia de grupo, objetivou-se neste estudo compreender os limites e possibilidades de um grupo de apoio com pacientes psiquiátricos ambulatoriais, em sua condição natural, através da:

a) descrição do manejo terapêutico desse grupo com base nas intervenções do seu coordenador; e

b) identificação dos fatores terapêuticos que operam nesse grupo e a incidência destes ao longo das sessões, segundo a perspectiva dos participantes. 


\section{3 - A PESQUISA DE CAMPO}

\section{1- O Delineamento metodológico do estudo}

Admitindo que a própria natureza do processo psicoterápico, marcado por enorme dinamicidade e pluralidade de sentidos, exige uma concepção de conhecimento que signifique este fenômeno em dimensões que extrapolem uma leitura linear do processo grupal, é que situamos nosso estudo em uma perspectiva naturalística, não experimental.

SELLTIZ, WRIGHTSMAN \& COOK (1987) apontam que
"uma preocupação com uma situação natural envolve o registro do comportamento em um contexto que não é estabelecido para o propósito único ou principal de se fazer pesquisa" (p.97). Isto significa estudar o fenômeno "tal como ele ocorre e nas circunstâncias que espontaneamente o geram” (p.96).

Nesta perspectiva, o pesquisador busca interferir o mínimo possível na realidade estudada, a fim de ter acesso aos fenômenos em suas reais condições de produção. Focalizar o processo é estar atento ao modo como algo acontece, mais do que para os resultados obtidos (PATTON,1983).

KUDE (1997) refere que "de modo geral e esquemático, problemas que são formulados com como, qual, o quê, por quê, prestam-se sobremaneira à investigação através do método qualitativo" (p.16), enquanto que problemas que são formulados estabelecendo relações, especialmente aqueles que buscam verificar presença / ausência das variáveis estudadas, são muito apropriados ao método quantitativo.

Assim, de acordo com nossos objetivos, consideramos ser adequado o emprego de métodos de investigação qualitativos e quantitativos. Por meio de um método qualitativo pretende-se verificar quais fatores terapêuticos estarão presentes no grupo estudado e, quantitativamente, verificar qual a incidência destes fatores ao longo das sessões do grupo. Do mesmo modo, pretende-se descrever as modalidades de intervenção do coordenador no grupo e pela sua incidência caracterizar o manejo do grupo.

PATTON (1990) observa que o desenho da pesquisa qualitativa é flexível, de modo que o pesquisador não deve especificar hipóteses testáveis ou variáveis 
operacionais próprias ao modo da pesquisa experimental, mas sim estar atento às mudanças que ocorrem durante o processo investigativo. Ao assim situarmos nosso estudo, partilhamos da definição de MINAYO (1996) de que se entende por pesquisa

“...a atividade básica das Ciências na sua indagação e descoberta da realidade. É uma atitude e uma prática teórica de constante busca, que define um processo intrinsecamente inacabado e permanente. É uma atividade de aproximação sucessiva da realidade, que nunca se esgota, fazendo uma combinação particular entre teoria e dados" (p.23).

Esta definição não atribui o caráter de Ciência a uma ou outra forma de produção de conhecimento (e, por conseguinte, a uma ou outra concepção de realidade) e, por isso, nos permite optar por um método que melhor se adeqüe ao objeto a ser estudado.

Assim, com base nesta visão de ciência, propomos este delineamento metodológico para a investigação do processo grupal, por considerarmos ser coerente e compatível com a natureza do fenômeno estudado e com nossos objetivos neste estudo.

\section{2- Contexto}

O contexto deste estudo foi um Serviço público de saúde do município de Ribeirão Preto que oferece tratamento ambulatorial em Saúde Mental. Conforme se observa na FIGURA 01, trata-se de um dos ambulatórios da rede de atendimento em saúde mental da DIR-XVIII.

De acordo com as rotinas do referido ambulatório, os pacientes são encaminhados ao Serviço por várias instituições de saúde do município. Depois de triados, são encaminhados, de acordo com as necessidades observadas, aos diferentes serviços de atendimento em Saúde Mental oferecidos por esta instituição. Dentre os atendimentos existentes, encontra-se a modalidade de atendimento em grupos de apoio. Quando encaminhados para esta modalidade de tratamento, os pacientes são entrevistados pelo coordenador para admissão no grupo. Nesta entrevista procede-se uma avaliação sobre a adequação do tipo de tratamento oferecido para este paciente 
específico, bem como uma orientação e esclarecimento de dúvidas acerca do atendimento grupal, além de firmar-se o contrato para a participação no grupo.

Estes grupos são coordenados por um médico psiquiatra com experiência profissional e que há quatro anos realiza essa modalidade de atendimento, dentre outras, neste serviço. Em geral, são inicialmente constituídos por 13 (treze) participantes, que são pacientes psiquiátricos ambulatoriais e que freqüentemente fazem seguimento medicamentoso realizado por psiquiatras do próprio ambulatório. O grupo reúne-se semanalmente, por um período de uma hora e meia, ao longo de quatro meses e constitui-se como um grupo fechado. Ao término, os pacientes ou obtêm alta ou são re-encaminhados para outro grupo, ou ainda para outras modalidades de atendimento.

Assim, o objeto deste estudo consistiu de um grupo de apoio de curta duração, oferecido nesta instituição a pacientes ambulatoriais, no período de março a julho de 1998.

FIGURA 1- Figura esquemática do sistema de Saúde da DIR-XVIII, conforme apresentada por VILELA, PANTALIÃO, DEL-BEM \& ZUARDI (1999) 


\section{$\underline{\text { 3.3- Consentimento informado }}$}

Este estudo foi realizado considerando-se os aspectos éticos pertinentes a pesquisas envolvendo seres humanos, tendo sido submetido à avaliação pela Comissão de Ética Médica responsável desta instituição.

Assumiu-se desde o início o compromisso de solicitar o Consentimento Informado dos participantes, cujo modelo (ANEXO 1) foi elaborado de acordo com a "Resolução n 196/96 Sobre Pesquisa Envolvendo Seres Humanos" (BRASIL: MINISTÉRIO DA SAÚDE, CONSELHO NACIONAL DE SAÚDE, 1996).

Este documento consistiu de solicitação aos pacientes para participação no estudo, após serem informados sobre o mesmo e sobre os direitos que lhe eram reservados. Os pacientes foram informados que o grupo era objeto de estudo e que para tanto as sessões seriam gravadas em audio e acompanhadas por um observador silente. Foram informados ainda que a participação voluntária no estudo implicaria em sua colaboração para responder a um questionário relativo a cada sessão do grupo, tendo sido garantindo o sigilo e a utilização do material estritamente para fins de pesquisa. Além disto, este consentimento garantia ao paciente o direito de interromper sua colaboração na pesquisa a qualquer momento, caso julgasse necessário, sem que isto implicasse em prejuízos em seu atendimento no serviço.

Este consentimento foi solicitado individualmente, por ocasião da entrevista de admissão realizada pelo psiquiatra responsável pelo atendimento do grupo, que constituiu o grupo apenas com os pacientes que concordaram em participar do estudo. 


\section{4- Materiais e procedimentos de coleta e análise dos dados}

\subsection{1- Fontes Complementares}

Consideramos como fontes adicionais as informações obtidas a partir das consultas aos prontuários dos pacientes; do formulário de avaliação do nível de ajustamento psicossocial dos mesmos; e das notas de diário de campo. Estes dados possibilitaram uma melhor caracterização e descrição dos pacientes que participaram do grupo de apoio.

A) Consultas aos prontuários

Realizou-se consultas regulares aos prontuários do serviço com o objetivo de resgatar informações sobre as consultas individuais dos pacientes na psiquiatria (PQU), sistematizando dados sobre história clínica (evolução da moléstia atual, diagnóstico, prognóstico), condutas médicas (plano terapêutico), principais queixas referidas, além de dados de identificação (idade, sexo, escolaridade, grau de instrução, profissão, etc).

Após um intervalo de quatro meses do término do grupo, realizou-se nova consulta a estes prontuários, assim verificando as condições atuais dos pacientes e as condutas tomadas junto a cada um deles após o grupo.

\section{B) Formulário de Avaliação do Nível de Ajustamento Psicossocial}

Como forma de sistematização e complementação dos dados dos prontuários, foi preenchido, pelo médico psiquiatra coordenador do grupo, um "Formulário de Avaliação do Nível de Ajustamento Psicossocial do Paciente", em dois momentos distintos - início e término de sua participação no grupo. O modelo do formulário utilizado encontra-se em anexo (ANEXO 2).

Esse formulário foi elaborado tendo como referência categorias presentes na Escala do Diagnóstico Adaptativo Operacionalizada (EDAO) proposta por Simon 1989, 1995) ao abordar o tema da prevenção em Psicologia.

De acordo com SIMON (s/d) pode-se definir adaptação como "um conjunto de respostas de um organismo vivo a situações que a cada momento o modificam, permitindo a manutenção de sua organização (por mínima que seja) compatível com 
a vida" (p.14). Segundo este autor, para que se torne um conceito de adaptação operativo, é necessário graduá-lo, e por isto propõe a avaliação escalonada de quatro fatores de funcionamento: afetivo-relacional, produtividade, sócio-cultural e orgânico.

COSTA-ROSA (s/d) refere que esta concepção de adaptação proposta por Simon, "vai além do modelo biológico, procurando incluir a dimensão evolutiva da relação do indivíduo consigo próprio e com o meio" (p.13), incluindo os conceitos de crise e de situações problemas. Assim, a EDAO permite avaliar e prevenir situações de crise ou de maiores dificuldades em alguns setores da vida do sujeito, pois esta escala não visa discriminar entre as grandes categorias nosológicas utilizadas em psiquiatria, já que em muitos casos as pessoas sujeitas a esta avaliação, embora vivenciando dificuldades em alguns setores de sua vida, encontram-se classificadas dentro dos padrões de normalidade nas categorias diagnósticas mais gerais, o que dificultaria a discriminação de suas necessidades de atendimento psicológico.

Frente a tais considerações e tendo em vista nossos propósitos, em nossa avaliação incluímos alguns aspectos considerados descritivos do modo de funcionamento psicossocial e da adaptação do paciente, escalonados em três níveis discriminativos. Assim, as seguintes dimensões do nível de ajustamento psicossocial do paciente foram avaliadas: 1) aspecto afetivo-relacional; 2) aspecto produtivo; 3) aspecto sócio-cultural; 4) capacidade adaptativa; e 5) avaliação global.

\section{C) Diário de campo}

Também notas de diário de campo foram efetuadas pela pesquisadora durante sua participação no grupo como observadora silente e no período de coleta de dados, registrando elementos do contexto e das interações entre os participantes do grupo.

Notas de campo são registros que contêm anotações detalhadas sobre aspectos vários que puderam ser observados no contato com o objeto de estudo. De acordo com SELLTIZ et al. (1987) "pode incluir infinitos detalhes acerca do momento e do local de uma entrevista ou observação" (p.77). Ainda segundo estes autores, nem todos os detalhes são relevantes para a análise, mas o que de fato será importante o pesquisador só saberá no momento da análise. 
Assim, foi realizado um registro de campo visando favorecer uma reflexão mais abrangente sobre os dados obtidos por meio das outras fontes utilizadas neste estudo.

Os procedimentos acima descritos (consultas aos prontuários; avaliação do nível de ajustamento psicossocial dos pacientes; e diário de campo) permitiram uma caracterização geral dos participantes do grupo.

\subsection{2- Observação e registro do grupo}

O registro do grupo foi realizado através da gravação em audio de todas as 16 (dezesseis) sessões, bem como através dos registros de observação das mesmas, redigidos pela pesquisadora durante os encontros. As fitas foram transcritas na íntegra pela pesquisadora acrescidas de informações sobre comportamentos e estados afetivos percebidos durante a observação do grupo.

Com base nesse registro audio-gravado procedeu-se uma descrição das sessões do grupo, a partir da definição de alguns eixos de análise: os participantes presentes em cada sessão do grupo; os assuntos referidos; os temas discutidos; o padrão predominante de interação entre os membros; a tonalidade afetiva presente no grupo; a postura do coordenador; e a impressão da observadora a partir de suas anotações durante o grupo e também nas notas de diário de campo. Esta síntese das sessões foi concluída a partir de uma leitura exaustiva das mesmas, que permitiu a percepção dos eixos centrais de análise e das particularidades de cada uma das sessões.

Também a partir do registro destas sessões, realizou-se a análise do manejo do grupo, com base em procedimentos de análise de conteúdo das intervenções do coordenador ao longo dos encontros.

BARDIN (1988) refere a análise de conteúdo como um

"conjunto de técnicas de análise de comunicação visando obter, por procedimentos sistemáticos e objetivos de descrição do conteúdo das mensagens, indicadores (quantitativos ou não) que permitam a inferência de conhecimentos relativos às condições de produção / recepção (variáveis inferidas) dessas mensagens" (p.42). 
Assim, objetiva-se, por meio desse procedimento de análise, apreender sentidos que apresentem alguns indicadores maiores sobre o que pode ser extraído dos dados, tendo em vista o apontamento de que "o interesse não reside na descrição dos conteúdos, mas sim no que estes nos poderão ensinar após serem tratados, relativamente a 'outras coisas"” (BARDIN, 1988, p.38).

Em nosso estudo, essa análise teve por finalidade permitir uma classificação das diferentes formas de intervenção do coordenador a partir de seus elementos comuns, assim possibilitando um entendimento sobre a natureza do grupo e da forma como foi conduzido em seu processo. Tomamos como referência inicial algumas definições presentes na literatura sobre intervenções consideradas terapêuticas numa situação clínica. Porém, estas pareceram insuficientes para traduzir a especificidade de nossos dados, e assim optamos por formular um sistema de categorias constituídas a partir do próprio processo de análise do material. Esse sistema foi elaborado pela autora em conjunto com uma outra pesquisadora, a partir da leitura exaustiva dos dados, buscando significar as intervenções do coordenador no processo interativo do grupo. Após definidas as categorias, todas as intervenções do coordenador foram tomadas em seu contexto de interação e classificadas pela autora.

Para a análise da fidedignidade dessa classificação, todas as intervenções foram enumeradas em seqüência, de modo que a primeira intervenção em cada sessão recebia a numeração consecutiva da última da sessão anterior. Selecionou-se dez por cento $(10 \%)$ de todas as intervenções do coordenador ao longo das sessões do grupo (a primeira de cada dez intervenções), de modo a constituir uma amostra casual simples, prevendo a aleatoriedade das intervenções selecionadas para análise, e permitindo, assim, que vários momentos do grupo fossem verificados (ANEXO 3). A classificação independente dessas intervenções no sistema de categorias criado foi realizada por um juiz, e a partir disto, procedeu-se o cálculo de acordo entre a classificação da autora e a do juiz, a partir da fórmula (ISHARA, 1996):

$$
\% \text { acordo }=\frac{\text { total de avaliações }- \text { desacordos x } 100}{\text { total de avaliações }}
$$

O índice de acordo obtido através deste procedimento foi de $88 \%$. 


\subsection{3- Questionário do Incidente Crítico}

Para se ter acesso à percepção dos participantes do grupo foi utilizado o utilizado o QUESTIONÁRIO DO INCIDENTE CRÍTICO (Critical Incidents Questionaire - CIQ), conforme descrito por FLANAGAN (1954).

Segundo esse autor, "a técnica do incidente crítico é essencialmente um procedimento para obter fatos importantes acerca de comportamentos numa situação definida" (p.335) e que tem a vantagem de propiciar um registro específico que favorece uma avaliação adequada destes comportamentos. Basicamente, considera-se como críticos relatos que contêm uma descrição da situação na qual o incidente ocorreu, uma descrição do comportamento do respondente e também as conseqüências deste mesmo comportamento.

O Questionário do Incidente Crítico vem sendo amplamente empregado em pesquisas relacionadas à investigação dos fatores terapêuticos (KIVLIGHAN \& GOLDFINE, 1991; SHAUGHNESSY \& KIVLIGHAN, 1995) e para tal tem sido utilizado com as seguintes questões: Dos eventos que ocorreram na última sessão do grupo, qual deles você sentiu ser o mais importante para você pessoalmente? Descreva o evento: o quê realmente aconteceu, quais os membros do grupo envolvidos, e qual foi a sua própria reação? Por que isto foi importante para você?

Nesse estudo utilizamos o mesmo questionário, porém com algumas alterações no modo com as questões foram redigidas a fim de tornar a linguagem mais acessível à clientela atendida no grupo. $\mathrm{O}$ modelo do questionário utilizado encontra-se em anexo (ANEXO 4).

Os pacientes do grupo já haviam sido informados sobre a existência do questionário, tendo concordado com o preenchimento do mesmo no momento em que concederam aos pesquisadores o Consentimento Informado para a participação no estudo. Ainda assim, na primeira sessão do grupo, o coordenador e a pesquisadora forneceram explicações e orientações verbais sobre o significado das questões, esclarecendo as eventuais dúvidas, o que novamente foi retomado na segunda sessão do grupo. Em casos de pacientes que apresentaram dificuldades para responder por problemas de escrita, a pesquisadora redigia suas respostas conforme ditadas pelos mesmos. Assim, ao término de cada sessão do grupo, o coordenador e a pesquisadora 
solicitavam aos pacientes que respondessem ao QIC, o que levava entre dez e trinta minutos.

Também para a análise do QIC foi utilizado o procedimento de análise categorial de conteúdo, conforme proposto por BARDIN (1988), a partir de um sistema à priori de categorias, a saber, o sistema classificatório proposto por BLOCH et al. (1979) dos fatores terapêuticos. Então, para a classificação das respostas dos pacientes ao QIC utilizamos as definições dos fatores terapêuticos apresentadas por estes autores como norteadoras de nossa análise, e que se encontram no Manual de Classificação dos Fatores Terapêuticos, que apresentamos no ANEXO 5. Este Manual contêm uma descrição pormenorizada das definições de cada fator, facilitando a categorização do material.

Em relação à análise deste material, ao invés de proceder a classificação independente dos fatores e efetuar cálculo de acordo entre juízes, conforme realizamos na análise do manejo do grupo, optou-se por classificar todo o material por dois avaliadores (a autora e uma outra pesquisadora) buscando-se consenso nos julgamentos. Em casos de dificuldades de classificação nas categorias pré-existentes, criamos conjuntamente novas categorias ou procedemos algumas alterações quando acreditamos não haver grandes diferenças de sentido, de forma a que o material pudesse ser melhor descrito em sua especificidade. 


\section{4- O GRUPO ESTUDADO}

\section{1- A composição do grupo}

O grupo foi constituído pelo médico responsável por este atendimento, a partir de entrevista de triagem, sendo selecionados para a participação neste grupo específico apenas os pacientes que não se opuseram em colaborar neste trabalho de pesquisa, assinando o Consentimento Informado. Os pacientes que tiveram indicação para atendimento em grupo, mas que se opuseram à participação na pesquisa, integraram um outro grupo, realizado pelo mesmo médico, e que não foi objeto de investigação.

Após a triagem realizada pelo coordenador e a solicitação do consentimento informado, o grupo foi constituído. Participaram inicialmente onze pacientes, de idade, sexo e nível de escolaridade variáveis, bem como diagnósticos distintos, e encaminhados para tratamento na psiquiatria por diferentes serviços de saúde do município de Ribeirão Preto. O acompanhamento destes pacientes na psiquiatria deste ambulatório era feito ou pelo coordenador do grupo ou por outros psiquiatras dessa instituição. Houve a desistência de dois deles até a segunda sessão, e a entrada de um novo membro na quarta sessão do grupo. Consideramos, assim, para efeito de análise dos dados, o grupo como composto por dez pacientes.

O grupo teve 16 sessões semanais (quatro meses) de cerca de uma hora e meia de duração (sessões semanais).

\section{2- Caracterização dos pacientes}

Apresentamos no quadro seguinte (QUADRO 1), dados de identificação dos pacientes integrantes do grupo de apoio, a saber: sexo, idade, estado civil, grau de instrução e profissão. Os nomes dos pacientes aqui apresentados são fictícios, a fim de resguardar suas identidades. Participaram ao longo do grupo dez pacientes, sendo oito mulheres e dois homens, com idades oscilando na faixa de 29 a 65 anos. A maioria apresenta baixo grau de instrução ( $1^{\circ}$ grau incompleto), e trabalha predominantemente em serviços domésticos (seja na própria residência, seja em 
atividades remuneradas ${ }^{2}$, mas com esta mesma função). Quando trabalhando em outras atividades, exercem funções autônomas (no caso dos dois homens do grupo e de duas mulheres que trabalhavam com vendas). Observa-se, ainda, que a maioria dos pacientes é casada, havendo apenas uma paciente solteira e outra divorciada.

QUADRO 1- Caracterização dos pacientes integrantes do grupo $(\mathrm{N}=10)$, incluindo sexo, idade, estado civil, grau de instrução e profisssão, segundo os registros de prontuário do serviço.

\begin{tabular}{|c|c|c|c|c|c|}
\hline Nome fictício & Sexo & Idade & Estado Civil & Instrução & Profissão \\
\hline ROBERTA & $\mathrm{F}$ & 29 & Casada & $1^{\circ}$ grau incompleto & Dona de casa \\
\hline JOÃO & $\mathrm{M}$ & 41 & Casado & $1^{\circ}$ grau incompleto & Empresário \\
\hline ANA MARIA & $\mathrm{F}$ & 47 & Casada & $2^{\circ}$ grau completo & Vendedora \\
\hline MARTA & $\mathrm{F}$ & 39 & Solteira & $1^{\circ}$ grau completo & Desempregada \\
\hline MARLI & $\mathrm{F}$ & 59 & Casada & $1^{\circ}$ grau incompleto & Dona de casa \\
\hline IRENE & $\mathrm{F}$ & 65 & Casada & $1^{\circ}$ grau incompleto & Dona de casa \\
\hline ESTELA & $\mathrm{F}$ & 42 & Divorciada & $1^{\circ}$ grau incompleto & Dona de Casa \\
\hline WALTER & $\mathrm{M}$ & 48 & Casado & $1^{\circ}$ grau incompleto & Autônomo \\
\hline ROSILENE & $\mathrm{F}$ & 38 & Casada & $1^{\circ}$ grau incompleto & Vendedora \\
\hline MARÍLIA & $\mathrm{F}$ & 44 & Casada & $1^{\circ}$ grau incompleto & Doméstica \\
\hline
\end{tabular}

No QUADRO 2, apresentamos os resultados obtidos a partir da consulta aos prontuários dos pacientes do grupo, em relação à história psiquiátrica anterior ao encaminhamento ao serviço. Neste quadro, apresentamos dados acerca dos tipos de tratamento recebidos pelos pacientes antes do atendimento em questão, incluindo tratamentos ambulatoriais, uso de medicação anterior e história de internação ou semi-internação psiquiátrica. A apresentação pormenorizada destes dados encontrase em anexo, permitindo uma visão da história anterior ao ingresso no serviço de cada paciente individualmente (ANEXO 6). Tendo a análise se baseado em anotações de prontuário, em alguns casos as informações não puderam ser obtidas por não constarem nos registros realizados pelos profissionais.

\footnotetext{
${ }^{2}$ não consta dos prontuários destas pacientes informações sobre trabalhos remunerados; porém, relatos de suas experiências em grupo revelam atividades remuneradas, como lavadeira, faxineira ou babá.
} 
QUADRO 2- Distribuição dos pacientes integrantes do grupo em relação aos tipos de tratamentos psiquiátricos anteriores a seus atendimentos no serviço.

\begin{tabular}{|llc|}
\hline Tipo & categorias & $\begin{array}{c}\text { Freq. } \\
\mathbf{( N = 1 0}\end{array}$ \\
\hline Tratamento ambulatorial & sim & 06 \\
& não & 02 \\
& Sem informação & 02 \\
\hline Uso de medicação & sim & 09 \\
& não & - \\
& Sem informação & 01 \\
\hline Semi-internação & sim & 01 \\
& não & 09 \\
& Sem informação & - \\
\hline Internação & sim & 01 \\
& não & 09 \\
& Sem informação & - \\
\hline
\end{tabular}

Em relação à história de tratamento ambulatorial anterior, apenas dois pacientes negaram ter passado por algum seguimento psicológico ou psiquiátrico anterior, seis afirmaram tratamentos anteriores e em dois casos os prontuários não continham estas informações. Assim, há predomínio no grupo de pacientes com história de outros tratamentos ambulatoriais em algum período de suas vidas.

A maioria dos pacientes $(\mathrm{N}=09)$ referiu ter feito uso de medicação antes do início de seu tratamento no serviço. Dentre os medicamentos utilizados, houve o predomínio de uso de medicações ansiolíticas e/ou antidepressivas, sendo que apenas um paciente referiu uso de medicação antipsicótica. Deve-se ressaltar que o uso de medicação nem sempre foi feito com acompanhamento médico concomitante.

Em relação à história de internação, apenas um paciente referiu história de internação em hospitais psiquiátricos da região, e um outro referiu ter estado em regime de semi-internação. Os outros oito pacientes negaram história de internação anterior ao seu ingresso no serviço. 
No QUADRO 3, apresentamos alguns dados de prontuário relativos à história psiquiátrica do paciente no serviço, ou seja, desde sua primeira consulta até o momento de encaminhamento para o grupo. Assim, apresentamos o tempo de atendimento na instituição, as queixas inicialmente referidas e as condutas tomadas pelos profissionais junto a estes pacientes. A apresentação pormenorizada destes dados encontra-se no em anexo, permitindo uma visão das principais queixas, dos diagnósticos clínicos e das condutas médicas tomadas no tratamento de cada paciente individualmente anteriores a seu encaminhamento para o grupo (ANEXO 7).

Conforme se observa no QUADRO 3, três pacientes eram atendidos no serviço há cerca de 18 meses e um outro há cerca de um ano, ao serem encaminhados para participação no grupo de apoio. Os outros seis pacientes tinham história relativamente recente de atendimento na instituição, variando de 1 a 6 meses.

Queixas somáticas, ansiedade, depressão, dificuldades de relacionamento e/ou de produção foram as queixas mais freqüentes, sendo que um mesmo paciente muitas vezes apresentava várias destas queixas ao mesmo tempo. Prevalecem sintomas orgânicos, típicos de ansiedade, como agitação, fobias, palpitação, aumento ou diminuição do apetite, ou de depressão, como desinteresse, apatia, desânimo, dificuldades de relacionamento e de exercer atividades rotineiras.

Quanto às condutas tomadas junto a cada participante, a maioria dos pacientes recebeu prescrição de medicação em período anterior a seu atendimento no grupo, sendo que alguns deles também receberam indicação para participação em outros grupos. Apenas dois pacientes haviam recebido seguimento individual, com condutas de orientação / ventilação ou de psicoterapia.

O fato de existir alguns pacientes com prévia experiência de participação em grupo sugere que estes já tivessem um certo conhecimento sobre o modo de organização da situação terapêutica nos grupos, além de um contato prévio com o coordenador, anterior ao seu encaminhamento para o grupo de apoio objeto deste estudo. Devemos apontar também que, embora com seguimento medicamentoso, há referências de muitos pacientes ao fato de interromperem o uso da medicação sem a avaliação médica, conforme os registros de prontuário. 
QUADRO 3- Caracterização dos pacientes integrantes do grupo a partir do início de seu atendimento no serviço antecedendo à indicação e ingresso no grupo.

\begin{tabular}{|llc|}
\hline Tipo & categorias & $\begin{array}{c}\text { Freq. } \\
\text { Tempo no serviço }\end{array}$ \\
& De 1 a 2 meses & 3 \\
& De 4 a 6 meses & 3 \\
Queixas principais * $*$ & Somáticas 12 a 20 meses & 4 \\
& Depressão & 5 \\
& Ansiedade & 6 \\
& Dificuldade de relacionamento & 6 \\
& Dificuldade de produção & 6 \\
Condutas * & Medicação & 5 \\
& Medicação e grupo de apoio & 4 \\
& Medicação e terapia individual & 3 \\
& Medicação, terapia individual e grupo de apoio & 1 \\
& Nenhum dos anteriores & 1 \\
\hline
\end{tabular}

* a somatória não equivale ao $N=10$, em função da possibilidade de inclusão dos pacientes em diferentes categorias (segundo a diversidade das queixas e das condutas sugeridas).

Apresentamos, no QUADRO 4, informações sobre a história clínica psiquiátrica dos pacientes no período anterior ao início do grupo, bem como sobre suas condições clínicas no momento do encaminhamento para o grupo, o que nos permite uma maior visualização dos procedimentos tomados junto a cada paciente neste período e sobre a evolução de seu quadro clínico. Estes dados foram extraídos dos registros de prontuário da instituição, e encontram-se apresentados de modo mais extenso e detalhado nos ANEXOS 7 e 8. 
QUADRO 4- História clínica psiquiátrica dos pacientes anterior ao início de sua participação no grupo, incluindo início do atendimento no serviço, condutas médicas anteriores e no momento do encaminhamento para o grupo, evolução e diagnóstico clínico.

\begin{tabular}{|c|c|c|c|c|c|c|}
\hline \multirow[t]{2}{*}{ Paciente } & \multirow{2}{*}{ nício } & \multirow[t]{2}{*}{ Dificuldades } & \multicolumn{2}{|l|}{ Condutas } & \multirow[t]{2}{*}{ Evolução } & \multirow{2}{*}{$\begin{array}{l}\text { Diag } \\
\text { nóstico }\end{array}$} \\
\hline & & & anteriores & $\begin{array}{c}\text { Momento do } \\
\text { encaminhamento }\end{array}$ & & \\
\hline Roberta & Fev/ 97 & $\begin{array}{l}\text { Queixas somáticas, } \\
\text { ansiedade, dificuldades } \\
\text { de relacionamento. }\end{array}$ & $\begin{array}{l}\text { Medicação } \\
\text { ansiolítica e } \\
\text { grupo de apoio }\end{array}$ & Sem medicação & $\begin{array}{l}\text { Participação em grupo de apoio anterior e } \\
\text { medicação suspensa ao longo dos } \\
\text { atendimentos. } \\
\text { Ansiedade, dificuldades de relaciona- } \\
\text { mento e de produção. }\end{array}$ & $\begin{array}{l}\text { Transtorno de } \\
\text { ansiedade }\end{array}$ \\
\hline João & Out/ 97 & \begin{tabular}{lll|}
$\begin{array}{l}\text { Dificuldades } \\
\text { relacionamento } \\
\text { produção. }\end{array}$ & e & de \\
\end{tabular} & $\begin{array}{l}\text { Terapia } \\
\text { individual }\end{array}$ & $\begin{array}{l}\text { Sem terapia } \\
\text { individual }\end{array}$ & $\begin{array}{l}\text { Menor dificuldade de relacionamento e } \\
\text { de produção; sem outras queixas. }\end{array}$ & $\begin{array}{l}\text { Transtorno } \\
\text { adaptativo }\end{array}$ \\
\hline Ana Maria & Ago/ 96 & $\begin{array}{lr}\text { Depressão, ansiedade, } \\
\text { dificuldades } & \text { de } \\
\text { relacionamento e } & \text { de } \\
\text { produção. } & \end{array}$ & \begin{tabular}{c|} 
Medicação \\
ansiolítica, \\
terapia individual \\
e grupo de apoio
\end{tabular} & $\begin{array}{l}\text { Medicação } \\
\text { ansiolítica }\end{array}$ & $\begin{array}{l}\text { Uso recorrente e descontínuo de } \\
\text { medicação e abandono da terapia } \\
\text { individual; participação em grupo de } \\
\text { apoio anterior } \\
\text { Melhor em relação à depressão e às } \\
\text { dificuldades de produção }\end{array}$ & $\begin{array}{l}\text { Transtorno } \\
\text { depressivo } \\
\text { recorrente, } \\
\text { episódio atual } \\
\text { moderado }\end{array}$ \\
\hline Marta & Set/ 97 & $\begin{array}{l}\text { Depressão, dificuldades } \\
\text { de relacionamento e de } \\
\text { produção. }\end{array}$ & $\begin{array}{l}\text { Medicação } \\
\text { antipsicótica }\end{array}$ & $\begin{array}{l}\text { Medicação } \\
\text { antipsicótica }\end{array}$ & $\begin{array}{l}\text { Aderência ao tratamento medicamentoso } \\
\text { Dificuldades de relacionamento e de } \\
\text { produção; depressão. }\end{array}$ & $\begin{array}{c}\text { Transtorno de } \\
\text { personalidade } \\
\text { borderline }\end{array}$ \\
\hline Marli & Jun/ 96 & 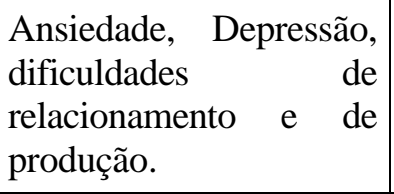 & $\begin{array}{c}\text { Medicação } \\
\text { antidepressiva e } \\
\text { ansiolítica, e } \\
\text { grupos de apoio }\end{array}$ & $\begin{array}{l}\text { Medicação } \\
\text { antidepressiva e } \\
\text { ansiolítica }\end{array}$ & $\begin{array}{l}\text { Uso descontínuo da medicação, } \\
\text { interrompendo o uso por conta própria. } \\
\text { Queixas somáticas, ansiedade }\end{array}$ & Distimia \\
\hline
\end{tabular}


Continuação...

\begin{tabular}{|c|c|c|c|c|c|c|}
\hline \multirow[t]{2}{*}{ Paciente } & \multirow{2}{*}{ nício $^{I}$} & \multirow[t]{2}{*}{ Dificuldades } & \multicolumn{2}{|c|}{ Condutas } & \multirow[t]{2}{*}{ Evolução } & \multirow{2}{*}{$\begin{array}{l}\text { Diag } \\
\text { nóstico }\end{array}$} \\
\hline & & & anteriores & $\begin{array}{c}\text { Momento do } \\
\text { encaminhamento }\end{array}$ & & \\
\hline Irene & Fev/ 98 & $\begin{array}{lr}\text { Queixas } & \text { somáticas, } \\
\text { depressão, } & \text { ansiedade, } \\
\text { dificuldades } & \text { de } \\
\text { produção. } & \\
\end{array}$ & $\begin{array}{c}\text { Medicação } \\
\text { ansiolítica e } \\
\text { antidepressiva }\end{array}$ & $\begin{array}{c}\text { Medicação } \\
\text { ansiolítica e } \\
\text { antidepressiva }\end{array}$ & $\begin{array}{l}\text { Aderência ao tratamento e posterior } \\
\text { redução da medicação } \\
\text { Ver quadro inicial* }\end{array}$ & Distimia \\
\hline Estela & Fev/ 98 & $\begin{array}{l}\text { Queixas somáticas, } \\
\text { depressão. }\end{array}$ & Sem medicação & Sem medicação & Ver quadro inicial* & $\begin{array}{l}\text { Ansiedade } \\
\text { generalizada }\end{array}$ \\
\hline Valter & Out/ 97 & $\begin{array}{l}\text { Queixas somáticas, } \\
\text { ansiedade }\end{array}$ & $\begin{array}{l}\text { Medicação } \\
\text { ansiolítica e } \\
\text { antidepressiva }\end{array}$ & $\begin{array}{c}\text { Medicação } \\
\text { ansiolítica e } \\
\text { antidepressiva }\end{array}$ & $\begin{array}{l}\text { Uso recorrente e descontínuo de } \\
\text { medicação, interrompendo o uso por } \\
\text { iniciativa pessoal } \\
\text { Queixas somáticas, ansiedade }\end{array}$ & $\begin{array}{l}\text { Ansiedade } \\
\text { generalizada }\end{array}$ \\
\hline Rosilene & Jan/ 98 & $\begin{array}{l}\text { Dificuldades de } \\
\text { relacionamento, } \\
\text { queixas somáticas } \\
\text { ansiedade. }\end{array}$ & $\begin{array}{l}\text { Medicação } \\
\text { ansiolítica }\end{array}$ & $\begin{array}{l}\text { Medicação } \\
\text { ansiolítica }\end{array}$ & $\begin{array}{l}\text { Uso abusivo da medicação } \\
\text { Ver quadro inicial* }\end{array}$ & $\begin{array}{c}\text { Transtorno } \\
\text { dissociativo, } \\
\text { anesteisa e } \\
\text { perda } \\
\text { sensoriais } \\
\text { dissociativas }\end{array}$ \\
\hline Marília & Maio/ 96 & Depressão, ansiedade. & $\begin{array}{c}\text { Medicação } \\
\text { ansiolítica e } \\
\text { grupo de apoio }\end{array}$ & $\begin{array}{l}\text { Medicação } \\
\text { ansiolítica }\end{array}$ & $\begin{array}{l}\text { Uso recorrente e descontínuo da } \\
\text { medicação } \\
\text { Melhora na ansiedade, depressão - } \\
\text { assintomática desde que use a medicação. }\end{array}$ & Distimia \\
\hline
\end{tabular}

* o início do atendimento no serviço coincide com o momento de seu encaminhamento para o grupo 
Conforme se observa no QUADRO 4, as principais dificuldades apresentadas pelos pacientes, tanto no momento de ingresso no serviço, como no momento de encaminhamento para o grupo, relacionavam-se a queixas somáticas, depressão, ansiedade, e dificuldades de relacionamento e/ou de produção. As condutas tomadas junto a estes pacientes variaram em função de seus quadros clínicos, sendo predominante a indicação para seguimento medicamentoso e para participação em grupo de apoio. A aderência ao tratamento indicado foi bastante variável, conforme pode-se observar no item "evolução".

Esses dados podem ser percebidos de forma mais global no QUADRO 5, em que apresentamos a condição clínica dos pacientes no momento do encaminhamento para o grupo, segundo avaliação de seu coordenador a partir de entrevista de triagem. Apresentamos nesse quadro as principais queixas referidas, os diagnósticos clínicos destes pacientes e o tipo de medicação prescrita no momento de seu ingresso no grupo de apoio, seguidas de suas respectivas freqüências de aparecimento. A apresentação pormenorizada destes dados encontra-se em anexo, permitindo uma visão destas variáveis por cada paciente individualmente (ANEXO 8).

Conforme se observa no QUADRO 5, as queixas dos pacientes eram relativamente similares no momento do encaminhamento para o grupo. Em termos gerais, observa-se a presença de queixas somáticas, predominantemente relacionadas a quadros de ansiedade e depressão. Problemas de relacionamento familiar e conjugal também foram apontados pelos pacientes, bem como dificuldades relacionadas ao exercício de atividades de trabalho ou atividades domésticas.

Quanto aos diagnósticos clínicos (CID-10), estes se encontravam predominantemente entre os transtornos neuróticos relacionados ao estresse e somatoformes (transtorno de ansiedade, transtorno adaptativo, ansiedade generalizada e transtorno dissociativo), e entre os transtornos de humor (distimia e transtorno depressivo recorrente). Apenas um paciente apresentava diagnóstico de transtorno de personalidade e de comportamentos em adultos (transtorno de personalidade borderline). 
QUADRO 5- Condição clínica dos pacientes no momento de encaminhamento para o grupo, conforme avaliações psiquiátricas registradas nos prontuários.

\begin{tabular}{|c|c|c|}
\hline Tipo & categorias & $\begin{array}{l}\text { Freq. } \\
(\mathrm{N}=\mathbf{1 0})\end{array}$ \\
\hline \multirow[t]{5}{*}{ Queixas principais } & Somáticas & 5 \\
\hline & Depressão & 4 \\
\hline & Ansiedade & 5 \\
\hline & Dificuldade de relacionamento & 4 \\
\hline & Dificuldade de produção & 5 \\
\hline \multirow[t]{3}{*}{$\begin{array}{l}\text { Categorias } \\
\text { Diagnósticas * }\end{array}$} & $\begin{array}{l}\text { Transtornos neuróticos relacionados ao estresse e } \\
\text { somatoformes }\end{array}$ & 5 \\
\hline & Transtorno de humor & 4 \\
\hline & $\begin{array}{l}\text { Transtorno de personalidade e de comportamentos } \\
\text { em adultos }\end{array}$ & 1 \\
\hline \multirow[t]{4}{*}{ Tipo de medicação } & Ansiolítica & 2 \\
\hline & Ansiolítica/ antidepressiva & 4 \\
\hline & Antipsicótica & 1 \\
\hline & Sem indicação & 3 \\
\hline
\end{tabular}

Em relação ao uso de medicamento, a maioria dos pacientes $(\mathrm{N}=07)$ fazia uso de alguma medicação no momento de encaminhamento para o grupo, sendo predominante o uso de medicação ansiolítica e antidepressiva ou de apenas medicação ansiolítica. Apenas um dos pacientes fazia uso de medicação antipsicótica, porém em dosagem ansiolítica. Esse uso predominante de medicação sugere a noção de que estes pacientes pareciam vivenciar, no momento de encaminhamento para o grupo de apoio, uma situação de crise, em uma história de vida marcada pela presença de dificuldades.

Assim, o QUADRO 5 é indicativo da predominância do uso de medicação pelos pacientes do grupo, bem como de uma convergência em relação a seus diagnósticos clínicos, se considerados a partir das categorias diagnósticas mais gerais apresentadas na CID-10. 
No QUADRO 6, apresentamos os resultados obtidos a partir da avaliação psiquiátrica realizada ao início e ao término do grupo. Conforme formulário de avaliação apresentado em anexo (ANEXO 2), este quadro contêm as dimensões avaliadas pelo médico relativas ao ajustamento psicossocial dos pacientes, a saber, aspecto afetivo-relacional, aspecto produtivo, aspecto sócio-cultural, capacidade adaptativa e avaliação global. Esta avaliação foi escalonada em três níveis discriminativos.

QUADRO 6- Ajustamento psicossocial dos pacientes conforme avaliação realizada pelo médico psiquiatra ao início e ao término do grupo.

\begin{tabular}{|c|c|c|c|}
\hline \multirow[t]{2}{*}{ Aspecto } & \multirow[t]{2}{*}{ Índices } & \multicolumn{2}{|c|}{ Freq. $(\mathrm{N}=10)$} \\
\hline & & início & término \\
\hline \multirow[t]{3}{*}{ Afetivo relacional } & Muitas dificuldades & 4 & 3 \\
\hline & Alguma dificuldade & 6 & 5 \\
\hline & Sem dificuldades & 0 & 2 \\
\hline \multirow[t]{3}{*}{ Produtivo } & Muitas dificuldades & 0 & 1 \\
\hline & Alguma dificuldade & 7 & 6 \\
\hline & Sem dificuldades & 3 & 3 \\
\hline \multirow[t]{3}{*}{ Sócio cultural } & Muitas dificuldades & 0 & 0 \\
\hline & Alguma dificuldade & 9 & 6 \\
\hline & Sem dificuldades & 1 & 4 \\
\hline \multirow[t]{3}{*}{ Capacidade Adaptativa } & Muito limitada & 3 & 2 \\
\hline & Parcialmente limitada & 6 & 5 \\
\hline & Sem limitações & 1 & 3 \\
\hline \multirow{3}{*}{$\begin{array}{l}\text { Avaliação Global } \\
\text { (início) }\end{array}$} & Ajustamento psicossocial prejudicado & 2 & \\
\hline & Ajustamento psicossocial razoável & 8 & \\
\hline & Ajustamento psicossocial bom & 0 & \\
\hline \multirow{3}{*}{$\begin{array}{l}\text { Avaliação Global } \\
\text { (término) }\end{array}$} & Piorou & & 0 \\
\hline & Manteve-se sem alteração & & 6 \\
\hline & melhorou & & 4 \\
\hline
\end{tabular}


Ao início do grupo, a avaliação indicou que, em relação ao aspecto afetivorelacional, os pacientes ou encontravam-se com muitas dificuldades ou com alguma dificuldade para lidar com seus relacionamentos sociais e ou familiares, não havendo, segundo o ponto de vista médico, nenhum paciente que se encontrava sem dificuldades neste aspecto. Quanto ao aspecto produtivo, apenas três pacientes foram avaliados como sem dificuldades, sendo que a maioria deles indicava possuir alguma dificuldade no exercício de atividades produtivas e regulares. Em relação ao aspecto sócio-cultural, nenhum paciente pareceu possuir muitas dificuldades para conviver com as regras e valores do ambiente em que vivem, mas a maioria deles pareceu possuir alguma dificuldade em relação a este aspecto. Apenas um paciente foi avaliado como não tendo nenhuma dificuldade quanto a este aspecto sócio-cultural. Em termos da capacidade adaptativa quando do início do grupo, a maioria dos pacientes parecia sofrer uma limitação parcial nesta capacidade em função do quadro clínico apresentado. Apenas três pacientes foram avaliados como tendo sua capacidade adaptativa muito limitada por seu quadro clínico, e outros dois pareciam não sofrer limitação alguma em função do quadro que apresentavam. Por fim, a avaliação global ao início do grupo indicou que nenhum paciente encontrava-se com um bom ajustamento psicossocial, a maioria deles apresentando um ajustamento razoável. Apenas dois pacientes foram avaliados como tendo suas condições gerais indicativas de um ajustamento psicossocial prejudicado.

Estes dados apontam para a presença de dificuldades de adaptação na maioria dos aspectos avaliados no momento de encaminhamento para o grupo, o que é indicativo de prejuízo no nível de funcionamento destes pacientes.

Ao término do grupo, a mesma avaliação indicou que, em relação ao aspecto afetivo-relacional, metade dos pacientes encontravam-se com alguma dificuldade para lidar com seus relacionamentos sociais e ou familiares, havendo, segundo o ponto de vista médico, apenas dois pacientes que se encontravam sem dificuldades neste aspecto. Outros três pacientes indicaram possuir muitas dificuldades em seus relacionamentos familiares ou sociais. Quanto ao aspecto produtivo, três pacientes foram avaliados como sem dificuldades para exercer atividades regulares e produtivas, sendo que a maioria deles indicou possuir alguma dificuldade no exercício de atividades produtivas e regulares. Apenas para um paciente a avaliação 
indicou incapacidade para exercer atividades produtivas regularmente. Em relação ao aspecto sócio-cultural, nenhum paciente pareceu possuir muitas dificuldades para conviver com as regras e valores do ambiente em que vivem, sendo que parte deles pareceu possuir alguma dificuldade em relação a este aspecto, e outros foram avaliados como sem nenhuma dificuldade ao término do grupo. Quanto à avaliação de suas capacidades adaptativas, a maioria dos pacientes parecia continuar sofrendo uma limitação parcial nesta capacidade em função do quadro clínico apresentado. Apenas dois pacientes foram avaliados como tendo sua capacidade adaptativa muito limitada por seu quadro clínico, e outros três pareceram não sofrer limitação neste sentido. Por fim, a avaliação global ao término do grupo indicou que nenhum paciente encontrava-se pior em comparação ao momento de seu encaminhamento para o grupo, e seis deles apresentavam seu quadro sem alteração. Quatro pacientes foram avaliados como tendo suas condições gerais indicativas de uma melhora em comparação ao momento inicial do grupo.

Assim como no momento de encaminhamento para o grupo, a avaliação final demonstra que estes pacientes apresentavam prejuízos em seu nível de funcionamento, dada a presença de dificuldades adaptativas na maioria dos aspectos avaliados. A apresentação pormenorizada destes dados encontra-se no ANEXO 9, e permite a visão dos diferentes aspectos avaliados em cada paciente participante do grupo.

Por fim, apresentamos no QUADRO 7 uma descrição de alguns aspectos colhidos nas consultas aos prontuários, durante um período de quatro meses após o término do grupo. Neste, encontram-se algumas informações relativas à condutas tomadas junto a estes pacientes, bem como suas condições clínicas após este intervalo. Outros dados mais específicos, como as queixas principais, o tipo de medicação utilizada e os procedimentos tomados junto ao paciente ao longo do período de quatro meses, encontram-se descritos no ANEXO 10.

Conforme pode-se observar neste quadro, três pacientes receberam alta do serviço, e um deles abandonou o tratamento antes de seu término. Quatro dos dez pacientes que participaram do grupo seguiram em acompanhamento medicamentoso. Destes, apenas dois continuavam fazendo uso de medicação quatro meses após o grupo, um obteve alta da psiquiatria e um abandonou o tratamento por iniciativa 
pessoal. Outros dois pacientes receberam, no momento do término do grupo, indicação tanto para seguimento medicamentoso como para participação em outro grupo de apoio. Nenhum dos dois compareceu ao grupo e, em relação ao uso de medicação, um deles continuava fazendo uso passados quatro meses, e o outro havia interrompido o tratamento por conta própria, recebendo em seguida alta também em relação ao seguimento medicamentoso. Assim, percebe-se que a maioria dos participantes do grupo não continuou em nenhum tipo de atendimento após o período de quatro meses seguintes ao término do grupo, sendo que apenas três dos dez pacientes continuaram fazendo seguimento medicamentoso no serviço.

QUADRO 7- Informações sobre a continuação do atendimento dos pacientes no serviço, no seguimento de quatro meses após o término do grupo de apoio.

\begin{tabular}{|lclc|}
\hline \multicolumn{1}{|c}{$\begin{array}{c}\text { Conduta ao término } \\
\text { do grupo }\end{array}$} & $\begin{array}{c}\text { Freq. } \\
\mathbf{( N = 1 0 )}\end{array}$ & \multicolumn{1}{c|}{$\begin{array}{c}\text { Condições do paciente } \\
\text { após 4 meses }\end{array}$} & $\begin{array}{c}\text { Freq. } \\
\mathbf{( N = 1 0 )}\end{array}$ \\
\hline $\begin{array}{l}\text { Seguimento } \\
\text { medicamentoso }\end{array}$ & 4 & $\begin{array}{l}\text { Permanece em seguimento } \\
\text { medicamentoso } \\
\text { Alta } \\
\text { Abandono }\end{array}$ & 2 \\
& $\begin{array}{l}\text { Permanece apenas em } \\
\text { seguimento medicamentoso } \\
\text { Alta } \\
\text { medicamentoso }\end{array}$ & 2 & 1 \\
\hline Alta do serviço seguimento & 3 & & 1 \\
\hline $\begin{array}{l}\text { Abandono antes do } \\
\text { término do tratamento }\end{array}$ & 1 & & 1 \\
\hline
\end{tabular}

* não compareceram ao grupo

A análise dos dados obtidos por meio de consultas aos prontuários dos pacientes permite melhor caracterizar os pacientes do grupo, assim percebendo seus pontos de semelhança e diversidade. Isto favorece uma melhor compreensão da composição do grupo e das especificidades de um grupo constituído por este tipo de população. Em termos gerais, podemos afirmar, a partir da avaliação do nível de ajustamento psicossocial, a similaridade entre os pacientes do grupo no que se refere à presença de dificuldades adaptativas, que implicam em prejuízo no seu nível de funcionamento psicossocial. Porém, não se dispôs, neste estudo de outros instrumentos que permitam afirmar a homogeneidade do grupo em relação a outros aspectos, como características de personalidade e /ou recursos intrapsíquicos. 


\section{$\underline{4.3-\text { As sessões do grupo }}$}

O grupo teve 16 sessões semanais (quatro meses) de cerca de uma hora e meia de duração. A presença de cada paciente no grupo variou consideravelmente ao longo das dezesseis sessões, tendo desde pacientes que participaram de todos os encontros, como pacientes que faltaram com demasiada freqüência ou que abandonaram o tratamento. Em média, participaram do grupo cerca de sete pacientes por encontro. A sessão que teve maior freqüência de participação contou com a presença de nove pacientes, e a que teve menor freqüência com apenas quatro pacientes.

A figura abaixo (FIGURA 2) nos permite perceber a variação das presenças ao longo das sessões. Também apresentamos em anexo (ANEXO 11) uma tabela com a freqüência de cada participante ao longo das sessões do grupo.

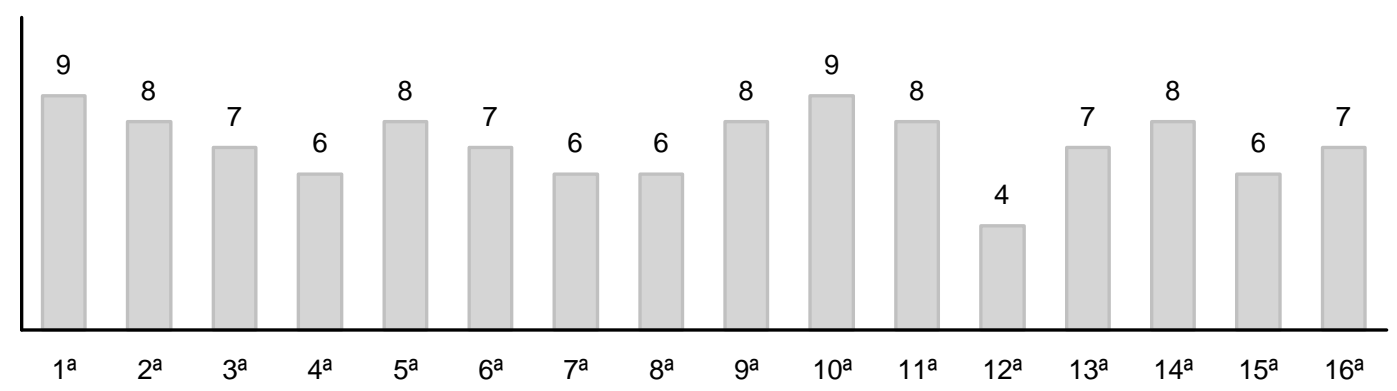

FIGURA O2 - Número de participantes presente em cada uma das sessões do grupo de apoio.

Apresentamos a seguir (QUADRO 8) a descrição do desenvolvimento das sessões, a partir de alguns eixos centrais da temática e da dinâmica do grupo tomados para análise, quais sejam: seus participantes; os assuntos e os temas discutidos; o padrão predominante de interação entre os membros; a tonalidade afetiva presente; a postura do coordenador; e impressões gerais da observadora. Tais aspectos foram considerados separadamente em cada uma das sessões do grupo. Este quadro, permitindo uma apreensão mais geral do desenvolvimento das sessões, mostra algumas das regularidades do processo deste grupo. 
QUADRO 8: Descrição do desenvolvimento do grupo a partir de alguns eixos centrais, relativos àtemática e àdinâmica de suas sessões

\begin{tabular}{|c|c|c|}
\hline Vértices/ sessões & $1^{\mathrm{a}}$ sessão & $2^{\mathrm{a}} \operatorname{sessão}$ \\
\hline Participantes & $\begin{array}{l}\text { Ana Maria, Marta, Irene, Marli, Valter, Estela, Roberta, João e } \\
\text { Rosilene }\end{array}$ & $\begin{array}{l}\text { Ana Maria, Marta, Irene, Marli, Valter, Estela, João, } \\
\text { Rosilene }\end{array}$ \\
\hline Assuntos & $\begin{array}{l}\text { Para evitar o aparecimento de sintomas ou por não conseguir enfrentar } \\
\text { situações difíceis e inesperadas, faz uso excessivo de calmantes; A } \\
\text { morte de pessoas queridas provocou grande sofrimento. }\end{array}$ & $\begin{array}{l}\text { Problemas de relacionamento com os pais influenciaram } \\
\text { no desenvolvimento das dificuldades psicológicas atuais; }\end{array}$ \\
\hline Temas discutidos & $\begin{array}{l}\text { Se não há um correspondente orgânico, qual a origem dos sintomas? } \\
\text { O sofrimento atual e os sintomas podem ser resultantes de } \\
\text { experiências traumáticas do passado. }\end{array}$ & $\begin{array}{l}\text { Dificuldades experimentadas em relações afetivas podem } \\
\text { ser responsáveis pela condição de sofrimento atual. }\end{array}$ \\
\hline $\begin{array}{l}\text { Padrão predominante } \\
\text { de interação entre os } \\
\text { membros }\end{array}$ & $\begin{array}{l}\text { Duas narrativas (Rosilene e Irene), orientam o movimento do grupo. } \\
\text { Participação ativa da maioria dos pacientes, que emitem concepções e } \\
\text { opiniões sobre os assuntos tratados. Posteriormente, longa narrativa de } \\
\text { Irene e escuta silenciosa do restante do grupo. }\end{array}$ & $\begin{array}{l}\text { Relato de uma paciente (Marta) sobre sua história de vida. } \\
\text { Postura silente do grupo, na maior parte do tempo. Nos } \\
\text { momentos de participação, esta se caracterizou por } \\
\text { conselhos e sugestões visando ajudá-la na resolução da } \\
\text { situação. }\end{array}$ \\
\hline Tonalidade afetiva & $\begin{array}{l}\text { Aparente ansiedade por descobrir a causa de seus problemas; apesar } \\
\text { da descontração inicial, há uma posterior apatia do grupo frente ao } \\
\text { relato de Irene sobre situações de seu passado. }\end{array}$ & $\begin{array}{l}\text { Busca de alternativas para o presente, seguida de uma } \\
\text { impotência frente ao contato com a impossibilidade de } \\
\text { alterar situações referidas como tendo no passado seus } \\
\text { determinantes. }\end{array}$ \\
\hline $\begin{array}{l}\text { Postura } \\
\text { do coordenador }\end{array}$ & $\begin{array}{l}\text { Apresentação do grupo e dos membros, acolhimento, investigação; } \\
\text { estimula a maior reflexão dos membros sobre as causas de seus } \\
\text { sintomas; valorização da participação do grupo. }\end{array}$ & $\begin{array}{l}\text { Escuta e investigação; apontamentos sobre a falta de } \\
\text { perspectiva de mudança trazida nos relatos. }\end{array}$ \\
\hline $\begin{array}{l}\text { Impressão } \\
\text { da Observadora }\end{array}$ & $\begin{array}{l}\text { Nos momentos iniciais, os membros se certificam da possibilidade de } \\
\text { confiar no grupo; passam a questionar a natureza de seus sintomas, } \\
\text { indagando sobre possíveis fatores psicológicos associados e } \\
\text { reforçando a influência de situações traumáticas na origem destes. }\end{array}$ & $\begin{array}{l}\text { Grupo assume a concepção de que situações traumáticas } \\
\text { determinaram suas condições atuais, assim não } \\
\text { percebendo, no presente, possibilidades de melhora. }\end{array}$ \\
\hline
\end{tabular}


Continuação..

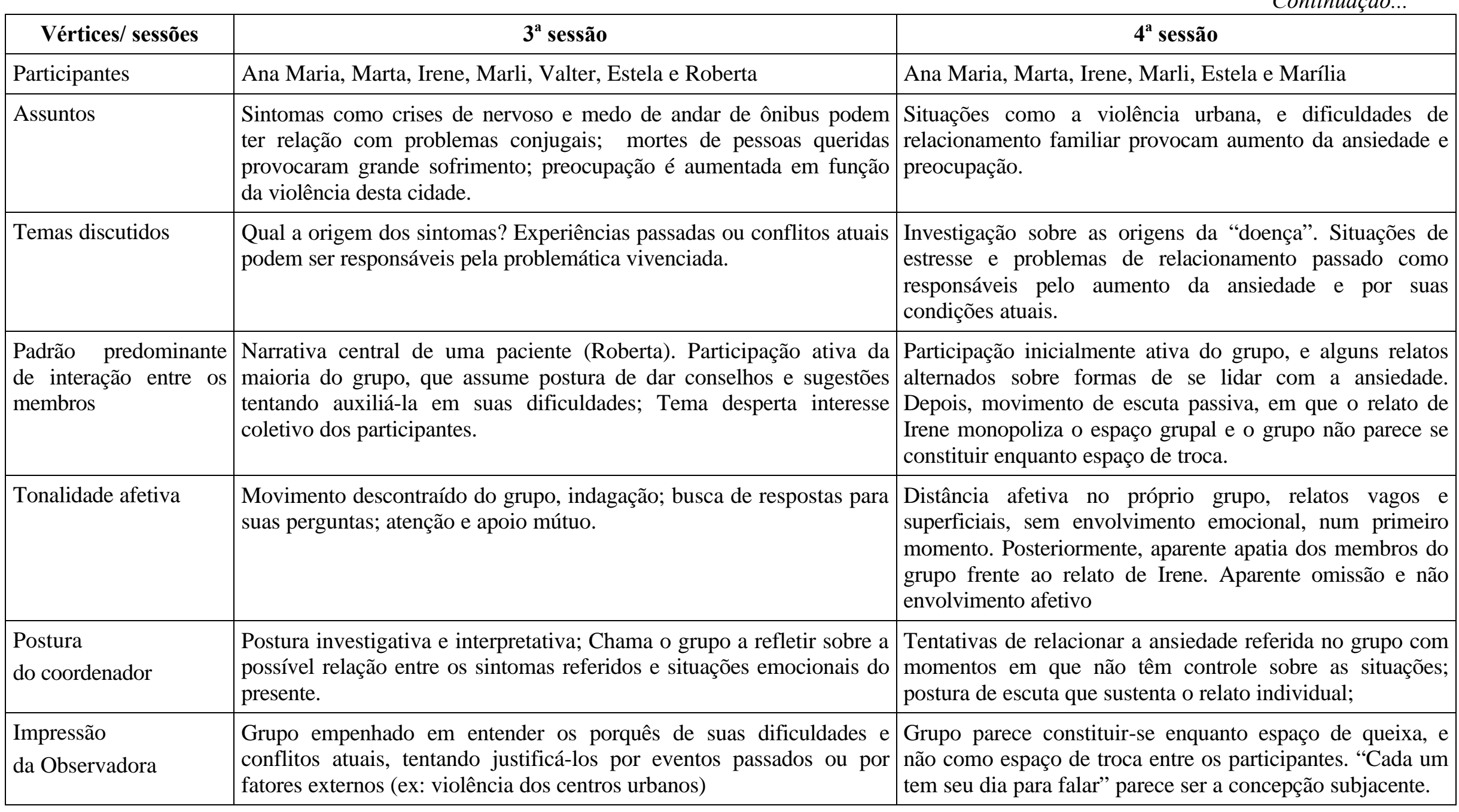


Continuação..

\begin{tabular}{|c|c|c|}
\hline & & \\
\hline Vértices/ sessões & $5^{\mathrm{a}}$ sessão & $6^{\mathrm{a}}$ sessão \\
\hline Participantes & Ana Maria, Marta, Irene, Marli, Valter, Roberta, João e Rosilene & Ana Maria, Marta, Irene, Marli, Valter, Estela e Marília \\
\hline Assuntos & $\begin{array}{l}\text { Desejo de entender a depressão e as alterações de humor a que está } \\
\text { sujeita }\end{array}$ & $\begin{array}{l}\text { Esquecimentos, visões - o que significam estes processos } \\
\text { mentais? O que é ser louco e o que os diferencia deles? }\end{array}$ \\
\hline Temas discutidos & $\begin{array}{l}\text { A depressão aparece independentemente de suas vontades; uso } \\
\text { abusivo dos medicamentos associado à dificuldades de enfrentamento } \\
\text { das situações de vida; o espaço grupal e suas possibilidades (como } \\
\text { devem utilizar o espaço do grupo?). }\end{array}$ & $\begin{array}{l}\text { Situações emocionais podem ser determinantes de } \\
\text { sintomas; o que é a doença mental e o que os diferencia } \\
\text { dos "loucos" que conhecem; o que significa participarem } \\
\text { de um grupo de tratamento; será que estão bem apenas } \\
\text { aparentemente? }\end{array}$ \\
\hline $\begin{array}{l}\text { Padrão predominante } \\
\text { de interação entre os } \\
\text { membros }\end{array}$ & $\begin{array}{l}\text { Narrativa inicial de uma paciente (Ana Maria) cortada por uma fala de } \\
\text { outra paciente (Rosilene), que apenas tem sua fala interrompida em } \\
\text { alguns momentos por intervenções do grupo, nas quais criticam e } \\
\text { confrontam suas atitudes. }\end{array}$ & $\begin{array}{l}\text { Embora baseado no relato inicial de Marli, a participação } \\
\text { do grupo parece mais democrática, com a maioria dos } \\
\text { participantes dando opiniões, relatando acontecimentos } \\
\text { similares e partilhando suas concepções sobre os assuntos. }\end{array}$ \\
\hline Tona & $\begin{array}{l}\text { De uma escuta passiva e desinteressada, à uma crescente irritação e } \\
\text { necessidade de convencer Rosilene das inadequações de suas atitudes. } \\
\text { Tensão e conflito aberto entre a maioria do grupo e Rosilene, em que } \\
\text { negociam o espaço do grupo, discutindo a melhor forma de utilizá-lo; }\end{array}$ & $\begin{array}{l}\text { Interesse em aprofundar a discussão, acompanhado de um } \\
\text { processo defensivo frente ao contato com a possibilidade } \\
\text { de que tenham aspectos doentios ou "loucos". }\end{array}$ \\
\hline $\begin{array}{l}\text { Postura } \\
\text { do coordenador }\end{array}$ & $\begin{array}{l}\text { Postura de escuta inicial substituída por intervenções confrontativas, } \\
\text { dirigidas à Rosilene, para que reflita sobre a inadequação de suas } \\
\text { atitudes; valorização do espaço do grupo, endossando a percepção da } \\
\text { maioria dos integrantes sobre a situação de conflito; sugestões de } \\
\text { reflexão quanto à diferenças individuais e as dificuldades de } \\
\text { relacionamento advindas destas diferenças. }\end{array}$ & $\begin{array}{l}\text { Investiga as concepções dos membros e estimula a } \\
\text { associação entre os sintomas e as situações emocionais que } \\
\text { vivenciam; explicita no grupo o "temor da loucura", } \\
\text { estimulando a discussão sobre a doença mental e sobre o } \\
\text { significado de suas participações no grupo. }\end{array}$ \\
\hline $\begin{array}{l}\text { Impressão } \\
\text { da Observadora }\end{array}$ & $\begin{array}{l}\text { A situação de conflito possibilita a reflexão e a caracterização das } \\
\text { possibilidades do espaço grupal, e a tensão aproxima os pacientes, } \\
\text { favorecendo a percepção no grupo das diferenças entre concepções, } \\
\text { valores e expectativas em relação ao tratamento. }\end{array}$ & $\begin{array}{l}\text { Participação mais coletiva do grupo, num tema que se } \\
\text { constitui como central: doença mental - o que os aproxima } \\
\text { desta realidade a partir do momento em que se percebem } \\
\text { necessitando de um tratamento psicológico. }\end{array}$ \\
\hline
\end{tabular}




\begin{tabular}{|c|c|c|}
\hline & & Continuação ... \\
\hline Participantes & Ana Maria, Marta, Marli, Estela, Marília e Rosilene & Ana Maria, Marta, Irene, Valter, João e Marília \\
\hline Assuntos & Dificuldades familiares estariam interferindo em suas condições atuais & $\begin{array}{l}\text { Dificuldades de relacionamento com a esposa doente } \\
\text { mental; dificuldades familiares. }\end{array}$ \\
\hline Temas discutidos & $\begin{array}{l}\text { Origem dos problemas situados em fatores externos, como } \\
\text { dificuldades de relacionamento passado / ou atual. }\end{array}$ & $\begin{array}{l}\text { As limitações impostas pela doença mental, suas origens e } \\
\text { a dificuldade de relacionamento advindas do convívio com } \\
\text { o paciente. }\end{array}$ \\
\hline Tonalidade afetiva & $\begin{array}{l}\text { Apatia do grupo; percepção de que a resolução de suas dificuldades } \\
\text { não depende deles; impotência. }\end{array}$ & $\begin{array}{l}\text { Sentimento de impotência; problemas situados nos outros, } \\
\text { e não em mim; "não tem solução". }\end{array}$ \\
\hline $\begin{array}{l}\text { Impressão } \\
\text { da Observadora }\end{array}$ & $\begin{array}{l}\text { Pacientes impermeáveis à sugestões do grupo e do coordenador; } \\
\text { utilização do espaço do grupo como espaço de queixa e desabafo, não } \\
\text { acreditando em possibilidades de melhora a partir do grupo. }\end{array}$ & $\begin{array}{l}\text { Discutem o tema "doença mental" de um lugar externo, } \\
\text { distanciando-se do lugar de paciente; percebem a } \\
\text { possibilidade de adoecer como decorrência das condições } \\
\text { de estresse atuais. }\end{array}$ \\
\hline
\end{tabular}




\begin{tabular}{|c|c|c|}
\hline & & Continuação... \\
\hline Vértices/ sessões & $9^{\mathrm{a}}$ sessão & $10^{\mathrm{a}}$ sessão \\
\hline Participantes & Ana Maria, Marta, Irene, Marli, Valter, Estela, Roberta, João & $\begin{array}{l}\text { Ana Maria, Marta, Irene, Marli, Valter, Estela, Roberta, } \\
\text { Marília e Rosilene }\end{array}$ \\
\hline Assuntos & $\begin{array}{l}\text { Situação familiar é percebida como impeditiva na realização de seus } \\
\text { projetos pessoais, e isso os deixa pior. }\end{array}$ & $\begin{array}{l}\text { Pouco trabalho ou trabalho excessivo, e experiências } \\
\text { afetivas passadas como responsáveis pelo aumento de } \\
\text { estresse e por suas condições atuais. }\end{array}$ \\
\hline Temas discutidos & $\begin{array}{l}\text { Possibilidade de melhora associada à resolução destas situações e } \\
\text { conflitos. }\end{array}$ & $\begin{array}{l}\text { Fatores externos (situações de vida atuais, ou experiências } \\
\text { passadas) como responsáveis pelas dificuldades que } \\
\text { vivenciam. }\end{array}$ \\
\hline $\begin{array}{l}\text { Padrão predominante } \\
\text { de interação entre os } \\
\text { membros }\end{array}$ & $\begin{array}{l}\text { Narrativa predominante de uma paciente (Ana Maria), e participação } \\
\text { de forma mais ativa de parte do grupo (três integrantes), sob a forma } \\
\text { de conselhos e sugestões. }\end{array}$ & $\begin{array}{l}\text { Tomando como referência o assunto levantado por Marta, } \\
\text { o grupo participa de modo ativo, referindo situações } \\
\text { similares, e questionando-se quanto a origem de suas } \\
\text { dificuldades atuais. }\end{array}$ \\
\hline Tonalidade afetiva & $\begin{array}{l}\text { Ansiedade inicial no grupo frente a condição da paciente. Crescente } \\
\text { frustração e impotência: "não depende de mim". Esperança de que as } \\
\text { dificuldades pessoais desapareçam com a resolução de alguns } \\
\text { problemas concretos. }\end{array}$ & $\begin{array}{l}\text { Ansiedade frente à falta de explicações sobre suas } \\
\text { condições atuais; não percebem possibilidades de mudança } \\
\text { ao situarem a origem destes problemas em histórias de vida } \\
\text { passadas ou em problemas concretos que não podem ser } \\
\text { resolvidos por eles mesmos. }\end{array}$ \\
\hline $\begin{array}{l}\text { Postura } \\
\text { do coordenador }\end{array}$ & $\begin{array}{l}\text { Acolhimento; sinaliza a deposição em fatores externos dos motivos de } \\
\text { suas dificuldades. }\end{array}$ & $\begin{array}{l}\text { Tentativa de colocar o grupo em contato com aspectos } \\
\text { emocionais envolvidos na doença; aponta a percepção do } \\
\text { grupo de que nada podem fazer para modificar suas } \\
\text { condições. }\end{array}$ \\
\hline $\begin{array}{l}\text { Impressão } \\
\text { da Observadora }\end{array}$ & $\begin{array}{l}\text { Parece existir um questionamento subjacente da possibilidade de ajuda } \\
\text { do grupo, já que situam em fatores externos as possibilidades de } \\
\text { mudança. }\end{array}$ & $\begin{array}{l}\text { Tentativa de desnaturalizar as explicações que traziam } \\
\text { sobre a origem de suas dificuldades, e assim potencializar } \\
\text { o grupo enquanto espaço de reflexão e mudança. }\end{array}$ \\
\hline
\end{tabular}


Continuação..

\begin{tabular}{|c|c|c|}
\hline \multirow{2}{*}{ Vértices/ sessões } & \multirow{2}{*}{$11^{\mathrm{a}}$ sessão } & \multirow{2}{*}{$12^{\mathrm{a}}$ sessão } \\
\hline & & \\
\hline Participantes & Ana Maria, Marta, Irene, Marli, Valter, Roberta, João e Marília & Ana Maria, Marta, Marli e Valter \\
\hline Assuntos & $\begin{array}{l}\text { Dificuldades econômicas influenciam em suas dificuldades } \\
\text { emocionais; sintomas de medo associados a lembranças de situações } \\
\text { difíceis experimentadas na infância. }\end{array}$ & Depressão aumentada por situações familiares. \\
\hline Temas discutidos & Sintomas e dificuldades atuais originadas em situações da infância & Origem da depressão. \\
\hline $\begin{array}{l}\text { Padrão predominante } \\
\text { de interação entre os } \\
\text { membros }\end{array}$ & $\begin{array}{l}\text { Participação ativa dos integrantes, que contam histórias sobre suas } \\
\text { experiências de infância e investigam, em alguns momentos a relação } \\
\text { entre estas e as dificuldades que apresentam na atualidade. }\end{array}$ & $\begin{array}{l}\text { Narrativa central de uma paciente (Ana Maria), que } \\
\text { mobiliza um silêncio inicial, e posteriormente, um } \\
\text { movimento atencioso e apoiador, em que os participantes } \\
\text { atuam dando conselhos e sugestões para que resolva sua } \\
\text { situação concretamente. }\end{array}$ \\
\hline Tonalidade afetiva & $\begin{array}{l}\text { Descontração; o contar história como justificativas de suas condições } \\
\text { atuais, tendo também função de alívio e de maior proximidade entre } \\
\text { os membros. }\end{array}$ & $\begin{array}{l}\text { Impotência e temor de não melhorar; percepção dos } \\
\text { problemas como sem solução; possibilidade de cura } \\
\text { depositada na resolução de problemas concretos; }\end{array}$ \\
\hline $\begin{array}{l}\text { Postura } \\
\text { do coordenador }\end{array}$ & $\begin{array}{l}\text { Apoio, escuta empática; tentativas de estimular a reflexão sobre a } \\
\text { relação entre os aspectos emocionais e os sintomas descritos pelos } \\
\text { pacientes }\end{array}$ & $\begin{array}{l}\text { Postura acolhedora e apoiadora; tentativas de incentivar a } \\
\text { tomada de uma decisão; sinaliza a ambivalência afetiva. }\end{array}$ \\
\hline $\begin{array}{l}\text { Impressão } \\
\text { da Observadora }\end{array}$ & $\begin{array}{l}\text { O contar histórias, parece ter cumprido duas funções: justificar a } \\
\text { "doença", assim não possibilitando uma reflexão sobre as } \\
\text { possibilidades de mudança, e de alívio da ansiedade no grupo } \\
\text { (preencher o espaço de reflexão com histórias passadas). }\end{array}$ & $\begin{array}{l}\text { Sentimento de isolamento presente nos momentos iniciais } \\
\text { do grupo, em que este não é percebido em seu potencial de } \\
\text { ajuda; medo de não melhorar e atribuição das } \\
\text { possibilidades de mudanças a fatores externos, que não } \\
\text { dependem deles para serem resolvidos. }\end{array}$ \\
\hline
\end{tabular}


Continuação..

\begin{tabular}{|c|c|c|}
\hline & & \\
\hline Vértices/ sessões & $13^{\mathrm{a}}$ sessão & $14^{\mathrm{a}}$ sessão \\
\hline Participantes & Ana Maria, Marta, Irene, Marli, Estela, Roberta e João & $\begin{array}{l}\text { Ana Maria, Marta, Irene, Valter, Estela, Roberta, Marília e } \\
\text { Rosilene }\end{array}$ \\
\hline Assuntos & $\begin{array}{l}\text { Preocupação com o aparecimento dos sintomas e não entendimento } \\
\text { sobre o mesmo; perda do amor e da atração sexual no relacionamento } \\
\text { conjugal e o surgimento de um novo amor; }\end{array}$ & $\begin{array}{l}\text { Dificuldades no relacionamento conjugal e dificuldade de } \\
\text { decisão. }\end{array}$ \\
\hline Temas discutidos & $\begin{array}{l}\text { Origem dos sintomas relacionado à vivência de situações de conflito } \\
\text { emocional (Se resolver o conflito, desaparecem os sintomas) }\end{array}$ & $\begin{array}{l}\text { Necessidade de tomar uma decisão para que as situações } \\
\text { de conflito familiares ou conjugais se resolvam }\end{array}$ \\
\hline $\begin{array}{l}\text { Padrão predominante } \\
\text { de interação entre os } \\
\text { membros }\end{array}$ & $\begin{array}{l}\text { Assunto trazido por uma paciente (Roberta) mostra-se de interesse } \\
\text { coletivo; grupo assume postura ativa, refletindo sobre o conflito da } \\
\text { paciente, relatando problemas semelhantes, levando alguns possíveis } \\
\text { fatores associados, e dando opiniões e sugestões para que resolvesse } \\
\text { sua situação emocional e seus sintomas desaparecessem. }\end{array}$ & $\begin{array}{l}\text { Grupo discute o assunto levantado por Roberta. Há } \\
\text { participação ativa dos membros, que se mostram ora } \\
\text { compreensivos, ora exigentes, cobrando que ela tome uma } \\
\text { atitude frente a sua situação; também sinalizam a sua } \\
\text { ambivalência afetiva; }\end{array}$ \\
\hline Tonalidade afetiva & $\begin{array}{l}\text { Descontração e curiosidade; apoio e compreensão; sensação de que o } \\
\text { problema tem solução; }\end{array}$ & $\begin{array}{l}\text { Esperança de que a resolução dos conflitos a partir do } \\
\text { grupo possibilite a melhora em suas condições, alternada } \\
\text { com a expectativa contrária de que os problemas se } \\
\text { resolvam magicamente, sem que precisem tomar decisões. }\end{array}$ \\
\hline $\begin{array}{l}\text { Postura } \\
\text { do coordenador }\end{array}$ & $\begin{array}{l}\text { Estimula a reflexão sobre a relação entre os sintomas e situações de } \\
\text { conflito, estimulando a exposição de assunto pessoais; mediação entre } \\
\text { os demais pacientes e Roberta, em alguns momentos ponderando as } \\
\text { afirmações e conselhos oferecidos; }\end{array}$ & $\begin{array}{l}\text { Apoio e acolhimento; sinaliza a expectativa de que seus } \\
\text { problemas se resolvam de forma "mágica", independente } \\
\text { de suas atitudes; atenta para a expectativa de que o grupo } \\
\text { lhes aponte a direção certa, decidindo sobre suas vidas. }\end{array}$ \\
\hline $\begin{array}{l}\text { Impressão } \\
\text { da Observadora }\end{array}$ & $\begin{array}{l}\text { Grupo descontraído, centrado na discussão do conflito apresentado por } \\
\text { uma paciente. Percepção de que a dissolução do conflito pode resultar } \\
\text { em seu bem estar geral; ânsia por resolver a situação rapidamente, em } \\
\text { função do término do grupo. }\end{array}$ & $\begin{array}{l}\text { Associação entre a resolução do conflito e e } \\
\text { desaparecimento dos sintomas e/ou dificuldades. }\end{array}$ \\
\hline
\end{tabular}




\begin{tabular}{|c|c|c|}
\hline & & Continuação... \\
\hline Vértices/ sessões & $15^{\mathrm{a}}$ sessão & $16^{\mathrm{a}}$ sessão \\
\hline Participantes & Ana Maria, Marta, Irene, Valter, Roberta e João & Ana Maria, Marta, Irene, Marli, Valter, Roberta e João \\
\hline Assuntos & Dificuldades em relacionamentos familiares podem fazê-los piorar. & Como percebem suas dificuldades ao término do grupo. \\
\hline Temas discutidos & Fatores relacionados à "doença”. & $\begin{array}{l}\text { Avaliação de suas participações e condições atuais, } \\
\text { comparadas ao início do grupo. }\end{array}$ \\
\hline $\begin{array}{l}\text { Padrão predominante } \\
\text { de interação entre os } \\
\text { membros }\end{array}$ & $\begin{array}{l}\text { Narrativa central de Marta, e o silêncio prevalece no grupo durante a } \\
\text { maior parte da sessão; posteriormente, participação ativa de um } \\
\text { membro do grupo, que assume postura de oposição e confronto das } \\
\text { narrativas desta paciente; outros integrantes interferem brevemente, } \\
\text { também com postura confrontadora; }\end{array}$ & $\begin{array}{l}\text { Fala não interativa, em que cada paciente expõe } \\
\text { separadamente o modo como percebe sua condição atual. }\end{array}$ \\
\hline Tonalidade afetiva & $\begin{array}{l}\text { Tensão no grupo, que parece discordar da postura assumida pela } \\
\text { paciente em sua vida; sentimentos de intolerância e rejeição; } \\
\text { necessidade de assumir a responsabilidade pela própria vida; }\end{array}$ & $\begin{array}{l}\text { Tristeza, desânimo, medo do desequilíbrio emocional e do } \\
\text { futuro. }\end{array}$ \\
\hline $\begin{array}{l}\text { Postura } \\
\text { do coordenador }\end{array}$ & $\begin{array}{l}\text { Confrontações, em que mostra a postura rígida da paciente e sua } \\
\text { impermeabilidade a novas concepções; sinaliza a percepção de que as } \\
\text { possibilidades de mudança estão nos outros. }\end{array}$ & $\begin{array}{l}\text { Postura diretiva, em que solicita a cada paciente } \\
\text { individualmente que avalie a sua própria participação no } \\
\text { grupo. }\end{array}$ \\
\hline $\begin{array}{l}\text { Impressão } \\
\text { da Observadora }\end{array}$ & $\begin{array}{l}\text { A rigidez da paciente provoca certa impotência no grupo, que têm } \\
\text { seus comentários invalidados; percebem sua limitação em ajudá-la. }\end{array}$ & $\begin{array}{l}\text { Alguns pacientes sensibilizam-se com o término do grupo, } \\
\text { ao sentirem que não melhoraram; outros parecem valorizar } \\
\text { o espaço do grupo, acreditando terem se beneficiado com o } \\
\text { tratamento. }\end{array}$ \\
\hline
\end{tabular}


Conforme podemos observar pela descrição das sessões do grupo, prevalece uma certa uniformidade nas sessões em relação à maioria dos aspectos apresentados.

Houve certa diversidade nos assuntos tratados, que refletiam, na maioria das vezes, questões relativas a dificuldades experimentadas pelos pacientes em seu momento atual. Porém, os temas tratados não tiveram grande variação ao longo das sessões do grupo, havendo predomínio de questionamentos acerca da origem da "doença" e dos sintomas e sobre os fatores determinantes de suas condições atuais.

Também o padrão de interação entre os membros pareceu não variar substancialmente ao longo das sessões. Geralmente, o grupo pareceu basear-se na narrativa central de um ou, no máximo, dois pacientes sobre suas situações de vida (atual ou passada). As intervenções dos demais durante estas narrativas variaram em função sobretudo da pessoa que falava e do tema discutido, predominando participações em forma de conselhos e sugestões para a resolução da problemática apresentada. Porém, na maioria das sessões, o grupo caracterizou-se por uma postura mais silenciosa.

A postura do coordenador pareceu objetivar, sobretudo, estimular a reflexão do grupo sobre as situações de conflito apresentadas pelos pacientes em suas narrativas e seus sintomas e dificuldades adaptativas. Suas intervenções ao longo das sessões foram objeto de uma análise sistematizada (análise do manejo do grupo), visando auxiliar na compreensão da natureza desse grupo estudado, e que será apresentada a seguir.

As impressões da observadora apontam predominantemente para a tentativa do grupo de estabelecer relações entre seus sintomas / dificuldades e os conflitos vivenciados, especificamente em seus relacionamentos afetivos (conjugais ou familiares). Os pacientes, em sua maioria, pareciam ávidos por compreender a razão de suas dificuldades, muitas vezes estabelecendo relações causais entre alguns fatores e depositando a expectativa de melhora na resolução de algumas situações que não dependiam de si mesmos.

Apresentamos, a seguir, a análise pormenorizada das intervenções do coordenador ao longo das sessões do grupo, objetivando descrever seu padrão de intervenção, assim compreendendo melhor a natureza do grupo em questão. 


\section{5 - O MANEJO DO GRUPO}

Apresentamos a seguir, a definição das categorias resultantes da análise de conteúdo da participação verbal do coordenador ao longo das sessões do grupo $(\mathrm{N}=1904)$.

1- REITERAÇÃO (Re) $\mathbf{N}=$ 920: Intervenção geralmente breve que consiste ou em resumir a comunicação do paciente ou em assinalar um elemento relevante desta, ou simplesmente em reproduzir as últimas palavras de modo a facilitar a continuação. Pode incluir ainda pequenos questionamentos que visam obter mais informações sobre algum assunto já referido pelo paciente em seu relato. Assim, a reiteração parece ter a função de sustentação da fala do paciente ou grupo. Exemplos:

1-) Marli: (conta de uma situação em que foi a uma Igreja, no centro da cidade, e caiu ao sair desta, perdendo os sentidos) (...) ai eu não sei se eu bati a cabeça.. coord: A senhora entrou na Igreja porque já estava sentindo mal?

Marli: Desci do ônibus porque já estava passando mal, parece que eu quis vomita.

Coord: já no ônibus?

Marli: É, no ônibus. Aí eu desci ali na catedral (...)

( $3^{\mathrm{a}}$ sessão, C14 e C15)

2-) Rosilene: (refere no grupo situação em que o marido brigou com a filha, e a agrediu fisicamente): Brigando com uma menina de quatorze anos! Brigando, meu marido é forte, ele é forte, ele pesa uns cento e dez quilos...

coord: Eles tavam brigando.

Rosilene: Ai chegou uma hora que eu me tranquei no quarto das meninas...

( $7^{\mathrm{a}}$ sessão, $\left.\mathrm{C} 48\right)$

3-) Ana Maria : (nos momentos iniciais do grupo) Posso fazer uma pergunta?

\section{Coord: Pode.}

Ana Maria: Porque todo dia antes de começar o grupo o senhor faz assim? (referindo-se ao movimento que o coordenador faz com as mãos)

(14 ${ }^{\mathrm{a}}$ sessão, C2). 
2-) INVESTIGAÇÃO (In) N=302: Intervenção que tem como objetivo obter informações suplementares ou provocar mais discussão de um tópico, mostrando ao grupo ou ao paciente que ele pode/ deve desenvolver melhor aquele aspecto. Assim, a intervenção investigativa parece ter a função de ampliar o foco da discussão, possibilitando a reflexão sobre o assunto em pauta ou a universalização no grupo de um assunto tratado por um paciente individualmente.

1-) Marta: (Fala de seu relacionamento problemático com a mãe, e comenta que acredita que a mãe é doente mental). Às vezes ela fala pra mim: "você é uma doente", e eu falo pra ela: "eu sou, por isso eu me trato". Agora ela não se trata, né?

coord: Você se acha uma pessoa doente?

Marta: Muito doente. Na alma, entendeu? Eu me acho mais doente do que milhares de pessoas.

(2 $2^{\mathrm{a}}$ sessão, C67)

2-) Ana Maria: ( iniciando a conversa no grupo após solicitação do coordenador) É engraçado, né, doutor, nós depressivos. Eu ultimamente estava assim, me sentindo ótima, né, estava vindo aqui e pensando "acho que eu nem preciso ir mais lá”. De repente começa de novo em crise (começa a chorar). Aquela crise, e aí chego à conclusão que uma vez depressiva, sempre depressivo, né, eu acho que é assim...Eu tô chegando a esta conclusão. Eu tô contente, tô me sentindo bem, de repente já começo de novo com esta vontade de chorar.

Coord: Mas você acha que é de repente?

Ana Maria: Ah, eu não sei...

(5 $5^{\text {a }}$ sessão, C19)

3-) Irene: (procede uma longa fala em que comenta sobre o problema levado ao grupo por Ana Maria, que queixava-se de não encontrar solução para os problemas da filha) - Eu não sei, eu não sei pois quem é médico aqui é o doutor P., mas (...) eu acho que cada família passa de um jeito. Ou é com filho pequeno que tá na escola, ou com moço, com moça. Às vezes tem uns moços que não dão trabalho igual mulher dá. Graças a Deus eu tenho uma com trinta...

coord: E como é que a senhora acha que ela vai sair desta enrascada?

Irene: Entrar num acordo com a filha e com o genro... 
3- ELUCIDAÇÃO (EI) N=236: Intervenção que atribui significado ou sentido à comunicação do paciente ou grupo, mostrando algo que não foi percebido por ele e possibilitando a ampliação da percepção sobre si mesmo ou sobre o assunto tratado. Exemplos:

1-) Marli: (contando que vê vultos, imagina que um gato passou por ela e também que sente-se mal andando de carro) - O meu marido queria, que ele recebeu um dinheiro agora, assim, ele falou assim: "vou comprar um carro para nós". Eu falei assim: "não compra não, pelo amor de Deus, não compra um carro não!”. Aí ele falou: "Mas por que? Pra nós sair nós dois!”. Eu falei: "Não compra. Não compra porque você vai comprar, vai lá pra aquela chácara, vai sujar de terra, eles vão entrar dentro, e eu não quero”. (...)

Coord: A senhora não quer que suja o carro.

Marli: Ah, não sei, não é que eu não quero que suja o carro, eu acho que aquele carro vai ser um transtorno, não quero. Vai entrar dentro daquele carro, vai sair, ai vem outro, bate e...

Coord: Mas vai bater?

Marli: Ah, sei lá, né, eu fico imaginando...

Coord: Ah! Imaginando pode acontecer tudo, né? Até o gato passar do lado... Marli: eu desci com ela dentro do carro, e desci lá na $A v$. Y. (segue dizendo que pegou uma carona com a colega do grupo e que teve medo de que algo acontecesse, e desceu antes do lugar que deveria).

(6 $6^{\mathrm{a}}$ sessão, C 53)

2-) (Ana Maria conta para o grupo sua insatisfação com a maneira como sua filha tem lidado com sua vida financeira. $\mathrm{O}$ grupo participa ativamente, dando sugestões e orientações sobre como percebem a situação. Ana Maria questiona se a ajuda que tem dado à filha tem de fato servido para alguma coisa. Valter aponta que ao ajudar a filha ela tem se prejudicado pessoalmente):

coord: Mas vejam, as formas como ela vai lidar com esta situação a gente não sabe. Mas o que a gente pode lidar aqui é com este sentimento que você trouxe de que por mais que você ajude, você viu que a ajuda toma outro rumo. Agora você precisa ajudar a sua filha a não depender mais de você. $E$ até quando você vai ficar abrindo mão do que você queria fazer. Isto é que esta te incomodando, isto é o que dá pra perceber no que você começa a falar Ana Maria: eu engordei depois de tudo isto.

Coord: Descompensou tudo...

(9 $9^{\mathrm{a}}$ sessão, C55) 
3-) Roberta: (comenta que perdeu a atração sexual pelo marido, não mais sentindo prazer com ele e que gostaria de reverter esta situação) (...) que nem eu tô procurando, aqui. Tô indo pra Igreja, pedindo pra Deus pra voltar o amor que eu tinha antes, que eu não posso continuar assim, que eu nem posso separar dele e arrumar outro por causa das crianças, né? (...) Ah, eu tenho esta esperança ainda (de voltar a sentir o que eu sentia antes).

Coord: $E$ você acha que isto depende de coisas que estão fora de você? Igreja, Deus (...) Você vai buscar ajuda, mas você vai buscar isto fora. Como a D. Marli está falando: o amor a Deus e ao marido não.

Roberta: Às vezes volta assim com o tempo, né, até acabar o tratamento, né?

(13 ${ }^{\mathrm{a}}$ sessão, C83)

4-) CONFRONTAÇÃO (Co) N=213: Intervenção que introduz um elemento de realidade que parece não considerado na fala e/ou atitude do paciente ou do grupo. Exemplos:

1-) João: Já que ninguém fala, eu vou falar alguma coisa agora. É... sobre a falta de paciência para lidar com o paciente. Minha esposa no caso. Ai, mas tem hora que ela chega a irritar! (...) (Segue relatando situações em que fica perdido, sem saber se as ações da esposa são intencionais ou se são consequiência de sua doença).

Coord: Eu achei interessante é que você falou no começo, né, "ter paciência de lidar com o paciente”. Como se ela fosse sua paciente.

João: Não, minha não. (...)

Coord: Você percebeu?

João: Ah, tá. Não é paciente. Eu sou o quê? Um guardião só...

(8 $8^{\mathrm{a}}$ sessão, C32 e C33).

2-) coord: (inicia uma frase e tem sua fala interrompida por Rosilene, que fala continuamente no grupo).

Rosilene: ... E isto eu não tomei calmante, diante de tudo isso, porque já fazia tempo que tomava calmante...

Coord: Você ouviu o que eu falei?

Rosilene: Não...

Coord: Eu acho que não ouviu...

Rosilene: Pode repetir por favor?

(1 ${ }^{\text {a }}$ sessão, C60) 
3-) Roberta: (Fala de sua preocupação com o término do grupo pois faltou muito e acredita que não vai melhorar até o fim. Refere queixas orgânicas e sua preocupação com seu estado de saúde). (...) eu penso que eu estou muito nova pra estar deste jeito, depois e quando eu tiver mais idade então? Eu já penso que quando eu tiver uma idade a mais assim, eu já vou estar, sei lá, doida... Pra falar... destes que interna, internado. Eu já começo a pensar: "Meu Deus, mas eu não quero passar por isto!' Tenho meus filhos pra criar, né, não posso passar por isto...

coord: Mas você não sabe se vai acontecer isto...

Roberta: Então, eu já penso um monte de coisas, todas estas coisas...

Coord: Veja, mas você está pensando até demais, né? Você quer até adivinhar o futuro!

Roberta: Ai, eu penso, porque eu tô pedindo muito a Deus pra me dar saúde...

(13 $3^{\mathrm{a}}$ sessão $\mathrm{C} 13$ e C14)

5- ENQUADRE (En) N=140: Intervenção relativa ao enquadre, à tarefa grupal e à regras de funcionamento do grupo. Inclui referências ao horário, à modalidade de participação, à possibilidades e limites do grupo, à faltas, à consultas individuais na psiquiatria e ao encerramento do grupo. Além disso, inclui a apresentação de si e do grupo, bem como o estímulo àparticipação verbal. Exemplos:

1-) coord: (estimulando a participação inicial no grupo) Quem quer começar?

(4 ${ }^{\mathrm{a}}$ sessão, C5)

2-) João: (Refere sua preocupação com o número de faltas que já teve no grupo). Aliás, a minha preocupação, que eu já até perguntei agora há pouco pra Carla, é se eu já deu três faltas sem falar nada. (...)

Coord: Em seguida?

João: Não, em seguida não, mas...

Coord: Não pode dar em seguida, em seguida é que complica. Três faltas seguidas sem avisar. (olha para Roberta) Tem gente aqui que deu três faltas seguidas.

(11 a sessão, C4 e C5)

3-) coord: (Após conversar com Ana Maria sobre sua situação na última sessão do grupo) Você tem consulta marcada? Que dia que é?

Ana Maria: dia 27...

(16 ${ }^{\mathrm{a}}$ sessão, C32) 
6-) AVALIAÇÃo (Av) N=34: Intervenção que geralmente expressa uma opinião do terapeuta sobre o paciente ou grupo, podendo conter também sugestões e conselhos quanto à conduta a ser tomada. Geralmente utilizada para avaliação do desempenho e da participação do paciente ou grupo durante a sessão ou grupo como um todo. Exemplos:

1-) coord: (ao término do grupo) (...) Vejam vocês, que por ser a primeira vez, este grupo até que foi bastante dinâmico, né, bastante produtivo, quase todo mundo, com raras exceções, fez alguma colocação (...)

(1 $1^{a}$ sessão, C67)

2-) Ana Maria: (Referindo-se ao incômodo de ter a filha morando com o genro e netos em sua casa) é, eu saía... eu ficava na biblioteca estudando, agora não posso fazer mais o que eu fazia.

Coord: Você abriu mão disso para cuidar dos netos.

Ana Maria: Foi.

Coord: Agora, eu acho que você precisa talvez conversar com ela, né?

Ana Maria: Ontem eu conversei com ela... (conta de como conversou com a filha).

( $9^{\mathrm{a}}$ sessão, C17)

3-) coord: (Avaliando a frequiência no grupo de cada paciente individualmente)

(...) Vamos passar para a D. Marli. A D. Marli também está de parabéns... Só

faltou duas vezes também, né?

(16 ${ }^{\mathrm{a}}$ sessão, C33)

7-) ORIENTAÇÃO (Or) N=26: Intervenção que oferece uma informação objetiva sobre algum assunto / tema tratado no grupo, assim clarificando algo que o paciente ou grupo desconhece. Exemplos:

1-) (Marta refere no grupo os diagnósticos que teria recebido durante seus tratamentos anteriores)

coord: A senhora quer saber o que que é esquizofrenia ou o que que ela tem?

Marli: Não, esta doença.

Coord: É uma doença da mente. Esquizofrenia é uma doença da mente. A senhora quer saber o que é esquizofrenia? É uma doença que ataca a cabeça das pessoas.

Marli: A pessoa vai pensando, pensando e ataca a cabeça?

Coord: Não é pensando... É que ataca o pensamento.

(2 $2^{\text {a }}$ sessão, C 93 e C94) 
2-) coord: (orientando o grupo sobre como responder ao questionário do incidente crítico) Todos os questionários vão ser deste jeito, as perguntas vão ser assim mesmo. A primeira pergunta quer saber de cada um de vocês o que nesta nossa conversa aqui de uma hora e meia, o que que cada um achou importante. Pode ser que os assuntos que vocês achem importantes sejam diferentes para cada um...

3-) Marli: (comentando que trabalhava muito em uma funerária da cidade). Era dezesseis horas que eu fazia, isto eu fiz quatro anos, ai depois eu. (...) Meu patrão nem gostava. Ele fazia aquilo porque na época ele enxergou a (minha) dificuldade e ele deixou, e ele falou que até é contra a lei.

Coord: é um risco para eles, se a senhora tivesse entrado na justiça e receber como hora extra... (10 a sessão, C 81).

8-) FALA INTERROMPIDA (FI) N=34: Tentativa de intervenção não concluída, por interrupção do paciente ou grupo durante a fala do coordenador. Exemplos:

1-) Marta: Não, eu não estou procurando (serviço) não, porque eu fiquei desestimulada para trabalhar, por isso eu estou desempregada este tempo todo. Fiquei desestimulada pra trabalhar, pra viver, pra tudo, por isto que eu tô desempregada este tempo todo.

Coord: como é que você imagina...

Rosilene: (falando ao mesmo tempo que o coordenador) Eu não entendi o que ela quis dizer com desestimulada... ( $2^{\mathrm{a}}$ sessão, C62)

2-) João: De trabalho no meu dia eu não fiz nada!

Coord: Não, eu não tô perguntando de trabalho. Eu queria saber...

João: você quer saber de uma seqüencia, de como foi o meu dia?

Coord: É, eu...

João: eu acordei às cinco e meia (segue contando de seu dia a dia)....

( $8^{\mathrm{a}}$ sessão, $\left.\mathrm{C} 41\right)$ 
3-) Valter: (comentando sobre a história de Roberta). Então veja, é interessante, que ela vivia sofrendo e gostava do marido. Depois, ela já estava cansada, sofrendo, tudo. E o marido resolveu mudar. E ai depois que ele mudou, que é muito bom pra ela, ao invés dela melhorar, a vida dela piora!

Coord: Ela continua passando mal! Então veja, isto é uma coisa, com esta colocação que o Valter trouxe...

Rosilene: Precisa dar umas férias para a vida conjugal! （10ª sessão, C143)

Apresentamos a seguir, as freqüências de aparecimento destas diferentes categorias de intervenção ao longo das sessões do grupo, o que nos permite melhor visualizar o modo como o grupo foi manejado.

Na FIGURA 3, apresentamos a distribuição percentual das intervenções do coordenador no grupo, considerando-se o conjunto das sessões. Em seguida, apresentamos esta distribuição considerando-se separadamente as intervenções dirigidas ao paciente ou ao grupo (FIGURA 4).

As FIGURAS 3 e 4 nos são bastante ilustrativas do conjunto das intervenções do coordenador ao longo do grupo. Conforme podemos observar na FIGURA 3, a maior parte das intervenções do coordenador são intervenções de "reiteração" (48\%), ou seja, intervenções que parecem ter como objetivo a sustentação da fala do paciente. Em seguida, questões de "investigação" durante a narrativa dos pacientes também foram utilizadas, embora com uma freqüência menos acentuada (16\%). Do total de intervenções durante as sessões, apenas 13\% foram de "confronto" à fala ou atitude dos pacientes, sobretudo a partir do fornecimento de alguns elementos de realidade desconsiderados pelo paciente ou grupo ao longo de sua narrativa. As demais intervenções apareceram com menor freqüência: enquadre (7\%); avaliação (2\%) e orientação (1\%). As intervenções do coordenador foram interrompidas pelos pacientes antes de serem concluídas em apenas $2 \%$.

Percebe-se, de modo geral, que o grupo parece ter sido coordenado de forma a permitir a livre expressão dos pacientes, também favorecendo um espaço para maior reflexão sobre suas problemáticas, a partir de questões de investigação e da 
postura elucidativa ou confrontadora do coordenador em alguns momentos. Intervenções mais diretivas e objetivas, como a "avaliação" e a "orientação", embora típicas em grupos de apoio desta natureza, foram quase inexistentes.

FIGURA 03 - Distribuição percentual das intervenções do coordenador no conjunto das sessões do grupo $(\mathrm{N}=1904)$ pelas categorias de intervenção.

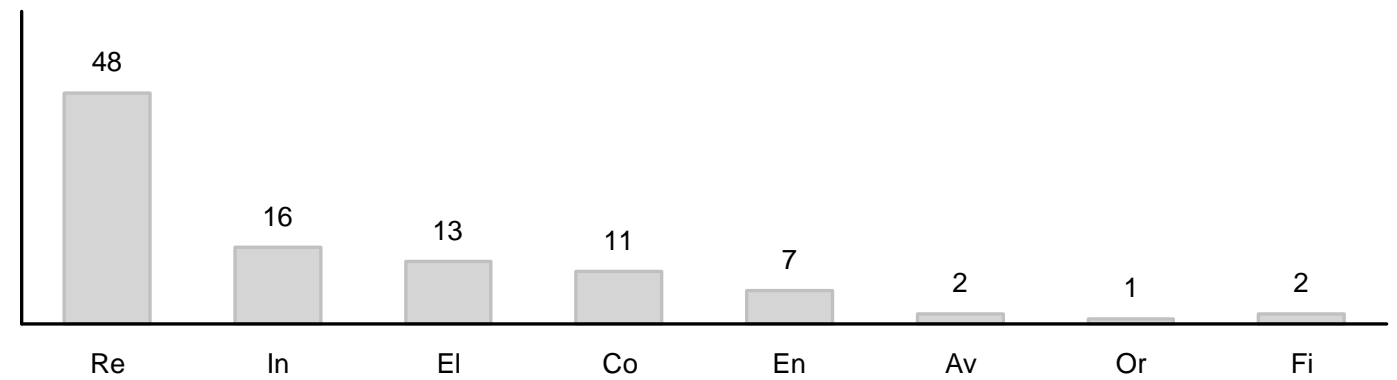

FIGURA 04 - Distribuição percentual das intervenções do coordenador dirigidas ao paciente $(\mathrm{P})$ ou ao grupo $(\mathrm{G})$ por categorias de intervenção, no conjunto das sessões do grupo.

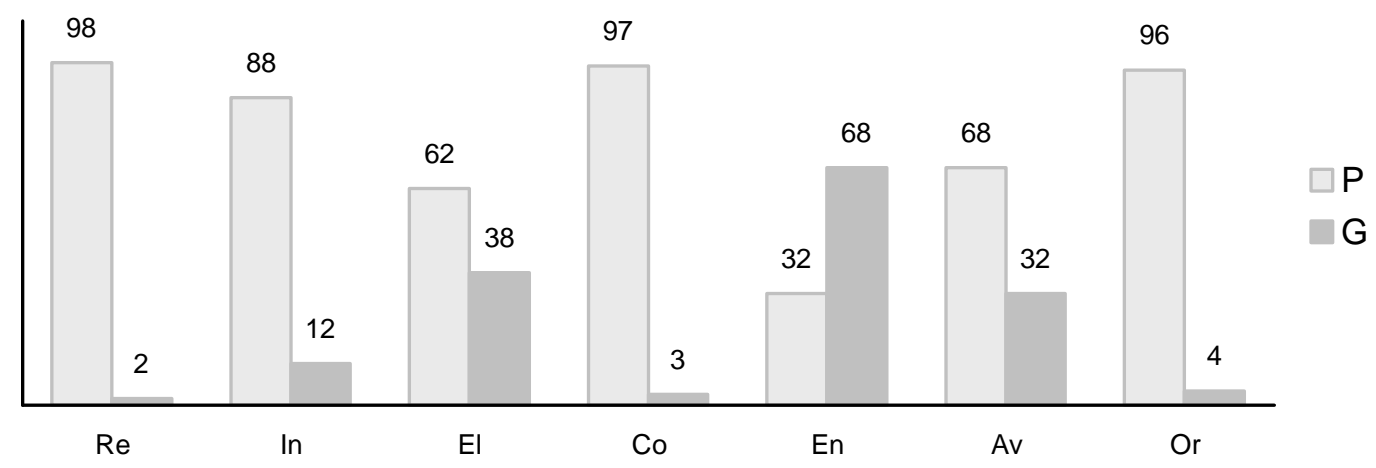

Podemos observar, ainda na FIGURA 4, que a maioria das intervenções do coordenador foi dirigida aos pacientes individualmente. Este dado parece coerente com o padrão predominante de interação no grupo, em que podemos observar a prevalência de narrativas centradas na fala de um único paciente durante quase toda a sessão. Este padrão de interação é bastante repetitivo ao longo dos encontros, como se o grupo trabalhasse com a concepção subjacente de que cada um tem o seu dia de se expor mais pessoalmente. 
O ANEXO 12 permite a visão das intervenções do coordenador considerandose cada sessão individualmente. Nota-se que há pouca variação entre as sessões, sendo que geralmente a ordem de freqüência das categorias de intervenção foi a mesma. Algumas variações podem ser melhor percebidas se considerarmos as particularidades das sessões, seja considerando seu contexto, seja considerando as interações do grupo neste dia específico. Por exemplo, se observarmos a primeira sessão do grupo, notamos uma elevação na porcentagem de intervenções de “enquadre" (24\%), se comparado à demais sessões. Entendemos esta variação em função do contexto do grupo, pois na primeira sessão as regras de funcionamento deste foram estabelecidas. $\mathrm{Na} 7^{\mathrm{a}}$ sessão do grupo, por exemplo, a porcentagem de intervenções de confronto também foi relativamente maior que nas demais sessões (21\%). Esta variação pode ser melhor compreendida em conjunção como o desenvolvimento da sessão, em que o coordenador esteve mais voltado a duas pacientes que pareciam acreditar que seus problemas dependiam unicamente de fatores externos, assim atentando-as para outros fatores não percebidos por elas e que poderiam influenciar suas condições atuais. Porém, as variações no modo de intervenção do coordenador foram mínimas predominando a similaridade da distribuição entre elas ao longo das sessões do grupo. 


\section{6 - A VIVÊNCIA DOS PARTICIPANTES: FATORES TERAPÊUTICOS E NÃO TERAPÊUTICOS DO GRUPO}

Apresentamos, a seguir, a definição das categorias derivadas da análise de conteúdo das respostas dos pacientes do grupo ao questionário do incidente crítico ( $\mathrm{N}=112$ ), seguidas de suas freqüências de aparecimento ao longo das sessões e de exemplos típicos de respostas que constituíram essas categorias de análise.

Conforme referimos anteriormente, esta classificação foi efetuada a partir de definições presentes na literatura sobre os fatores terapêuticos. De acordo com a análise da vivência dos participantes, entendemos estarem atuando no grupo os seguintes fatores terapêuticos: universalidade, aprendizagem vicária, instilação de esperança, altruísmo, aceitação, auto-revelação, orientação e catarse. Essa mesma análise, porém, também nos alertou para a necessidade de classificação de algumas respostas que remetem a sentidos relativos a vivências não terapêuticas, já que alguns pacientes remeteram a sentimentos de angústia, desesperança ou falta de envolvimento no grupo em suas respostas. Se considerarmos, segundo referido por CROUCH et al.(1994), fator terapêutico como um "elemento da terapia de grupo que contribui para melhorar a condição de um paciente e que pode ser decorrente das ações do terapeuta do grupo, dos outros membros do grupo e do próprio paciente" (p.271), podemos assumir, por contraposição, que fatores não terapêuticos são elementos que não contribuem para a melhora do paciente. Em nosso estudo, estes fatores não terapêuticos apresentam-se representados nas categorias distanciamento e desesperança.

Assim sendo, descrevemos abaixo as categorias derivadas de nossa análise:

1- UNIVERSALIDADE ( $\mathbf{N = 2 6 ) : ~ F o r a m ~ c l a s s i f i c a d a s ~ n e s t a ~ c a t e g o r i a ~ r e s p o s t a s ~ e m ~ q u e ~}$ o paciente reconhece que não é o único a ter problemas; percebe que outros membros do grupo têm problemas iguais ou maiores que os seus, o que reduz o seu senso de singularidade; e/ou experiência a sensação que não está sozinho com seus sentimentos e problemas.

Exemplo: “ O acontecimento mais importante de hoje foi de uma amiga nossa aqui do grupo, Roberta. O detalhe desse acontecimento foi da amiga Roberta sobre a situação entre ela e o marido. Eu senti que ela deve pensar mais um 
pouco para depois não se arrepender. Eu pensei que entre ela e o marido tendo uma conversa, eu penso que eles chegariam ao um entendimento. Eu fiz o que eu devia, falar, tentar fazer alguns carinhos, um bom diálogo seria muito bom. Este acontecimento foi muito importante para mim porque eu achava que era só eu que passava pórisso. Não. Tanto que essa nossa amiga esta passando pelo mesmo problema meu" (Estela, $13^{a}$ sessão).

$\mathrm{Ou}:$

Exemplo: "Foi D. Irene, contou sobre o filho, nora e neto. O filho não deu certo com o casamento. Ela ficou grávida e teve uma filha. A nora ficou doente e faleceu. Primeiro faleceu o marido de enfarte fuminante. E D. Irene sofreu muito mais agora com a separação da neta. Minha reação foi normal. Senti como se tivesse no lugar dela. Pensei, tive muita dó dela. Eu fiquei ouvindo ela falar. Eu achei importante porque às vezes eu acho que o meu problema é muito pequeno perto do dela" (Marília, $4^{a}$ sessão).

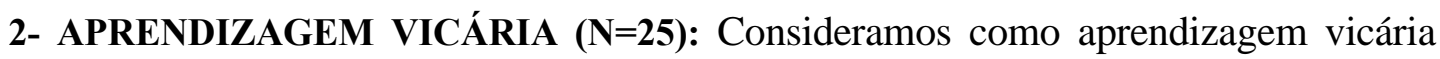
quando o paciente refere vivenciar algo de valor para si mesmo, através da observação de outros membros do grupo ou do terapeuta - seja por se identificar com a experiência de terapia de outro paciente, seja por reconhecer modelos de comportamento do terapeuta ou de outros membros a imitar, ou ainda, por perceber algumas atitudes ou comportamentos negativos em outros membros a não imitar. Consideramos também, respostas em que o paciente refere ter se reassegurado de suas concepções/ motivações/ atitudes através da observação de outro membro no grupo. Assim, o elemento comum nestas respostas é aprendizagem através da observação de outro membro do grupo.

Exemplo: "Cada uma pessoa no grupo espesou (expressou) sua melhora e o medico também pode espresar (expressar) as pessoas que necessita de mais tratamento no proximo grupo, por perguntar se a pessoa quer participar nos proximos grupos. Achei interessante a Roberta, ela não tem poblema de saude, mas ela tem que tomar uma decição (decisão) na vida dela, porque ela já sofreu muitos anos atras. E agora ela cançou, e tem uma outra pessoa na sua vida, e isto atormenta muito ela. Eu pude ver quando começou o grupo e quando terminou, e por isso que tirei uma concrução (conclusão), que a maioria das pessoas não sabem o que tem, e que nem todos tem doença. A maior parte das pessoas tem é problemas e que não esta sabendo como resolver ou lidar com 
eles. (foi importante) porque eu pude aprender do médico como ter muita calma e ele é muito lento, até no falar e não dar opinião propria, e não disse de que modo a pessoa deve fazer ou não. Fica a vontade de cada pessoa o que fazer. Talves ouvir e não interferir talves seja o melhor modo de ajudar o pasiente. E isto vou tentar colocar em prática e usar a calma do medico. Isto tem me ajudado e vai me ajudar muito. Obrigado" (Valter, $16^{a}$ sessão).

$\mathrm{Ou}$

Exemplo: "O relato de Irene do relacionamento difícil com sua nora. E Marli que falou alguma coisa sobre relacionamento também, mas com vizinhos. Irene começou falando dos medos e acabou contando das preocupações e sofrimento que teve com sua nora. Falou das brigas, verdadeira guerra entre uma e outra, e por fim a nora morreu vítima de HIV. Falou também de sua preocupação com a neta. Eu ouvi com atenção. (Minha reação foi) normal. Eu achei que quando diz que foi egoísta em não ter ido visitar a nora, ela talvez tenha remorso e isso faz com que ela sofra, mesmo que não admita. (Este acontecimento foi importante porque) acho que a coisa mais linda que existe no ser humano é a capacidade de perdoar, é também muito difícil. Já passei por experiências tristes que me fez sofrer muito, mas para meu bem e de quem me maguou eu consegui perdoar. Acho que a mágua e e rancor faz muito mal para nossa alma. Eu quero ser feliz e fazer as pessoas que estão a minha volta também”. (Ana Maria, 4 'sessão).

3- DISTANCIAMENTO (N=14): Considerou-se como distanciamento afetivo respostas em que o paciente denotou não ter sido envolvido com o material abordado no grupo, expressando: não ter achado o grupo importante em nenhum aspecto, julgando que este não atingiu seu objetivo; um relato sobre um acontecimento do grupo, mas feito de um lugar de observador externo; uma reação negativa ao assunto tratado no grupo, irritando-se com a pessoa que falava ou com o conteúdo de sua narrativa; ou ainda, uma reação negativa ao modo como o grupo respondeu à suas demandas, sentindo-se não compreendido.

Exemplo: "Hoje não achei nada importante. Há muito tempo que nada pra mim tem sido importante; quase nada acho graça” (Marta, I' sessão).

$\mathrm{Ou}$

Exemplo: "(O acontecimento mais importante foi) o Sr. José (o nome correto é João) com problemas na vida conjugal. Ele queixou que já está cansando das 
tarefas excessivas e está perdendo a paciência. Uma senhora do grupo tentou animá-lo e confortá-lo. (A minha reação foi que) eu senti que ele está perdendo a paciência de lidar com o problema de sua esposa. Penso que ele deve dialogar mais vezes com sua esposa. Eu só pude ouvi-lo. (Não respondeu ao por quê de ter achado este acontecimento importante)" (Marta, 8 sessão).

$\mathrm{Ou}$

Exemplo: "Sinceramente não tive nenhum interesse no assunto que a Marta abordou. Não tenho paciência, nem conhecimento da vida da Marta para tirar uma conclusão, não sei de doença nem da estrutura familiar. Fiquei quieto, não queria comentar o assunto, me senti inútil, pensei que iria perder tempo em falar alguma coisa, por que esta estória de religião enxe o saco. Quando a religião, digo, quando qualquer fanatismo toma uma pessoa é muito difícil perceber a realidade e cada um passa a ter a sua verdade. Não tenho paciência com isso. Não vim no grupo para discutir com ninguém, volto cansado e desgastado, prefiro assuntos mais envolventes e coletivos. Remédios, igreja, perdão não são meus assuntos preferidos. Tchau”. (João, $15^{a}$ sessão).

4- DESESPERANÇA ( $\mathbf{N}=\mathbf{1 0})$ : Esta categoria agrupa respostas em que os pacientes referem um sentimento de angústia a partir de sua participação no grupo. Nestas, os pacientes apontam ou um sentimento de que seus problemas não têm solução, ou a percepção de si mesmos como impotentes frente ao seu quadro clínico atual, assim não acreditando em possibilidades de melhora. Muitas vezes, esta percepção derivase da própria comparação entre sua condição e a de outros membros do grupo, evidenciando sentimentos de inferioridade de incapacidade para acompanhar o desenvolvimento do grupo.

Exemplo: "Eu falei mais um pouco dos meus problemas. Eu falei do meu atual conflito. Estou ajudando a minha filha e família, mas isto está sendo muito difícil pra mim, não agüento mais, mas não sei como resolver isso, estou muito confusa sobre o que é certo ou errado. (A minha reação foi que) fico triste quando falo. Gostaria que tudo fosse diferente, não queria magoar ninguém, por isso eu sofro. Tenho que encontrar uma saída, sem machucar, sem ferir. Acho que não vou conseguir, seria impossivel uma atitude sem que isso acontessa. Não tenho coragem, porque amo demais. Nossa, hoje nem eu mesma estou me entendendo, que confusão na minha cabeça, isso é muito mal, estou com medo, não quero ficar doente”. (Ana Maria, $12^{a}$ sessão). 
Ou, ainda:

Exemplo: (paciente pede que eu escreva, pois não consegue responder). " $E u$ gosto quando aquele homem fala, parece que ele vai a fundo, tem coisas que a gente não consegue e que ele consegue, mas eu não lembro direito o que ele falou - mas sei que ele fala coisas importantes. Vejo que ele entende de um jeito diferente que eu não sou capaz. (Este acontecimento) foi quando Roberta falou que o trabalho é que estava cansando ela, e como o médico fala, que é emocional, né? Foi o que ele falou. Porque eu acho que o cansaço também é da mente. Hoje eu custei a agüentar o grupo, estava achando ruim, comecei a suar frio, a passar mal. Desde que cheguei não estava sentindo bem, não sei achar onde é que estava meu mal estar, não era por causa das pessoas. (Este acontecimento foi importante) porque ele entende o que o médico fala e eu não. E nem às vezes o que a Rosilene fala, ela mistura tudo" (Marli, $10^{a}$ sessão).

5- INSTILAÇÃO DE ESPERANÇA (N=08): Considerou-se nesta categoria respostas que denotam um otimismo do paciente sobre seu progresso a partir do tratamento na terapia de grupo, seja pela observação de sua própria melhora, seja pela observação da melhora na condição de outros membros do grupo. Assim, o paciente parece acreditar no seu potencial para melhorar, ao ver que outros membros do grupo melhoram ou estão melhorando, ou por observar a sua própria condição atual comparada a outros momentos de sua vida, assim valorizando a utilidade terapêutica do grupo.

Exemplo: "O acontecimento mais importante é ter conhecido novos amigos. $O$ acontecimento de hoje foram trêz pessoas que falaram coisas muito importantes para mim. A única coisa que eu senti (foi) muito feliz. Apesar de tudo eu não fiz nada hoje. O que eu pensei que fosse alguma coisa mais dificieis (difícil), pra mim foi um pouco sim, mas eu vou conseguir vencer. (Este acontecimento foi importante) porque eu sendo uma pessoa muito fechada, para mim foi muito importante. Às vezes eu quero falar alguma coisa mais (mas) eu não consigo. Mais (mas) devagar eu chego lá". (Estela, $1^{a}$ sessão).

$\mathrm{Ou}$

Exemplo: "O mais importante no grupo de hoje, é que passei a saber, todos os colegas tem um assunto diferente para frequentar o grupo Achei muito bom. (O acontecimento foi que) D. Ana Maria, pessoa do grupo, estava muito depressiva, como muito choro e ai é que a gente analisa a vida de cada um no dia a dia. A minha reação foi normal, porque já passei a entender como são as 
coisas. Eu me senti muito bem com a ajuda do Dr. P. e da Dra. Carla, e vendo as pessoas um pouco mais bem do que quando no começo do grupo. $O$ importante para mim porque hoje me sinto bem melhor do que nos meses passado anteriores, estou muito grata. Obrigada, etc (Irene, $16^{a}$ sessão).

6- ALTRUí́SMO ( $\mathbf{N = 0 7 ) : ~ A g r u p a m o s ~ n e s t a ~ c a t e g o r i a ~ r e s p o s t a s ~ e m ~ q u e ~ o ~ p a c i e n t e ~}$ mostra-se sensível à̀ dificuldades / problemas / limites de outro membro do grupo, sentindo desejo de ajudá-lo ou efetivamente fazendo algo para ajudá-lo no contexto do grupo. Nestes casos, sentir-se útil e necessário para outro membro do grupo, parece mobilizar um sentimento positivo para o próprio paciente. As formas de ajuda foram indicadas como: oferecer apoio, segurança, sugestões ou comentários para ajudar outros membros do grupo; compartilhar problemas similares com o propósito de ajudar outros membros do grupo; poder esquecer de si mesmo em favor de outro membro do grupo; e/ou reconhecer que quer fazer algo por outro membro do grupo.

Exemplo: "O acontecimento mais importante foi de uma amiga nossa aqui do grupo. Ela não sabe se a ajuda que ela esta dando pela filha está sendo bom ou ruim. $O$ detalhe deste acontecimento é sobre uma ajuda que ela esta fazendo pela filha. A pessoa involvida nesse assunto de hoje é a nossa amiga Ana Maria. Eu senti que o que ela deve fazer é chegar na filha e dizer que não dá mais para ajudar. Eu penso que ela esta sofrendo muito com isso. (Na minha situação) eu fiz o que eu achei que devia, dizer 'ó filha, não dá mais para eu olhar as crianças porque eu estou muito cansada'. Este acontecimento foi muito importante porque a gente vindo aqui, se abrindo com as pessoas, conversando, falando os problemas. E este assunto de hoje foi muito importante porque a nossa amiga Ana Maria esta passando por um momento muito dificil na vida dela. Nós aqui do grupo e todos conversando podemos nós ajudar a ela resolver esta situação" (Estela, $9^{a}$ sessão).

7- ACEITAÇÃO (N= 06): Nesta categoria, considerou-se respostas em que o paciente denota: experimentar um sentimento de pertencimento, acolhimento, amizade e conforto no grupo, assim podendo se revelar mais pessoalmente; sentir-se valorizado por outros membros do grupo; valorizar o apoio que o grupo lhe oferece; ou sentir-se aceito e entendido por outros membros do grupo. 
Exemplo: (paciente pede que eu escreva, pois não consegue escrever) "Aconteceu foi comigo. Fui eu que contei do meu problema, né, então não estou tendo uma explicação. O que mais chamou atenção é que no grupo falaram que eu tenho que tomar uma atitude, que eu tenho que ver o que eu quero, que eu tenho que parar para pensar. Que eu não estou doente. Só isto. Que falou mais foi a Estela e a D. Irene. (As pessoas do grupo) não fizeram nada, só falaram, né? O que eu pensei é que eu tenho que separar do meu marido, pensei que do lado desta pessoa eu vou ser feliz, eu vou melhorar. (Este acontecimento foi importante) porque as pessoas aqui são de confiança, que a gente pode confiar. São pessoas assim, que me dão apoio, né?" (Roberta, $14^{a}$ sessão)

8- AUTO-REVELAÇÃO (N=04): Nesta categoria, agrupou-se as respostas em que o paciente valorizou o ato de revelar informações pessoais ao grupo - podendo falar tanto sobre sua vida fora do grupo como de seu passado, de seus medos, dificuldades, ou problemas, ou mesmo de informações pessoais sobre acontecimentos ou sentimentos difíceis ou dolorosos.

Exemplo: “O mais importante é que hoje as minhas colega não tiverão assuntos muitos para falar, assuntos que nos aborrece. A mais falante foi eu, Irene. Este acontecimento foi por motivo do grupo que nos dar a oportunidade de falar, contar o passado que aborreceu tanto a minha vida. As pessoas envolvidas são minhas colegas do grupo, que tem pacienssia de ficar houvindo para dar suas opiniões sobre o assunto e a ajuda do De. P.. A minha reação foi controlavel, mas sim muito sofrimento. Me sentia amarrada, nervosa, pencei que ia ficar louca de tantas coisas que me passaram na minha cabeça. Acho que este acontecimento foi importante para mim e também para o Dr. P. e Dra. Carla, por ter a chance de falar o mutivo que estou freqüentando o grupo. Acho que é muito bom falar, não para criticar, mas para que as pessoas do grupo intende, e que eu sinta me bem. Eu me sinto como que eu tinha repartido este problema porque as vezes é muito para uma pessoa só como eu, Irene”. (Irene, $\left.4^{a} \operatorname{sess} \tilde{a} o\right)$. 
9- ORIENTAÇÃO $(\mathbf{N}=\mathbf{0 4})$ : Esta categoria contém respostas em que o paciente considerou com importante no grupo ter recebido conselhos, sugestões e orientação explícitos sobre seus problemas, tanto do terapeuta quanto de outros pacientes.

Exemplo: "Quando eu estava comentando aqueles problemas que eu estava com medo, logo quando cheguei, e a Ana Maria falou que eu não podia sentir assim, que quanto mais eu achasse que estivesse com medo, eu ia passar mais mal. O mais importante que eu escutei foi isso aí. Também quando eu comecei a falar do problema com meu marido, que queria separar, que D. Irene falou para eu ter paciência. O mais importante foi a resposta dela. Da primeira vez, eu senti, na hora, que eu fiquei nervosa, fiquei me segurando, parece que eu me fechei por dentro, fechada. Ai depois, com a D. Irene, eu já me senti mais calma na hora. O que eu pensei é que não era certo o que eu estava achando que era certo eu fazer. (Este acontecimento foi importante) pelas respostas que as pessoas me falaram. Porque um ajuda o outro. Pelas palavras que as pessoas me falaram, porque eu acho que conforta a gente. É que hoje é só o segundo dia que eu estou vindo aqui, então eu acho que por hoje é só”. (Roberta, $2^{a}$ sessão - resposta ditada redigida integralmente pela pesquisadora, pois a paciente alegou não saber escrever).

10- CATARSE (N=03): Nesta categoria, considerou-se respostas em que o paciente valorizou a liberação de sentimentos positivos ou negativos, relativos tanto a eventos de sua vida como de outros, tendo a função de trazer certa medida de alívio. Assim, estas respostas enfatizavam a liberação emocional, permitindo ao paciente expressar sentimentos como raiva, afeição, tristeza, ou pesar que eram previamente difíceis ou impossíveis de liberar, assim resultando numa sensação de alívio.

Exemplo: "Para mim foi importante porque falei sobre o assunto que estava me incomodando, precisava de falar. Este acontecimento foi minhas colegas do grupo e o Sr. João que espoes os problemas dele com a esposa e as família. Eu, Irene, e o Sr. João. Comessei a conversar e acabei falando dos meus problemas e fiquei aliviada sobre os assuntos que falei. A minha reação foi que me senti entrar no assunto que o Sr. João falava e acabei falando sobre os meus problemas mais uma vez. Senti aliviada, pensei que nunca iria falar este assunto que falei sobre os meus problemas, é mais a gente ter uma oportunidade para que a gente fala sobre o assunto" (Irene, 8 sessão). 
11- NÃO CLASSIFICÁVEIS (N=05): Foram consideradas como não classificáveis as respostas dos pacientes que não traziam nenhum dos significados pertencentes æ̀ categorias já existentes dos fatores terapêuticos ou aos outros sentidos derivados dessa análise. Foram considerados nessa categoria os QIC devolvidos em branco, os casos em que o paciente alegou não pode responder ao questionário ou quando o paciente não respondeu ao questionário, ou quando apenas referiu a importância do grupo - sem outros dados que pudessem significar sua resposta.

Exemplo: "É que hoje foi diferente, todo mundo falou igual, mas acho que foi importante" (Roberta, $16^{a}$ sessão).

Podemos observar que as categorias "catarse", "auto-revelação", "aceitação" e "instilação de esperança" apresentam definições similares à definições propostas por BLOCH et al. (1979) em seu "Manual de Classificação dos Fatores Terapêuticos", preservando os sentidos apresentados originalmente por estes autores. Por sua vez, as categorias "universalidade", aprendizagem vicária", "orientação" e "altruísmo" apresentam definições que se diferenciam, em alguns aspectos, das definições destes autores, seja por excluir alguns sentidos, seja por acrescentar outros, de acordo com a especificidade do material analisado. Ainda assim, parecem preservar o sentido geral destas categorias. Outras categorias, porém, precisaram ser criadas (distanciamento, desesperança) por contemplarem dimensões não terapêuticas do processo do grupo, e não referidas por esses autores em sua classificação original.

Foram colhidos um total de 112 (cento e doze) questionários de incidente crítico ao longo das sessões, e conforme pode-se observar na TABELA 1 a seguir, o aparecimento dos diferentes fatores durante o grupo foi bastante variável.

O fator terapêutico mais presente ao longo do grupo, segundo a análise das respostas dos pacientes ao QIC foi a universalidade (23\%), que apareceu em praticamente todas as sessões, seguido do fator aprendizagem vicária (22\%). Em seguida, o fator distanciamento foi o mais evidenciado (13\%), seguido do fator desesperança (9\%), ambos podendo ser caracterizados como fatores não terapêuticos. A categoria instilação de esperança apareceu em 7\% das respostas, seguida do fator altruísmo (6\%). Embora com menor incidência, a análise evidenciou ainda os fatores 
terapêuticos aceitação (5\%), auto-revelação (4\%) e orientação (3\%) operando em algumas das sessões do grupo. Apenas 4\% das respostas dos pacientes ao QIC foram consideradas não classificáveis.

A TABELA 2, por sua vez, permite a visualização da distribuição dos fatores terapêuticos e não terapêuticos considerando cada paciente individualmente. Conforme pode-se observar os pacientes valorizaram aspectos que nos remeteram a diferentes fatores. Ana Maria respondeu ao questionário denotando sentidos que remetem predominantemente ao fator terapêutico aprendizagem vicária $(\mathrm{N}=09)$, e também algumas de suas respostas evidenciam desesperança $(\mathrm{N}=04)$ ou distanciamento $(\mathrm{N}=02)$. Apenas um de seus questionários nos remete à instilação de esperança como fator terapêutico. Marta, por sua vez, teve suas respostas classificadas em várias das categorias dos fatores terapêuticos, tendo predominado a categoria distanciamento $(\mathrm{N}=06)$ na análise de suas respostas. Segundo nossa análise, para Irene o fator terapêutico que se mostrou mais presente foi o altruísmo $(\mathrm{N}=04)$, porém suas respostas encontram-se distribuídas em muitos dos outros fatores que estariam operando neste grupo. Para Valter, sentidos que remetem a aprendizagem vicária predominaram em suas respostas $(\mathrm{N}=08)$. Marli, no entanto apontou em suas respostas sentidos que nos remetem ao fator desesperança $(\mathrm{N}=04) \mathrm{e}$ universalidade $(\mathrm{N}=02)$, entre outros. Para Roberta, sentidos que nos remetem ao fator terapêutico orientação foram mais referidos, embora tenha apontado também outros sentidos, conforme se observa na distribuição de suas respostas na tabela. Estela apontou sentidos que nos sugerem ter sido a universalidade o fator mais importante em sua vivência no grupo $(\mathrm{N}=05)$, ainda que tenha apontado outros fatores terapêuticos. Também para João, parece ter sido a universalidade o fator predominante, ainda que tenha o distanciamento $(\mathrm{N}=02)$ feito parte de suas respostas. Também para Marília a universalidade foi a categoria mais presente em seus relatos $(\mathrm{N}=05)$ seguida da categoria aprendizagem vicária $(\mathrm{N}=02)$. Por fim, para Rosilene suas respostas remetiam a fatores diversos, como instilação de esperança, aceitação, orientação, sem o predomínio de nenhum deles especificamente.

Assim, conforme percebemos, os pacientes referem aspectos, a partir de sua experiência no grupo, que nos remetem tanto a fatores terapêuticos como a fatores não terapêuticos. 
TABELA 1- Distribuição das respostas dos pacientes ao QIC ao longo das sessões do grupo pelas categorias de análise dos fatores terapêuticos e não terapêuticos.

\begin{tabular}{c|c|c|c|c|c|c|c|c|c|c|c|c|c|c|c|c|c|c}
\hline CATEGORIA/ SESSÃO & $\mathbf{1}^{\mathbf{a}}$ & $\mathbf{2}^{\mathbf{a}}$ & $\mathbf{3}^{\mathbf{a}}$ & $\mathbf{4}^{\mathbf{a}}$ & $\mathbf{5}^{\mathbf{a}}$ & $\mathbf{6}^{\mathbf{a}}$ & $\mathbf{7}^{\mathbf{a}}$ & $\mathbf{8}^{\mathbf{a}}$ & $\mathbf{9}^{\mathbf{a}}$ & $\mathbf{1 0}$ & $\mathbf{1 1}^{\mathbf{a}}$ & $\mathbf{1 2}^{\mathbf{a}}$ & $\mathbf{1 3}^{\mathbf{a}}$ & $\mathbf{1 4}^{\mathbf{a}}$ & $\mathbf{1 5}^{\mathbf{a}}$ & $\mathbf{1 6}^{\mathbf{a}}$ & $\mathbf{F}$ & $\mathbf{\%}^{\mathbf{a}}$ \\
\hline UNIVERSALIDADE & 01 & 03 & 02 & 02 & 02 & 01 & 02 & 01 & 02 & 02 & 04 & - & 03 & - & 01 & - & 26 & $23 \%$ \\
\hline APRENDIZAGEM VICÁRIA & 02 & 02 & 02 & 02 & 02 & 02 & 02 & 02 & 01 & 02 & - & - & 01 & 02 & 02 & 01 & 25 & $22 \%$ \\
\hline DISTANCIAMENTO & 02 & - & 01 & - & 02 & - & 01 & 01 & - & - & - & 01 & 02 & - & 02 & 02 & 14 & $13 \%$ \\
\hline DESESPERANÇA & - & - & - & 01 & - & 01 & - & - & 02 & 01 & 01 & 02 & - & - & - & 02 & 10 & $9 \%$ \\
\hline INSTILAÇÃO DE ESPERANÇA & 01 & 01 & - & - & - & 01 & - & - & 01 & 01 & 01 & - & - & 01 & - & - & 08 & $7 \%$ \\
\hline ALTRUÍSMO & - & 01 & - & - & 01 & 01 & - & - & 01 & - & - & 01 & - & 02 & - & - & 07 & $6 \%$ \\
\hline ACEITAÇÃO & 03 & - & 1 & - & - & - & - & - & - & - & 01 & - & - & 01 & - & - & 06 & $5 \%$ \\
\hline AUTO-REVELAÇÃO & - & - & - & 01 & - & 01 & - & - & - & 01 & - & - & - & - & - & 01 & 04 & $4 \%$ \\
\hline ORIENTAÇÃO & - & - & 01 & - & 01 & - & - & - & - & 01 & - & - & 01 & - & - & - & 04 & $4 \%$ \\
\hline CATARSE & - & 01 & - & - & - & - & - & 02 & - & - & - & - & - & - & - & - & 03 & $3 \%$ \\
\hline NÃO CLASSIFICÁVEIS & - & - & - & - & - & - & 01 & - & 01 & 01 & 01 & - & - & - & - & 01 & 05 & $4 \%$ \\
\hline
\end{tabular}


TABELA 2: Distribuição das respostas de cada paciente do grupo ao QIC, pelas categorias de análise dos fatores terapêuticos e não terapêuticos.

\begin{tabular}{|c|c|c|c|c|c|c|c|c|c|c|c|c|}
\hline CATEGORIA/ PACIENTE & Ana Maria & Marta & Irene & $\begin{array}{c}\text { Valte } \\
\mathbf{r}\end{array}$ & $\underset{\mathbf{i}}{\operatorname{Marl}}$ & $\begin{array}{c}\text { Rober } \\
\text { ta }\end{array}$ & $\begin{array}{c}\text { Estel } \\
\mathbf{a}\end{array}$ & João & Marília & $\begin{array}{c}\text { Rosilen } \\
\text { e }\end{array}$ & $\mathbf{F}$ & $\%$ \\
\hline UNIVERSALIDADE & - & 03 & 03 & 01 & 03 & 02 & 05 & 04 & 05 & - & 26 & $23 \%$ \\
\hline APRENDIZAGEM VICÁRIA & 09 & 02 & - & 08 & 01 & 02 & 01 & - & 02 & - & 25 & $22 \%$ \\
\hline DISTANCIAMENTO & 02 & 06 & 01 & - & 02 & 01 & - & 02 & - & - & 14 & $13 \%$ \\
\hline DESESPERANÇA & 04 & - & - & 02 & 04 & - & - & - & - & - & 10 & $9 \%$ \\
\hline INSTILAÇÃO DE ESPERANÇA & 01 & 01 & 02 & - & 01 & - & 01 & - & - & 02 & 08 & $7 \%$ \\
\hline ALTRUÍSM0 & - & - & 04 & - & 01 & - & 02 & - & - & - & 07 & $6 \%$ \\
\hline ACEITAÇÃO & - & - & 03 & - & - & 01 & - & 01 & - & 01 & 06 & $5 \%$ \\
\hline AUTO-REVELAÇÃO & - & 02 & 01 & - & - & - & 01 & - & - & - & 04 & $4 \%$ \\
\hline ORIENTAÇÃO & - & - & - & - & - & 03 & - & - & - & 01 & 04 & $4 \%$ \\
\hline CATARSE & - & 01 & 01 & - & - & - & - & 01 & - & - & 03 & $3 \%$ \\
\hline NÃO CLASSIFICÁVEIS & - & 01 & - & 01 & - & 01 & - & 01 & - & 01 & 05 & $4 \%$ \\
\hline TOTAL & 16 & 16 & 15 & 12 & 12 & 10 & 10 & 09 & 07 & 05 & 112 & $100 \%$ \\
\hline
\end{tabular}




\section{7 - DISCUSSÃO}

Algumas considerações sobre o grupo objeto deste estudo podem ser agora realizadas, tendo em vista os dados apresentados, a saber: 1) a caracterização dos pacientes do grupo; 2) a descrição de suas sessões; 3) a descrição de seu manejo pelo coordenador; 4-) e os fatores terapêuticos e não terapêuticos vivenciados no grupo por seus participantes. Consideramos estes quatro vértices de análise como centrais no entendimento dos limites e possibilidades do grupo estudado, pois permitem uma melhor definição de sua natureza para além de sua simples denominação, sobretudo se tomados de modo complementar e inter-relacionado.

Assumimos como objetivo desse estudo compreender os limites e possibilidades de um grupo de apoio de curta duração com pacientes psiquiátricos, a partir da descrição de seu manejo e dos fatores terapêuticos e não terapêuticos presentes neste, a partir da percepção de seus participantes.

Ao longo deste estudo, pareceu-nos evidente a necessidade de refletir sobre alguns aspectos específicos deste grupo, para assim melhor delimitar o objeto de estudo. Questões como "por que o atendimento em grupo é utilizado neste contexto, e se dirige à pacientes psiquiátricos e ambulatorias", ou ainda, "o que faz um grupo ser considerado como grupo de apoio", nos pareceram fundamentais para a compreensão das especificidades do grupo estudado. Portanto, nessa discussão, pretendemos tentar compreender a natureza desse grupo tendo como base os resultados apresentados anteriormente e dando ênfase à maneira como essa prática grupal tem se constituído neste contexto.

Neste sentido, a caracterização dos participantes do grupo parece cumprir duas funções principais: responder à perguntas "quem são os integrantes deste grupo" ou "como o grupo foi constituído", e possibilitar o estabelecimento de relações entre as possibilidades oferecidas por esta modalidade de atendimento e as características da clientela atendida. Abordaremos, então, um primeiro aspecto que nos parece fundamental: os critérios que definiram a composição deste grupo de terapia específico.

Durante o desenvolvimento do estudo, esforços foram empreendidos na caracterização dos pacientes, conforme apresentamos anteriormente. Por meio de observações do grupo e por registros dos prontuários, concluímos que o grupo de 
apoio foi composto de modo a privilegiar alguma similaridade entre os diagnósticos clínicos de seus participantes - diagnósticos de transtornos diversos, em que os pacientes apresentam, em uma história de vida marcada por dificuldades variadas em seu ajustamento psicossocial, uma situação de crise. Assim, embora distintos, os diagnósticos apresentam em comum o fato de se referirem a quadros clínicos mantidos no tempo e caracterizados pela presença de determinados traços de personalidade e de padrões de relacionamento.

Do mesmo modo, se tomarmos os diagnósticos clínicos gerais dos participantes do grupo (transtornos de humor; transtornos neuróticos relacionados ao estresse e somatoformes; e transtorno típico de personalidade), segundo classificados pelo CID-10, verificamos que, a literatura especializada também os define como quadros mantidos no tempo e caracterizados por determinados traços de personalidade e padrões de reação mal adaptados (AZIMA, 1996; BROOK, 1996; SADOCK \& KAPLAN, 1996; KAPLAN, SADOCK \& GREBB (1997a); KAPLAN, SADOCK \& GREBB (1997b); CORDÁS, NARDI, MORENO \& CASTEL, 1997).

A vivência de uma situação de crise pelos pacientes, por sua vez, pode ser percebida a partir da única avaliação formal que o estudo envolveu, a saber, a avaliação sobre o nível de ajustamento psicossocial dos pacientes. Assim, entendendo funcionamento como capacidade de ajustamento psicossocial, concluímos pela existência de uma certa homogeneidade no grupo, já que em sua maioria, os pacientes apresentavam dificuldades adaptativas na maioria dos aspectos avaliados (afetivo-relacional, produtivo, sócio-cultural, capacidade adaptativa e avaliação global). Os dados descartam, assim, quadros de deterioração psíquica ou sérios comprometimentos, e sinalizam a presença de conflitos e de prejuízos na capacidade adaptativa na maior parte dos aspectos considerados nesta avaliação.

Consideramos que a avaliação geral destes pacientes guarda certa similaridade com o diagnóstico de "adaptação não eficaz moderada", com a vivência de uma situação de "crise", proposto por SIMON (s/d). Segundo este autor, em pacientes com este diagnóstico

“...a adaptação a alguns setores (ou a todos) é feita à base de soluções não muito gratificantes, embora lhe permitam estar de acordo com seus valores internos ou sócio culturais; ou as soluções adaptativas podem ser mais 
gratificantes, mas encaminhadas de tal forma que se sinta culpado ou ameaçado de represálias do ambiente. Quando em crise, seu comportamento torna-se menos previsível, podendo æ̀̀ vezes ceder a impulsos destrutivos, executando ações irracionais" (p.20).

Concordamos com Simon apud COSTA-ROSA (s/d) de que em uma situação de crise "há momentos em que fica suspensa a capacidade do psiquismo de dar respostas à situações críticas", de modo que a anterior estabilidade afetiva "é drasticamente confrontada por circunstâncias (internas ou externas ao sujeito) que sacodem a estabilidade afetiva, levando a mudanças bruscas e permanentes nos padrões de adaptação do sujeito" (p.16).

Concluímos, então, que os pacientes do grupo apresentam um comprometimento em sua capacidade adaptativa, porém não podemos precisar a intensidade deste comprometimento dada a diversidade de condições inseridas neste contexto. A observação dos pacientes através de suas participações no grupo, por sua vez, nos sugere que esta homogeneidade é relativa, sendo que podemos perceber algumas diferenças entre os pacientes, sobretudo em relação à força de ego e a padrões de relacionamento interpessoal. Porém, estas diferenças não foram avaliadas por instrumentos específicos, o que torna, por conseguinte, difícil definir a composição deste grupo em função de sua "homogeneidade" ou "heterogeneidade". A instituição não conta usualmente com outros critérios de avaliação dos pacientes, restringindo-se aos dados sobre evolução do paciente no serviço e seus diagnósticos clínicos para composição dos grupos e, sendo nosso propósito compreender os limites e possibilidades dessa intervenção nas condições naturais em que esta ocorre, essas avaliações não foram realizadas.

Também consideramos as anotações de prontuário como elementos importantes na compreensão dos critérios de seleção para o grupo. Nelas constam sobretudo registros da presença de sinais e sintomas, seguidos de uma proposição diagnóstica que em geral exclui a presença de comorbidade. Estes dados sugerem que os profissionais deste serviço parecem não dispor de outros elementos que permitam uma avaliação dos pacientes para além de um diagnóstico clínico. Porém, medidas de sinais e sintomas podem funcionar como critério suficiente na indicação para seguimento medicamentoso, mas não para a indicação de tratamento psicoterapêutico. Se os profissionais da instituição não dispõem de condições para 
efetuar outras avaliações, tais como avaliações de personalidade, do nível de funcionamento egóico do paciente ou dos padrões de relações interpessoais que usualmente estabelecem, provavelmente carecerão de dados fundamentais para uma seleção criteriosa no momento da indicação para tratamento psicoterápico.

CESARINO (1989) nos aponta que por muito tempo a psiquiatria tentou se afirmar como ciência centrando-se sobretudo no modelo médico-clínico. O surgimento dos psicotrópicos e das terapias de choque surgiam criando esperanças de que "uma postura exclusivamente médica fosse a saída para a psiquiatria" (p.04). Segundo este autor, seguidamente às mudanças nas políticas de atenção em saúde, os ambulatórios de saúde mental tinham estrutura interna rígida, antiga e autoritária, em que predominava como método de trabalho exclusivamente o atendimento médico e medicamentoso. Eram poucos os profissionais de outras áreas, sendo quase ausente a integração entre eles e a programação dos tratamentos. Assim, esta disputa entre o modelo clínico / medicamentoso e as práticas psicoterápicas parece ter sido um dos fatores responsáveis pelo crescente emprego de medicações em detrimento da evolução de outras modalidades de tratamento. Isso parece constituir-se ainda como realidade atual, se considerarmos que nossas fontes de dados, ao mesmo tempo que remetem ao nosso contexto de estudo, não se constituem como um fato isolado.

Retomando os procedimentos de seleção e triagem do grupo, temos que os pacientes foram encaminhados para serem avaliados para integrarem o grupo através de psiquiatras do próprio serviço. A partir disto, o coordenador realizava uma entrevista de triagem com cada paciente, verificando a necessidade do seguimento psicoterapêutico, indicando-o ou não para o grupo de apoio. Contudo, as possibilidades de atendimento psicoterápico nesta instituição não são vastas, e um dos aspectos altamente incentivados no cotidiano das instituições públicas são as práticas psicoterápicas grupais. Além dos atendimentos em grupo (de apoio ou psicoterapêutico, conforme denominado neste serviço), e das poucas psicoterapias individuais, geralmente indicadas em situações críticas, não restam outras possibilidades. Assim, o profissional é colocado em uma difícil posição, em que para poder atender à demanda de pacientes que buscam ajuda, pode apenas oferecer a forma de psicoterapia disponível na instituição. 
Tendo em vista estes aspectos, se considerarmos apenas diagnósticos clínicos, a conduta do profissional da instituição parece consoante com o que nos aponta a literatura - onde se considera que pacientes com diagnósticos de transtornos (diversos) têm indicação para tratamento psicoterápico e para seguimento medicamentoso nas situações de crise (KAPLAN, SADOCK \& GREBB,1997c). Contudo, a literatura aponta a existência de uma ampla variedade de tratamentos em psicoterapia, que variam tanto em função dos tipos de tratamento (modalidades de intervenção - individual ou em grupo, tempo de duração da intervenção) como das diferentes vertentes teóricas existentes (CORDIOLLI, 1998).

Dentre estas diversas formas de atendimento em psicoterapia, encontram-se as psicoterapias de grupo, sendo que cada uma de suas modalidades de intervenção é definida por determinados objetivos e alcance terapêutico. Isto implica na necessidade de que as diferentes práticas sejam consideradas em suas especificidades para uma proposta adequada de atendimento, o que precisa ser feito não somente pela verificação dos diagnósticos clínicos, mas também de outros aspectos usualmente negligenciados no cotidiano das instituições de saúde - tais como força de ego, padrão de relacionamento interpessoal, capacidade adaptativa, entre outros (BUDMAN et al., 1994; ROSEMBERG \& ZIMET, 1995; MACKENZIE, 1996; KLEIN, 1996; SALVENDY, 1996; ZIMERMAN \& OSÓRIO, 1997; MACKENZIE, 1999c; MACKENZIE, 1999d).

Enfatizamos aqui a questão diagnóstica porque nos parece que muitas vezes existe uma pressão das instituições para que se chegue a diagnósticos únicos visando uma maior facilidade na determinação das condutas clínicas junto a um determinado paciente. Em função disto, acabam se omitindo os diagnósticos com comorbidade, apesar destes interferirem, por vezes, num determinado plano terapêutico, bem como referências a outros aspectos envolvidos na compreensão da doença. Embora as classificações nosológicas sejam fundamentais para o entendimento da mesma e, portanto, no tratamento adequado do paciente, estas não dão conta de descrever a inúmera diversidade de seus pacientes e de suas subjetividades, constituindo-se então como apenas um dos instrumentos necessários para a compreensão da problemática em questão. Concordamos com CORDIOLLI (1998) que 
“...dentro da elucidação diagnóstica merece uma atenção especial a avaliação das características de personalidade do paciente, transtorno ou traços de caráter, adaptativos ou não, pois sua presença, em especial de transtornos graves, deve ser levada em conta, pois eventualmente altera completamente o planejamento do tratamento"(p.80).

Neste sentido, ao retomarmos ao grupo objeto desse estudo vemos que estas condições iniciais, relativas à composição criteriosa do grupo, pareceram dificultadas, possivelmente por carências impostas pela organização do serviço como um todo e aos recursos dispensados à área da Saúde Mental, sendo os grupos compostos apenas com base nos diagnósticos clínicos de seus pacientes. Assim, a carência das outras formas de avaliação pode ter determinado alguns limites no processo vivido por este grupo.

A natureza deste grupo pode também ser abordada sob outras vertentes, além da caracterização de seus pacientes, considerando-se os demais aspectos pertencentes a nossa análise, quais sejam, a dinâmica das sessões do grupo e o seu manejo, e os fatores terapêuticos e não terapêuticos entendidos sob a perspectiva de seus participantes. O manejo do grupo e a dinâmica de suas sessões nos parecem aspectos intimamente relacionados, pois entendemos que o padrão de interação entre os membros do grupo sofre também a influência do modo como este é manejado. O manejo do grupo, por sua vez, encontra-se em íntima relação com a proposta terapêutica deste, com seus objetivos e com as possibilidades criadas na relação com o grupo.

Assim sendo, retomando a análise das sessões do grupo, encontramos que prevaleceu durante as mesmas as longas narrativas, a partir da exposição de problemas e situações de vida (passadas ou atuais) de um ou, no máximo, dois pacientes. Nestas situações, o grupo adotava uma postura predominantemente silente, e quando a participação verbal acontecia, esta se estruturava em forma de conselhos ou sugestões práticas sobre as situações relatadas. Por sua vez, a análise das intervenções do coordenador, revela que o grupo foi coordenado de modo a permitir a livre expressão dos pacientes durante as sessões. Predominaram intervenções que reiteravam a fala do paciente, assim sustentando as longas narrativas e a utilização do espaço do grupo para a exposição pessoal. Intervenções de orientação e informação 
foram pouco utilizadas e, ao contrário, intervenções de investigação, elucidação e confronto, apareceram com certa regularidade.

Quanto aos fatores terapêuticos e não terapêuticos do grupo, considerados sob a perspectiva de seus participantes, estes também podem ser bastante esclarecedores da natureza e do funcionamento deste grupo, sobretudo se tomados em conjunção com as outras fontes de dados. Conforme, apresentamos anteriormente, o fator terapêutico mais presente durante o grupo foi a "universalidade", seguido do fator "aprendizagem vicária"; além disso, chama a atenção a presença acentuada dos fatores não terapêuticos "distanciamento" e "desesperança". A presença destes fatores, e a quase ausência de outros ao longo das sessões do grupo ("avaliação", “orientação", por exemplo) parece guardar alguma relação tanto com o manejo do grupo como com a constituição deste grupo de terapia específico.

Entendemos que os aspectos acima apontados (dinâmica das sessões, manejo do grupo e fatores terapêuticos) se influenciam mutuamente e, portanto, visamos compreender os limites e possibilidades deste grupo através da articulação destes diferentes aspectos. Isto é, partimos do princípio que o desenvolvimento do grupo deve-se a um processo em que pacientes e terapeutas constroem conjuntamente as possibilidades e os limites dessa intervenção.

Se retomarmos a literatura sobre o tema, esta é bastante esclarecedora ao apontar alguns aspectos centrais na organização de grupos de apoio e de curta duração. Conforme referimos no capítulo introdutório, aspectos como homogeneidade do grupo, metas e objetivos terapêuticos definidos, estabelecimento de um foco (direcionamento) para o tratamento, e postura basicamente diretiva, com intervenções de apoio, orientação e avaliação por parte do coordenador, são considerados essenciais para o bom desenvolvimento do grupo (BUDMAN et al., 1994; ROSEMBERG \& ZIMET; 1995; MACKENZIE, 1996; SALVENDY, 1996; KLEIN, 1996; MACKENZIE, 1999b).

A partir destes elementos, verificamos que o manejo do grupo em questão deu-se por um modelo diferente daquele que é referido pela literatura em relação aos grupos de apoio. A ausência de um direcionamento e foco, e a presença de intervenções investigativas, elucidativas e de confronto, são sugestivas de processos terapêuticos de maior duração, onde se almeja maior compreensão do conflito 
vivenciado em seus aspectos intrapsíquicos. Então, verificando o desenvolvimento do grupo, dado por meio da análise da descrição de suas sessões e, mais especificamente dos temas abordados e do padrão de interação entre os membros, podemos traçar alguns paralelos entre o modo como os pacientes se posicionaram ao longo do processo do grupo e as formas de manejo do coordenador.

Os assuntos discutidos no grupo referiam-se, em sua grande maioria, a relatos de experiências (atuais ou passadas) e dificuldades em seus relacionamentos sócioafetivos. Porém, apesar da diversidade nos assuntos levados ao grupo, a presença recorrente de um mesmo tema pode ser evidenciada ao longo de suas sessões. Questões relativas a origem da doença ou a relações entre as situações de vida experimentadas e a presença dos sintomas, ou ainda, a dificuldades nos relacionamentos afetivos e familiares, foram marcantes durante os encontros. $\mathrm{O}$ modo de funcionamento do grupo e o padrão de interação entre seus membros também são indicativos de que os participantes pareciam conceber o grupo como um espaço de queixa e desabafo. Pareceram ter estabelecido que no grupo cada um teria o seu dia para falar, o que determinava uma postura silente do dos demais pacientes, ou no máximo, a participação através de sugestões e conselhos. Assim, criavam a possibilidade de falar de suas experiências atuais ou passadas, favorecendo no grupo uma atmosfera de respeito à participação do outro e de oferecimento de apoio e orientação (sugestões/ conselhos) entre eles.

Entendemos também que para um maior entendimento dos fatores terapêuticos e não terapêuticos do grupo, estes devem ser necessariamente articulados a uma compreensão sobre a coordenação do grupo e a dinâmica de suas sessões. Consideramos que o aspecto de sua experiência no grupo que o paciente elege ao responder o que foi importante para ele numa sessão pode ser entendido não apenas como um produto de sua participação no grupo, mas também como expressando um conjunto de expectativas que orientam sua busca pelo atendimento. Conforme, apresentamos anteriormente, o fator terapêutico mais presente durante o grupo foi a "universalidade", seguida do fator "aprendizagem vicária". Nitidamente, o predomínio destes dois fatores ao longo das sessões do grupo parece guardar alguma relação tanto com as formas de manejo como com a constituição deste grupo de terapia específico. 
Podemos afirmar que a homogeneidade dos pacientes em relação à presença de dificuldades de adaptação pode ter facilitado a convergência dos diferentes assuntos narrados no grupo a alguns temas centrais, já que em geral falavam de suas dificuldades adaptativas em relação a aspectos produtivos ou de relacionamento, e a presença de seus sintomas. A similaridade entre estes temas pode ter favorecido o aparecimento da universalidade enquanto fator terapêutico, permitindo assim que os pacientes pudessem aproximar suas experiências de vida ou se sentissem possuindo dificuldades semelhantes, apesar dos outros tantos aspectos que os diferenciavam. Assim, esta relativa homogeneidade teria permitido que os participantes percebessem a similaridade entre a natureza de seus conflitos, apesar da aparente variedade das problemáticas abordadas nas sessões.

Além disso, o padrão de interação entre os membros do grupo, caracterizado por longas narrativas sobre histórias de vida, centrais no desenvolvimento das sessões, parece ter sido fundamental para a valorização da aprendizagem vicária por estes pacientes. Se o grupo se estruturava a cada encontro, de modo que a maioria dos integrantes permanecesse silenciosa, observando o relato de um determinado membro, parece compreensível que a aprendizagem por modelo tenha sido proporcionada neste grupo. Observar a experiência alheia parece ter favorecido a percepção de alguns modelos de comportamento a serem ou não imitados em suas próprias situações de vida.

Se entendermos estes fatores terapêuticos também enquanto "expectativas" construídas / confirmadas no / pelo grupo, podemos afirmar que encontrar pessoas com vivências semelhantes ou ver-se frente a outros modelos de comportamento a partir da experiência dos demais participantes, pode ter influenciado o modo como os padrões de funcionamento do grupo foram estabelecidos. Assim, a postura do grupo de dar liberdade e criar um espaço para cada um falar de si, poderia ir ao encontro de tais expectativas.

Dentro desta perspectiva de compreensão dos dados, se retomarmos a análise das intervenções durante o grupo, podemos entendê-la sob uma nova vertente: o que esse grupo demandou de seu coordenador e como este pôde se posicionar nesse processo ao longo do desenvolvimento do grupo. Segundo os nossos dados, ao reagir à necessidade dos pacientes de falarem de si, expondo suas vivências atuais, o 
coordenador deu-lhes livre-expressão, sustentando suas falas no grupo; e ao perceber a intensa necessidade de compreensão das origens da doença e o aparecimento dos sintomas, revelados a partir dos temas abordados, estimulou-lhes à reflexão sobre suas experiências de vida (elucidando, investigando e confrontando suas falas no grupo).

Importa considerarmos ainda que os fatores não terapêuticos apareceram com freqüência relativamente acentuada na vivência dos pacientes. Algumas de suas respostas ao QIC indicavam a vivência de algumas situações que não pareciam exercer algum efeito terapêutico para o paciente (respostas da categoria “distanciamento") ou que, ao contrário, pareciam evidenciar momentos de intensa ansiedade, angústia, desesperança e dificuldade de elaboração (respostas da categoria "desesperança"). Em parte, estes dados falam por si mesmos. Algumas situações vividas no grupo não pareceram ser toleradas pelos pacientes. Porém, o que poderia ter provocado estas respostas emocionais negativas?

Neste sentido, vale a pena apontar que grande parte destas respostas que traziam elementos classificados como não terapêuticos, foram dadas por três pacientes (Ana Maria, Marta e Marli). Disto deriva a hipótese de que suas características individuais possam ter influenciado no aparecimento de vivências negativas no grupo. Embora todos os pacientes apresentassem comprometimento em suas capacidades de adaptação, o nível deste comprometimento não pôde ser inferido no momento da constituição do grupo, como já apontamos anteriormente, dado que seus critérios de seleção não permitiam uma compreensão mais global das condições de cada paciente, sinalizando um limite do funcionamento do serviço que pode gerar para alguns pacientes experiências não terapêuticas.

Outro fator a ser considerado nesta reflexão sobre os fatores não terapêuticos, é o próprio padrão de interação entre os participantes. Apesar do grupo adotar como modo de funcionamento os relatos únicos dos pacientes, que se alternavam durante as sessões, esta situação pode também ter sido responsável pelo aumento do nível de angústia em alguns encontros, dependendo do que estes relatos mobilizavam.

De qualquer modo, a literatura sobre os fatores terapêuticos aponta para a influência de características individuais na valorização, pelos pacientes, dos 
diferentes fatores (KIVLIGHAN \& GOLDFINE, 1991; VINOGRADOV \& YALOM, 1992; SCHOPLER E GALINSKY, 1993).

As hipóteses acima apontadas vão ao encontro da argumentação anterior de que a carência de outras formas de avaliação dos pacientes no momento de seu encaminhamento para o grupo pode ter implicado em alguns limites para o desenvolvimento do mesmo e de alguns pacientes em particular.

Outros fatores terapêuticos também foram evidenciados ao longo do grupo, porém com pouca freqüência se comparados aos demais fatores apresentados. Dentre eles, parece-nos dissonante que a "auto-revelação" e a "catarse" tenham sido fatores terapêuticos pouco evidenciados, sobretudo em vista do padrão de funcionamento do grupo - considerado tanto em função de seu manejo como do padrão de interação entre os membros. Estes são fatores tidos como típicos em grupos de apoio, conforme nos sugere a literatura sobre o tema. Isto nos faz pensar que embora os pacientes tenham falado de suas experiências emocionais e liberado sentimentos durante seus relatos, não pareceram dar ênfase a este aspecto de sua experiência no grupo, comparativamente ao aparecimento de outros fatores.

Este dado pode guardar relações também com o modo como os pacientes se apropriam de alguns conhecimentos sobre como se organiza a situação terapêutica. Ou seja, parece haver uma concepção de que o tratamento está baseado no "falar de si e de sentimentos", o que faz com que dividam o tempo do grupo para que cada um tenha um espaço para exposição de suas dificuldades (um dia para cada um). Ao coordenador, fica o papel da escuta e de interpretação, o que repete o modelo da psicoterapia individual.

Também outros fatores apontados como usuais em terapias de apoio, como aceitação, instilação de esperança e orientação, não tiveram grandes frequiências de aparecimento neste grupo. Podemos hipotetizar que estes fatores não estiveram presentes nas respostas dos pacientes por terem sido pouco favorecidos - a postura menos diretiva do coordenador pareceu centrar-se em intervenções voltadas para o aparecimento de outros fatores terapêuticos, mais relacionados àaquisição de alguma compreensão interna por parte dos pacientes. Porém, o fator terapêutico que seria correspondente a esta expectativa (auto-entendimento) não apareceu em nossa 
classificação de suas respostas, sugerindo ser esta uma expectativa pouco realista para o contexto do grupo de curta duração.

Este fato também encontra respaldo na literatura sobre o tema, onde muitos autores apontam como objetivos dos grupos de curta duração o oferecimento de apoio, o restabelecimento do equilíbrio emocional e a remissão de sintomas, em oposição àreestruturação de personalidade advinda de um maior conhecimento sobre aspectos intrapsíquicos (BUDMAN et al.., 1994; ROSEMBERG \& ZIMET, 1995; KLEIN, 1996).

Portanto, em termos gerais, entendemos que a compreensão dos fatores terapêuticos presentes neste grupo deve considerar as dimensões já apontadas por VINOGRADOV \& YALOM (1992) como variáveis modificadoras dos fatores terapêuticos, quais sejam, as características individuais e o tipo de grupo. Porém, mais do que isto, esta discussão deve estimular uma reflexão sobre o que poderia ser feito para se minimizar a influência destas características individuais no momento da composição do grupo - e para isto a literatura é bastante fértil em termos de quais aspectos devem ser levados em consideração na composição de grupos de apoio ou psicoterápicos em geral (VINOGRADOV \& YALOM, 1992; BUDMAN et al., 1994; SALVENDY, 1996; KLEIN, 1996; MACKENZIE, 1996; ZIMERMAN \& OSÓRIO, 1997; MACKENZIE, 1999c).

Assim, com base nas pontuações acima, podemos tecer algumas considerações gerais sobre a natureza deste grupo estudado, em seus limites e possibilidades, considerando-se o contexto mais amplo em que esta prática se desenvolve. 


\section{8- CONSIDERAÇÕES FINAIS}

Pensando nas possibilidades terapêuticas deste grupo podemos apontar que este se caracterizou por um processo bastante peculiar, que o distingue tanto dos grupos de apoio como dos grupos de longa duração, segundo definidos pela literatura. Sua natureza pôde ser definida pelos limites de seu contexto e das condições que determinaram sua existência, considerando que não podemos pensar esta prática deslocada do contexto em que se desenvolveu.

Conforme apontamos anteriormente, a prática de atendimento em grupo desenvolveu-se em resposta a mudanças nas concepções em Saúde Mental e à reforma psiquiátrica. $\mathrm{O}$ surgimento dos ambulatórios e outros sistemas alternativos aos sistemas hospitalares criaram a necessidade de outras modalidades de atendimento, sendo que as práticas grupais acabaram assumindo importante papel no desenvolvimento destes serviços.

Apesar dos avanços nas propostas de atendimento terem se dado em resposta também a uma maior conscientização quanto aos direitos civis dos doentes mentais, legitimando formas de atendimento mais humanitárias e com efetivo valor terapêutico, o maior emprego das práticas grupais parece se dar também com base em outros incentivos. Concordamos com BEZERRA JUNIOR (1992) que "quando se abordam as terapias de grupo, parece que por vezes já não se vêem outras razões para elas que não a economia de tempo dos profissionais, as exigências de produtividade dos ambulatórios, e a necessidade de diminuir as filas de espera” (p.162).

Assim, não se elaboram propostas de grupo de modo a potencializar suas contribuições ao campo da Saúde Mental, apesar da literatura apresentar dados que comprovam que sua eficácia terapêutica é muitas vezes ligeiramente maior que a das próprias terapias individuais (BUDMAN et al., 1994; MACKENZIE, 1996; MACKENZIE, 1999a; MACKENZIE, 1999b). Ao contrário, busca-se implementar este modelo de atendimento submetendo-o àrealidade dos serviços, carentes de recursos financeiros e de formação profissional adequada para incorporar tais propostas alternativas æ̀ formas de atendimento tradicionais.

Segundo BEZERRA JUNIOR (1992), o fato de se justificar o emprego das psicoterapias breves apenas por argumentos quanto às vantagens de custo destas práticas e sobre o aumento do número de pacientes que buscam tratamento, "pode 
conduzir a uma posição eticamente insustentável, qual seja, a de subordinar estratégias terapêuticas a injunções burocráticas financeiras" (p.160). Assim, aponta que a duração de um tratamento deve variar em função de alguns aspectos, tais como características pessoais, quadro clínico dos pacientes, gravidade da doença, entre outros. Outro aspecto apontado por este autor, refere-se àusual afirmação de que as psicoterapias de tempo limitado têm alcance terapêutico restrito, promovendo apenas alívio sintomático e rearranjo superficial do funcionamento psíquico do paciente. À psicanálise, ficaria atribuída a cura definitiva. Cria-se, assim, uma suposta hierarquia entre as psicoterapias e uma falsa compreensão das possibilidades destas formas de atendimento. Segundo afirma,

"é necessário retornar a interrogação quanto à validade desta hierarquia (é possível eliminar sintomas sem alterar o funcionamento patológico que lhe deu origem?) para que se possa colocar a discussão sobre as terapias breves em outro plano que não o habitual". Trata-se, portanto, não de se encontrar uma fórmula econômica viável de "equacionar demandas crescentes e recursos limitados, mas de investigar as possibilidades de modelos de atenção que melhor pudessem responder à particularidades e idiossincrasias da clientela dos ambulatórios" (BEZERRA JUNIOR, 1992, p.162).

Porém, um dos aspectos centrais é que haja condições nos serviços de atendimento em Saúde Mental para uma adequada avaliação e encaminhamento dos pacientes a um tipo de tratamento indicado, seja ele medicamentoso, seja ele psicoterápico, ou ambos. Este é um dos aspectos referidos no item III da Carta dos Direitos dos Usuários e Familiares de Serviço em Saúde Mental, redigida a partir do III Encontro Nacional de Entidades de Usuários e Familiares da Luta Antimanicomial, realizado em Santos, e dezembro de 1992:

“...todo serviço de triagem em Saúde Mental deve incluir uma avaliação psiquiátrica, psicológica, médico-clínica e social que garanta uma visão ampla e integrada do usuário e que respeite a sua fragilidade e dignidade como pessoa humana" (CONSELHO REGIONAL DE PSICOLOGIA, $6^{\mathrm{a}}$ região, 1997, p.157).

A seleção para atendimento em grupo não foge a esta regra, já que estudos demonstram que as psicoterapias de grupo funcionam muito bem, apresentando resultados comparáveis a outras modalidades de atendimento psicoterápico, desde 
que se disponha de uma seleção criteriosa de seus integrantes (VINOGRADOV \& YALOM, 1992; BUDMAN et al, 1994; SALVENDY, 1996; KLEIN, 1996; MACKENZIE, 1996; ZIMERMAN \& OSÓRIO, 1997; MACKENZIE, 1999c; MACKENZIE, 1999d).

Especificamente em relação à psicoterapia de apoio, em grupos de tempo limitado, pesquisas demonstram a importância de que haja empenho por parte dos profissionais na determinação das metas terapêuticas e de focos para o tratamento, o que deve ser necessariamente trabalhado em conjunto com o paciente antes do início do grupo propriamente dito. Assim, instrumentos adequados são necessários para avaliar não só diagnósticos clínicos, como também condições individuais para o tratamento, motivações e padrões de relacionamento interpessoal (MACKENZIE, 1996). Estes aspectos favorecem a composição de um grupo homogêneo, com expectativas realistas quanto aos objetivos a serem alcançados a partir do tratamento no grupo - o que é fundamental no estabelecimento da coesão grupal e da aliança terapêutica, características centrais para o bom desenvolvimento do processo do grupo (VINOGRADOV \& YALOM, 1992; BUDMAN et al., 1994; MACKENZIE, 1996; KLEIN, 1996; MACKENZIE, 1999a)

Se os serviços não se organizarem de modo a favorecerem a reflexão sobre estas questões, visando a proposta de atendimentos de qualidade e com finalidades realmente terapêuticas, corre-se o risco de que os serviços ambulatoriais apenas encubram o modelo manicomial, estabelecendo atendimentos tão cronificadores quanto as formas anteriores de atendimento ao portador de doença mental (VASCONCELOS, 1990).

Um dos aspectos sugestivos desta possibilidade é que, muitas vezes, os atendimentos de curta duração executam-se como de longa duração. Assim, terminado um grupo de tempo limitado, o paciente não obtém alta, e é inserido num outro grupo, dando início a um novo processo de curta duração. Assim, as pressões sócio-econômicas parecem intervir na constituição e organização dos grupos nessas instituições, sendo que a necessidade de atender em psicoterapia maior número de pacientes, parece determinar a adoção dos atendimentos de curta duração, sem que haja, em paralelo, uma modificação dos objetivos e da forma destas intervenções. Assim, a impressão que se tem é que se reduz o tempo do grupo, mas não se alteram 
os seus objetivos, que continuam a funcionar como grupos de longa duração em moldes tradicionais (SALVENDY, 1996; BUDMAN, et al., 1994). Em nosso estudo, este é um aspecto que pode ser percebido a partir dos registros de prontuário. A maioria dos pacientes já havia passado por atendimentos psiquiátricos anteriores, e cerca da metade dos pacientes participado de experiências de psicoterapia de grupo.

Outro aspecto a ser considerado, é que em conseqüência da diminuição das internações e da proposta de modelos assistenciais alternativos aos hospitais, a clientela dos ambulatórios também mudou consideravelmente. Hoje recebem atendimentos em ambulatórios também pacientes com grave comprometimento, o que faz com que haja nestes serviços a necessidade de condições mínimas para o exercício de uma assistência de qualidade. Concordamos com BANDEIRA \& SOARES (1996) que a implementação dos projetos de desinstitucionalização "implica em uma serie de cuidados, se quisermos garantir seu bom funcionamento, entre outros, a preparação adequada dos recursos humanos" (p.160). Estes autores apontam, ainda, que após a implementação de uma determinada proposta, há a necessidade de um monitoramento contínuo do programa, como forma de poder se trabalhar as dificuldades cotidianas destas instituições. Assim,

"é necessária uma avaliação contínua da clientela ao qual o programa se aplica, da aplicação e da formação dos profissionais que fornecem o serviço, da coordenação e funcionamento dos diversos setores entre si, dos efeitos do programa em termos de eficácia e de sua repercussão nos diversos setores da sociedade" (idem, p.160).

Considerando-se este contexto, parece evidente alguns dos limites que impediram a potencialização de aspectos terapêuticos deste grupo, tais como: a carência de critérios definidos para a composição do grupo; metas terapêuticas possíveis de serem realizadas em uma estrutura de tempo limitado; presença de um foco para o tratamento, entre outros.

Frente à realidade com que nos deparamos nos sistemas de saúde, pensamos ser necessário repensar as possibilidades de sobrevivência das práticas grupais neste contexto de carências, para que os encontros entre pacientes e profissionais possam ser potencializados em suas metas terapêuticas, assim desenvolvendo-se de forma a 
tentar de fato reduzir o sofrimento psíquico da clientela que se dispõe a atender a partir de suas intervenções. Concordamos com CESARINO (1989) que

“é possível oferecer um serviço de bom padrão a partir do poder público. Para isso é necessário que dêem determinadas condições, raras na história da saúde mental entre nós. Decisão política de melhorar este trabalho, que se traduz em apoio efetivo, verbas, prestígio, etc e presença de pessoal técnico capacitado, e ainda não desmotivado e descerebrado pela burocracia e autoritarismo" (p.19).

Portanto, parece-nos que ao oferecer condições e recursos para que os profissionais desenvolvam suas habilidades, e para que haja condições mínimas de funcionamento nos serviços de Saúde Mental, pode haver maior possibilidade de tratamento da população atendida neste campo.

Porém, apesar de todas estas adversidades entendemos que o grupo em questão pôde, em seu desenvolvimento, criar algumas possibilidades terapêuticas a partir de uma sintonia entre a demanda do grupo e a disponibilidade do coordenador de oferecer um espaço aberto a esta diversidade. Assim, embora não possamos defino-lo enquanto grupo de apoio, ou de orientação psicodinâmica, a partir de definições da literatura, sua natureza define-se a partir de uma prática construída no cotidiano desta e de outras instituições. Driblando as adversidades de um sistema de saúde ainda incipiente, profissionais e doentes parecem ainda investir nas possibilidades de encontro, assim buscando meios para a criação de novas realidades. 


\section{9- ANEXOS}




\section{ANEXO 1}

CONSENTIMENTO INFORMADO

$\mathrm{Eu}$, aceito ser participante de um estudo que estará sendo realizado no grupo de psicoterapia em que estarei sendo atendido no (nome do serviço).

Minha aceitação significa que concordo em conversar com o pesquisador sobre o que foi importante para mim no grupo, após cada sessão, e que autorizo que nossa conversa seja gravada em fita K-7.

Declaro também:

1) que estou aceitando voluntariamente a participação nesse estudo, não tendo sofrido nenhuma forma de pressão para isso;

2) que posso deixar de participar do estudo, a qualquer momento, se eu desejar, sem que para isso eu tenha que interromper meu atendimento no grupo ou no (nome do serviço); e

3) que fui assegurado que minhas informações serão utilizadas somente para o estudo do grupo e de forma a não me identificar.

Ribeirão Preto, de de 
Nome do(a) Paciente:

Data:

Avalie o nível de ajustamento psicossocial do paciente em cada um dos aspectos abaixo referidos, considerando o MOMENTO DE ENCAMINHAMENTO PARA O TRATAMENTO EM GRUPO, e assinale em cada um deles a alternativa que melhor descreva sua avaliação.

\section{ASPECTO AFETIVO-RELACIONAL}

No momento atual, o paciente apresenta muitas dificuldades e conflitos frente aos relacionamentos afetivos (sociais e/ou familiares).

No momento atual, o paciente apresenta algumas dificuldades e conflitos frente aos relacionamentos afetivos (sociais e/ou familiares).

No momento atual, o paciente não apresenta dificuldades e conflitos frente aos relacionamentos afetivos (sociais e/ou familiares).

\section{ASPECTO PRODUTIVO}

No momento atual, o paciente não consegue exercer atividades regulares e produtivas (trabalho, estudo ou outra atividade principal do paciente).

No momento atual, o paciente exerce com alguma dificuldade atividades regulares e produtivas (trabalho, estudo ou outra atividade principal do paciente).

No momento atual, o paciente exerce sem dificuldade atividades regulares e produtivas (trabalho, estudo ou outra atividade principal do paciente).

\section{ASPECTO SÓCIO-CULTURAL}

No momento atual, o paciente apresenta muita dificuldade em lidar com os costumes e valores do ambiente em que vive.

No momento atual, o paciente apresenta alguma dificuldade em lidar com os costumes e valores do ambiente em que vive.

No momento atual, o paciente não apresenta dificuldade em lidar com os costumes e valores do ambiente em que vive.

\section{CAPACIDADE ADAPTATIVA}

No momento atual, as queixas ou o quadro clínico apresentado pelo paciente limitam muito sua capacidade adaptativa.

No momento atual, as queixas ou o quadro clínico apresentado pelo paciente limitam parcialmente sua capacidade adaptativa.

No momento atual, as queixas ou o quadro clínico apresentado pelo paciente não interferem em sua capacidade adaptativa.

\section{AVALIAÇÃO GLOBAL}

No momento atual, considerando as condições gerais do paciente, avalio que seu ajustamento psicossocial encontra-se prejudicado.

No momento atual, considerando as condições gerais do paciente, avalio que seu ajustamento psicossocial encontra-se razoável.

No momento atual, considerando as condições gerais do paciente, avalio que seu ajustamento psicossocial encontra-se bom. 
Continuação...

Avalie o nível de ajustamento psicossocial do paciente em cada um dos aspectos abaixo referidos, considerando o MOMENTO DE TÉRMINO DO TRATAMENTO EM GRUPO, e assinale em cada um deles a alternativa que melhor descreva sua avaliação.

\section{ASPECTO AFETIVO-RELACIONAL}

No momento atual, o paciente apresenta muitas dificuldades e conflitos frente aos relacionamentos afetivos (sociais e/ou familiares).

No momento atual, o paciente apresenta algumas dificuldades $e$ conflitos frente aos relacionamentos afetivos (sociais e/ou familiares).

No momento atual, o paciente não apresenta dificuldades $\boldsymbol{e}$ conflitos frente aos relacionamentos afetivos (sociais e/ou familiares).

\section{ASPECTO PRODUTIVO}

No momento atual, o paciente não consegue exercer atividades regulares e produtivas (trabalho, estudo ou outra atividade principal do paciente).

No momento atual, o paciente exerce com alguma dificuldade atividades regulares e produtivas (trabalho, estudo ou outra atividade principal do paciente).

No momento atual, o paciente exerce sem dificuldade atividades regulares e produtivas (trabalho, estudo ou outra atividade principal do paciente).

\section{ASPECTO SÓCIO-CULTURAL}

No momento atual, o paciente apresenta muita dificuldade em lidar com os costumes e valores do ambiente em que vive.

No momento atual, o paciente apresenta alguma dificuldade em lidar com os costumes e valores do ambiente em que vive.

No momento atual, o paciente não apresenta dificuldade em lidar com os costumes e valores do ambiente em que vive.

\section{CAPACIDADE ADAPTATIVA}

No momento atual, as queixas ou o quadro clínico apresentado pelo paciente limitam muito sua capacidade adaptativa.

No momento atual, as queixas ou o quadro clínico apresentado pelo paciente limitam parcialmente sua capacidade adaptativa.

No momento atual, as queixas ou o quadro clínico apresentado pelo paciente não interferem em sua capacidade adaptativa.

\section{AVALIAÇÃO GLOBAL}

No momento atual, considerando as condições gerais do paciente, comparando ao momento de encaminhamento ao tratamento em grupo, avalio que seu ajustamento psicossocial piorou.

No momento atual, considerando as condições gerais do paciente, comparando ao momento de encaminhamento ao tratamento em grupo, avalio que seu ajustamento psicossocial manteve-se sem alteração.

No momento atual, considerando as condições gerais do paciente, comparando ao momento de encaminhamento ao tratamento em grupo, avalio que seu ajustamento psicossocial melhorou. 
ANEXO 3

Intervenções do coordenador que foram consideradas no cálculo da fidedignidade do sistema de categorias descritivo do manejo do grupo.

Legenda:
$\mathrm{p}$ : paciente
g: grupo
A: acordo
D: desacordo
R: reiteração;
I: investigação;
E: elucidação;
C: confrontação;
E: enquadre;
A: avaliação;
O: orientação;
FI: fala interrompida

\begin{tabular}{|c|c|c|c|c|c|}
\hline \multirow[t]{2}{*}{ Sessão } & \multirow[t]{2}{*}{ Intervenção* } & \multicolumn{2}{|c|}{ Avaliadores } & \multirow{2}{*}{$\begin{array}{c}\text { Classificação } \\
\text { final }\end{array}$} & \multirow{2}{*}{$\begin{array}{r}\text { Acordo/ } \\
\text { desacordo }\end{array}$} \\
\hline & & 1 & 2 & & \\
\hline \multirow{6}{*}{$\begin{array}{c}1^{\text {a }} \quad \text { sessão } \\
\mathrm{N}=71\end{array}$} & 10 & $\mathrm{Rp}$ & $\mathrm{Rp}$ & $\mathrm{Rp}$ & $\mathrm{A}$ \\
\hline & 19 & $\mathrm{Ep}$ & Ep & Ep & $\mathrm{A}$ \\
\hline & 30 & $\mathrm{Rp}$ & $\mathrm{Rp}$ & $\mathrm{Rp}$ & A \\
\hline & 41 & $\mathrm{Rp}$ & $\mathrm{Rp}$ & $\mathrm{Rp}$ & $\mathrm{A}$ \\
\hline & 51 & $\mathrm{Rp}$ & $\mathrm{Rp}$ & $\mathrm{Rp}$ & $\mathrm{A}$ \\
\hline & 63 & $\mathrm{Cp}$ & $\mathrm{Cp}$ & $\mathrm{Cp}$ & $\mathrm{A}$ \\
\hline \multirow{14}{*}{$\begin{array}{c}2^{\mathrm{a}} \quad \text { sessão } \\
\mathrm{N}=106\end{array}$} & 4 & $\mathrm{Ig}$ & $\mathrm{Ig}$ & $\mathrm{Ig}$ & $\mathrm{A}$ \\
\hline & 13 & $\mathrm{Eg}$ & $\mathrm{Eg}$ & $\mathrm{Eg}$ & $\mathrm{A}$ \\
\hline & 14 & Ip & Ip & Ip & $\mathrm{A}$ \\
\hline & 25 & $\mathrm{Eg}$ & $\mathrm{Eg}$ & $\mathrm{Eg}$ & $\mathrm{A}$ \\
\hline & 35 & $\mathrm{Rp}$ & $R p$ & $\mathrm{Rp}$ & $\mathrm{A}$ \\
\hline & 45 & $\mathrm{Rp}$ & $\mathrm{Rp}$ & $\mathrm{Rp}$ & $\mathrm{A}$ \\
\hline & 55 & $\mathrm{Ip}$ & Ip & Ip & A \\
\hline & 65 & Elp & Elp & Elp & $\mathrm{A}$ \\
\hline & 75 & $\mathrm{Cp}$ & $\mathrm{Cp}$ & $\mathrm{Cp}$ & $\mathrm{A}$ \\
\hline & 76 & Ip & Ip & $\mathrm{Ip}$ & $\mathrm{A}$ \\
\hline & 87 & $\mathrm{Rg}$ & $\mathrm{Rg}$ & $\mathrm{Rg}$ & $\mathrm{A}$ \\
\hline & 96 & Op & Op & Op & A \\
\hline & 103 & $\mathrm{Eg}$ & $\mathrm{Eg}$ & $\mathrm{Eg}$ & $\mathrm{A}$ \\
\hline & 104 & Elg & Elg & Elg & $\mathrm{A}$ \\
\hline \multirow{13}{*}{$\begin{array}{c}3^{\mathrm{a}} \quad \text { essão } \\
\mathrm{N}=128\end{array}$} & 7 & $\mathrm{Eg}$ & $\mathrm{Eg}$ & $\mathrm{Eg}$ & $\mathrm{A}$ \\
\hline & 18 & Ip & Ip & Ip & A \\
\hline & 27 & Elp & Elp & Elp & $\mathrm{A}$ \\
\hline & 36 & $\mathrm{Cp}$ & $\mathrm{Cp}$ & $\mathrm{Cp}$ & $\mathrm{A}$ \\
\hline & 45 & $\mathrm{Rp}$ & $\mathrm{Rp}$ & $\mathrm{Rp}$ & $\mathrm{A}$ \\
\hline & 55 & $\mathrm{Rp}$ & Ip & Ip & $\mathrm{D}$ \\
\hline & 65 & Elg & Elg & Elg & $\mathrm{A}$ \\
\hline & 75 & Elg & Elg & Elg & $\mathrm{A}$ \\
\hline & 87 & $\mathrm{Eg}$ & $\mathrm{Ig}$ & $\mathrm{Ig}$ & $\mathrm{D}$ \\
\hline & 88 & $\mathrm{Eg}$ & $\mathrm{Eg}$ & $\mathrm{Eg}$ & $\mathrm{A}$ \\
\hline & 98 & $\mathrm{Rp}$ & $\mathrm{Rp}$ & $\mathrm{Rp}$ & $\bar{A}$ \\
\hline & 108 & $\mathrm{Rp}$ & $\mathrm{Rp}$ & $\mathrm{Rp}$ & $\mathrm{A}$ \\
\hline & 118 & Elg & Elg & Elg & A \\
\hline
\end{tabular}

* Embora o critério utilizado tenha sido o de selecionar uma em cada dez intervenções, consideradas na sequiência total das sessões, os números das intervenções consideradas não segue rigorosamente o intervalo de dez, uma vez que algumas intervenções foram divididas em duas e outras reagrupadas em função da análise realizada. 


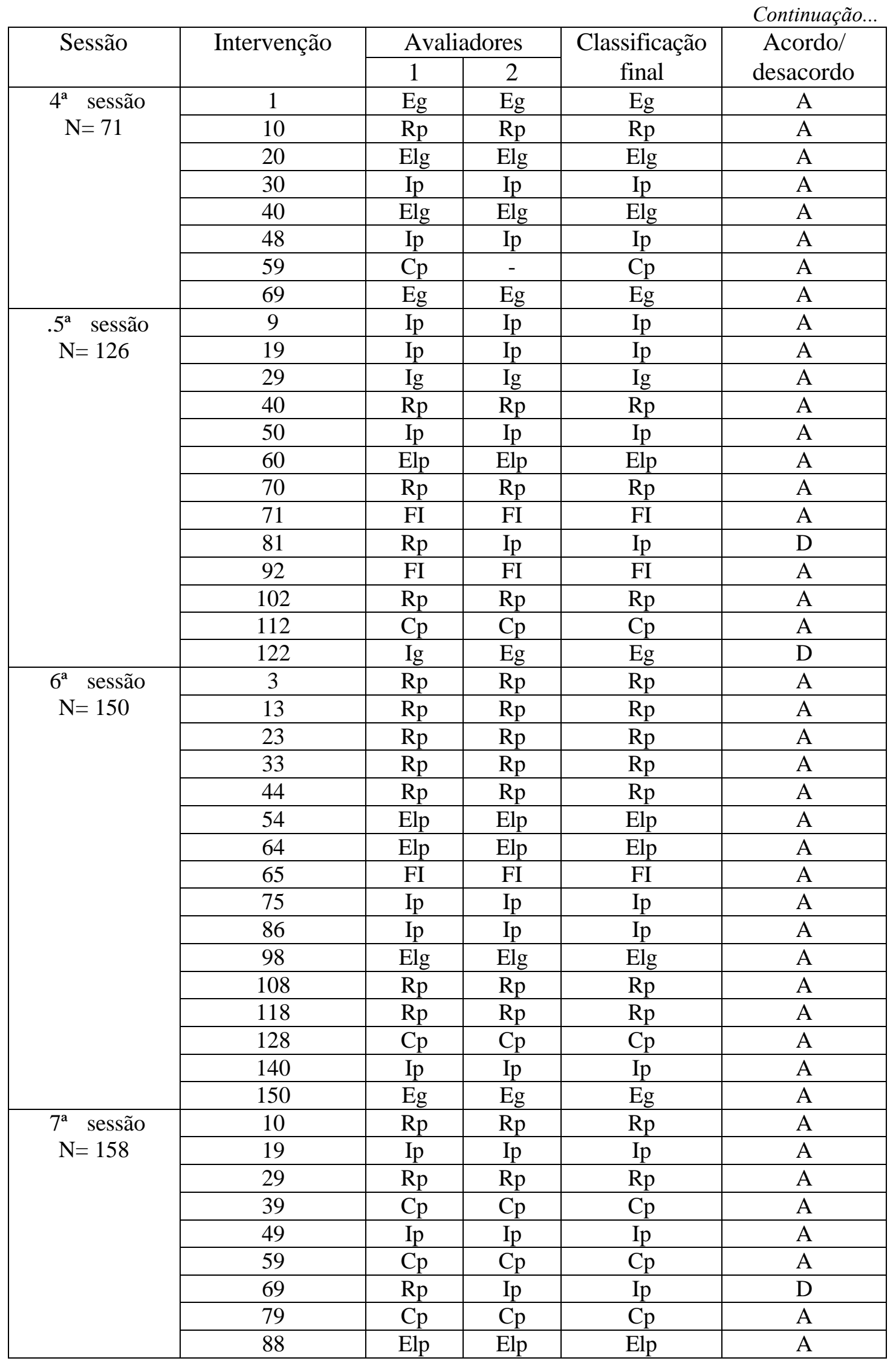




\begin{tabular}{|c|c|c|c|c|c|}
\hline \multirow{3}{*}{ Sessão } & \multirow{3}{*}{ Intervenção } & & & \multicolumn{2}{|r|}{ Continuação } \\
\hline & & \multicolumn{2}{|c|}{ Avaliadores } & \multirow{2}{*}{$\begin{array}{c}\text { Classificação } \\
\text { final }\end{array}$} & \multirow{2}{*}{$\begin{array}{c}\text { Acordo/ } \\
\text { desacordo }\end{array}$} \\
\hline & & 1 & 2 & & \\
\hline & 97 & $\mathrm{Cp}$ & $\mathrm{Cp}$ & $\mathrm{Cp}$ & $\mathrm{A}$ \\
\hline & 106 & FI & FI & FI & $\overline{\mathrm{A}}$ \\
\hline & 116 & $\mathrm{Rp}$ & Ip & Ip & $\mathrm{D}$ \\
\hline & 126 & $\mathrm{Rp}$ & $\mathrm{Rp}$ & $\mathrm{Rp}$ & $\mathrm{A}$ \\
\hline & 135 & $\mathrm{Cp}$ & $\mathrm{Cp}$ & $\mathrm{Cp}$ & $\mathrm{A}$ \\
\hline & 145 & Elg & Elg & Elg & $\mathrm{A}$ \\
\hline & 154 & $\mathrm{Eg}$ & $\mathrm{Eg}$ & $\mathrm{Eg}$ & $\mathrm{A}$ \\
\hline \multirow{12}{*}{$\begin{array}{c}8^{\mathrm{a}} \quad \text { sessão } \\
\mathrm{N}=114\end{array}$} & 2 & $\mathrm{Eg}$ & $\mathrm{Eg}$ & $\mathrm{Eg}$ & $\mathrm{A}$ \\
\hline & 12 & $\mathrm{Rp}$ & $\mathrm{Rp}$ & $\mathrm{Rp}$ & $\mathrm{A}$ \\
\hline & 22 & $\mathrm{Rp}$ & $\mathrm{Rp}$ & $\mathrm{Rp}$ & $\mathrm{A}$ \\
\hline & 32 & $\mathrm{Cp}$ & $\mathrm{Cp}$ & $\mathrm{Cp}$ & $\mathrm{A}$ \\
\hline & 42 & $\mathrm{Rp}$ & $\mathrm{Rp}$ & $\mathrm{Rp}$ & $\mathrm{A}$ \\
\hline & 52 & $\mathrm{Rp}$ & $\mathrm{Rp}$ & $\mathrm{Rp}$ & $\mathrm{A}$ \\
\hline & 62 & $\mathrm{Cp}$ & $\mathrm{Rp}$ & $\mathrm{Rp}$ & $\mathrm{D}$ \\
\hline & 72 & Ip & $\mathrm{Cp}$ & $\mathrm{Cp}$ & $\mathrm{D}$ \\
\hline & 82 & $\mathrm{Cp}$ & $\mathrm{Cp}$ & $\mathrm{Cp}$ & $\mathrm{A}$ \\
\hline & 92 & $\mathrm{Cp}$ & Ip & Ip & $\mathrm{D}$ \\
\hline & 100 & $\mathrm{Rp}$ & $\mathrm{Rp}$ & $\mathrm{Rp}$ & $\mathrm{A}$ \\
\hline & 111 & FI & FI & FI & $\mathrm{A}$ \\
\hline \multirow{9}{*}{$\begin{array}{c}9^{a} \quad \text { sessão } \\
N=93\end{array}$} & 8 & $\mathrm{Rp}$ & $\mathrm{Rp}$ & $\mathrm{Rp}$ & $\mathrm{A}$ \\
\hline & 18 & Ap & Ap & Ap & $\mathrm{A}$ \\
\hline & 29 & $\mathrm{Cp}$ & $\mathrm{Cp}$ & $\mathrm{Cp}$ & $\mathrm{A}$ \\
\hline & 38 & $\mathrm{Rp}$ & $\mathrm{Rp}$ & $\mathrm{Rp}$ & $\mathrm{A}$ \\
\hline & 48 & Elg & Elg & Elg & $\mathrm{A}$ \\
\hline & 59 & Ip & Ip & $\mathrm{Ip}$ & $\mathrm{A}$ \\
\hline & 69 & $\mathrm{Cp}$ & $\mathrm{Cp}$ & $\mathrm{Cp}$ & $\mathrm{A}$ \\
\hline & 79 & $\mathrm{Rp}$ & $\mathrm{Rp}$ & $\mathrm{Rp}$ & $\mathrm{A}$ \\
\hline & 90 & $\mathrm{Rp}$ & $\mathrm{Rp}$ & $\mathrm{Rp}$ & $\mathrm{A}$ \\
\hline \multirow{15}{*}{$\begin{array}{c}10^{\mathrm{a}} \text { sessão } \\
\mathrm{N}=147\end{array}$} & 7 & $\mathrm{Eg}$ & $\mathrm{Eg}$ & $\mathrm{Eg}$ & $\mathrm{A}$ \\
\hline & 17 & $\mathrm{Rp}$ & $\mathrm{Rp}$ & $\mathrm{Rp}$ & $\mathrm{A}$ \\
\hline & 27 & $\mathrm{Rp}$ & $\mathrm{Rp}$ & $\mathrm{Rp}$ & $\mathrm{A}$ \\
\hline & 37 & $\mathrm{Rp}$ & $\mathrm{Rp}$ & $\mathrm{Rp}$ & $\mathrm{A}$ \\
\hline & 47 & $\mathrm{Cp}$ & $\mathrm{Cp}$ & $\mathrm{Cp}$ & $\mathrm{A}$ \\
\hline & 57 & Elp & $\mathrm{Cp}$ & $\mathrm{Cp}$ & $\mathrm{D}$ \\
\hline & 67 & $\mathrm{Rp}$ & $\mathrm{Rp}$ & $\mathrm{Rp}$ & $\mathrm{A}$ \\
\hline & 77 & Elg & Elg & Elg & $\mathrm{A}$ \\
\hline & 87 & $\mathrm{Cp}$ & $\mathrm{Cp}$ & $\mathrm{Cp}$ & $\mathrm{A}$ \\
\hline & 97 & $\mathrm{Cg}$ & $\mathrm{Cg}$ & $\mathrm{Cg}$ & A \\
\hline & 98 & FI & Ip & Ip & $\mathrm{D}$ \\
\hline & 108 & $\mathrm{Ap}$ & Ap & Ap & $\mathrm{A}$ \\
\hline & 118 & $\mathrm{Cp}$ & $\mathrm{Cp}$ & $\mathrm{Cp}$ & $\mathrm{A}$ \\
\hline & 127 & $\mathrm{Rp}$ & $\mathrm{Rp}$ & $\mathrm{Rp}$ & A \\
\hline & 137 & Ip & Ip & Ip & $\mathrm{A}$ \\
\hline \multirow{3}{*}{$\begin{array}{c}11^{\mathrm{a}} \text { sessão } \\
\mathrm{N}=136\end{array}$} & 2 & $\mathrm{Ep}$ & $\mathrm{Ep}$ & Ep & $\mathrm{A}$ \\
\hline & 12 & Elp & Elp & Elp & $\mathrm{A}$ \\
\hline & 22 & $\mathrm{Cp}$ & $\mathrm{Cp}$ & $\mathrm{Cp}$ & $\mathrm{A}$ \\
\hline
\end{tabular}




\begin{tabular}{|c|c|c|c|c|c|}
\hline \multirow{3}{*}{ Sessão } & \multirow{3}{*}{ Intervenção } & & & \multicolumn{2}{|c|}{ Continuação. } \\
\hline & & \multicolumn{2}{|c|}{ Avaliadores } & \multirow{2}{*}{$\begin{array}{c}\text { Classificação } \\
\text { final }\end{array}$} & \multirow{2}{*}{$\begin{array}{c}\text { Acordo/ } \\
\text { desacordo }\end{array}$} \\
\hline & & 1 & 2 & & \\
\hline & 32 & $\mathrm{Ig}$ & $\mathrm{Ig}$ & $\mathrm{Ig}$ & A \\
\hline & 42 & $\mathrm{Rp}$ & $\mathrm{Rp}$ & $\mathrm{Rp}$ & $\mathrm{A}$ \\
\hline & 52 & $\mathrm{Rp}$ & $\mathrm{Rp}$ & $\mathrm{Rp}$ & $\mathrm{A}$ \\
\hline & 62 & $\mathrm{Rp}$ & $\mathrm{Rp}$ & $\mathrm{Rp}$ & $\mathrm{A}$ \\
\hline & 72 & Elp & Elp & Elp & $\mathrm{A}$ \\
\hline & 82 & $\mathrm{Ip}$ & $\mathrm{Ip}$ & $\mathrm{Ip}$ & $\mathrm{A}$ \\
\hline & 92 & Ip & Ip & Ip & $\mathrm{A}$ \\
\hline & 102 & $\mathrm{Rp}$ & $\mathrm{Rp}$ & $\mathrm{Rp}$ & $\mathrm{A}$ \\
\hline & 112 & $\mathrm{Rp}$ & $\mathrm{Rp}$ & $\mathrm{Rp}$ & $\mathrm{A}$ \\
\hline & 122 & $\mathrm{Rp}$ & $\mathrm{Rp}$ & $\mathrm{Rp}$ & $\mathrm{A}$ \\
\hline & 132 & $\mathrm{Eg}$ & $\mathrm{Eg}$ & $\mathrm{Fg}$ & $\mathrm{A}$ \\
\hline \multirow{9}{*}{$\begin{array}{c}12^{\mathrm{a}} \quad \text { sessão } \\
\mathrm{N}=90\end{array}$} & 8 & $\mathrm{Rp}$ & $\mathrm{Rp}$ & $\mathrm{Rp}$ & $\mathrm{A}$ \\
\hline & 18 & $\mathrm{Cg}$ & $\mathrm{Cg}$ & $\mathrm{Cg}$ & $\mathrm{A}$ \\
\hline & 28 & $\mathrm{Rp}$ & $\mathrm{Rp}$ & $\mathrm{Rp}$ & $\mathrm{A}$ \\
\hline & 38 & $\mathrm{Cp}$ & $\mathrm{Cp}$ & $\mathrm{Cp}$ & $\mathrm{A}$ \\
\hline & 49 & $\mathrm{Ip}$ & $\mathrm{Ip}$ & Ip & $\mathrm{A}$ \\
\hline & 59 & $\mathrm{Rp}$ & $\mathrm{Rp}$ & $\mathrm{Rp}$ & $\mathrm{A}$ \\
\hline & 67 & Elp & Elp & Elp & $\mathrm{A}$ \\
\hline & 77 & $\mathrm{Rp}$ & $\mathrm{Rp}$ & $\mathrm{Rp}$ & $\mathrm{A}$ \\
\hline & 86 & $\mathrm{Eg}$ & $\mathrm{Eg}$ & $\mathrm{Eg}$ & $\overline{\mathrm{A}}$ \\
\hline \multirow{16}{*}{$\begin{array}{c}13^{\mathrm{a}} \quad \text { sessão } \\
\mathrm{N}=158\end{array}$} & 6 & $\mathrm{Rp}$ & $\mathrm{Rp}$ & $\mathrm{Rp}$ & $\mathrm{A}$ \\
\hline & 16 & Ip & $\mathrm{Rp}$ & $\mathrm{Rp}$ & $\mathrm{D}$ \\
\hline & 27 & Ip & Ip & Ip & $\mathrm{A}$ \\
\hline & 38 & $\mathrm{Rp}$ & $\mathrm{Rp}$ & $\mathrm{Rp}$ & $\mathrm{A}$ \\
\hline & 47 & $\mathrm{Rg}$ & $\mathrm{Rg}$ & $\mathrm{Rg}$ & $\bar{A}$ \\
\hline & 56 & $\mathrm{Rp}$ & $\mathrm{Rp}$ & $\mathrm{Rp}$ & $\mathrm{A}$ \\
\hline & 66 & $\mathrm{Rp}$ & $\mathrm{Rp}$ & $\mathrm{Rp}$ & $\mathrm{A}$ \\
\hline & 76 & Ip & Ip & Ip & $\mathrm{A}$ \\
\hline & 86 & $\mathrm{Rp}$ & $\mathrm{Cp}$ & Cp & $\mathrm{D}$ \\
\hline & 94 & $\mathrm{Rp}$ & $\mathrm{Rp}$ & $\mathrm{Rp}$ & A \\
\hline & 104 & Elp & Elp & Elp & $\mathrm{A}$ \\
\hline & 114 & $\mathrm{Rp}$ & $\mathrm{Rp}$ & $\mathrm{Rp}$ & $\mathrm{A}$ \\
\hline & 123 & $\mathrm{Ig}$ & $\mathrm{Ig}$ & $\mathrm{Ig}$ & $\mathrm{A}$ \\
\hline & 133 & $\mathrm{Ip}$ & Ip & Ip & $\mathrm{A}$ \\
\hline & 143 & Elp & Elp & Elp & $\mathrm{A}$ \\
\hline & 153 & $\mathrm{Eg}$ & $\mathrm{Eg}$ & $\mathrm{Eg}$ & $\mathrm{A}$ \\
\hline \multirow{10}{*}{$\begin{array}{c}14^{\mathrm{a}} \quad \text { sessão } \\
\mathrm{N}=143\end{array}$} & 4 & $\mathrm{Rp}$ & $\mathrm{Rp}$ & $\mathrm{Rp}$ & $\mathrm{A}$ \\
\hline & 14 & $\mathrm{Ip}$ & Ip & Ip & A \\
\hline & 24 & $\mathrm{Rp}$ & $\mathrm{Rp}$ & $\mathrm{Rp}$ & $\mathrm{A}$ \\
\hline & 34 & $\mathrm{Rp}$ & $\mathrm{Rp}$ & $\mathrm{Rp}$ & $\mathrm{A}$ \\
\hline & 44 & $\mathrm{Rp}$ & $\mathrm{Rp}$ & $\mathrm{Rp}$ & $\mathrm{A}$ \\
\hline & 54 & $\mathrm{Cp}$ & $\mathrm{Rp}$ & $\mathrm{Rp}$ & $\mathrm{A}$ \\
\hline & 64 & Elp & Elp & Elp & $\mathrm{A}$ \\
\hline & 74 & $\mathrm{Rp}$ & $\mathrm{Rp}$ & $\mathrm{Rp}$ & $\overline{\mathrm{A}}$ \\
\hline & 84 & $\mathrm{Rp}$ & $\mathrm{Rp}$ & $\mathrm{Rp}$ & A \\
\hline & 95 & $\mathrm{Rp}$ & $\mathrm{Rp}$ & $\mathrm{Rp}$ & $\mathrm{A}$ \\
\hline
\end{tabular}


Continuação..

\begin{tabular}{|c|c|c|c|c|c|}
\hline \multirow[t]{2}{*}{ Sessão } & \multirow[t]{2}{*}{ Intervenção } & \multicolumn{2}{|c|}{ Avaliadores } & \multirow{2}{*}{$\begin{array}{c}\text { Classificação } \\
\text { final }\end{array}$} & \multirow{2}{*}{$\begin{array}{c}\text { Acordo/ } \\
\text { desacordo }\end{array}$} \\
\hline & & 1 & 2 & & \\
\hline & 103 & $\mathrm{Rp}$ & $\mathrm{Rp}$ & $\mathrm{Rp}$ & $\mathrm{A}$ \\
\hline & 113 & $\mathrm{Rp}$ & $\mathrm{Rp}$ & $\mathrm{Rp}$ & $\mathrm{A}$ \\
\hline & 122 & $\mathrm{Rp}$ & $\mathrm{Rp}$ & $\mathrm{Rp}$ & $\overline{\mathrm{A}}$ \\
\hline & 135 & $R p$ & $\mathrm{Cp}$ & $\mathrm{Cp}$ & $\mathrm{D}$ \\
\hline \multirow{6}{*}{$\begin{array}{c}15^{\mathrm{a}} \quad \text { sessão } \\
\mathrm{N}=54\end{array}$} & 2 & $\mathrm{Rp}$ & $\mathrm{Rp}$ & $\mathrm{Rp}$ & A \\
\hline & 12 & $\mathrm{Rp}$ & $\mathrm{Rp}$ & $\mathrm{Rp}$ & A \\
\hline & 22 & $\mathrm{Rp}$ & $\mathrm{Rp}$ & $\mathrm{Rp}$ & $\mathrm{A}$ \\
\hline & 32 & $\mathrm{Rp}$ & $\mathrm{Ip}$ & $\mathrm{Ip}$ & $\mathrm{D}$ \\
\hline & 42 & Elp & Elp & Elp & $\mathrm{A}$ \\
\hline & 15 & $\mathrm{Rp}$ & $\mathrm{Rp}$ & $\mathrm{Rp}$ & $\mathrm{A}$ \\
\hline \multirow{17}{*}{$\begin{array}{c}16^{\mathrm{a}} \text { sess } \tilde{\mathfrak{d}} \\
\mathrm{N}=159\end{array}$} & 16 & Ap & Ap & Ap & $\mathrm{A}$ \\
\hline & 16 & $\mathrm{Eg}$ & $\mathrm{Eg}$ & $\mathrm{Eg}$ & $\mathrm{A}$ \\
\hline & 16 & Elp & Elp & Elp & A \\
\hline & 16 & Ip & Ip & ip & A \\
\hline & 16 & $\mathrm{Rp}$ & $\mathrm{Rp}$ & $\mathrm{Rp}$ & $\mathrm{A}$ \\
\hline & 16 & $R p$ & $R p$ & $\mathrm{Rp}$ & $\mathrm{A}$ \\
\hline & 16 & Ip & Ip & Ip & $\mathrm{A}$ \\
\hline & 16 & $\mathrm{Rp}$ & $\mathrm{Rp}$ & $\mathrm{Rp}$ & $\mathrm{A}$ \\
\hline & 16 & Ip & $\mathrm{Ip}$ & $\mathrm{Ip}$ & $\mathrm{A}$ \\
\hline & 16 & $\mathrm{Og}$ & $\mathrm{Og}$ & $\mathrm{Og}$ & $\mathrm{A}$ \\
\hline & 101 & Ip & Ep & Ep & $\mathrm{D}$ \\
\hline & 110 & $\mathrm{Rp}$ & $\mathrm{Rp}$ & $\mathrm{Rp}$ & A \\
\hline & 120 & Ap & $\mathrm{Ap}$ & $\mathrm{Ap}$ & $\mathrm{A}$ \\
\hline & 131 & $\mathrm{Rp}$ & $\mathrm{Rp}$ & $\mathrm{Rp}$ & $\mathrm{A}$ \\
\hline & 141 & Elg & Elg & Elg & $\mathrm{A}$ \\
\hline & 151 & $\mathrm{Ag}$ & $\mathrm{Ag}$ & $\mathrm{Ag}$ & $\mathrm{A}$ \\
\hline & 152 & $\mathrm{Eg}$ & $\mathrm{Eg}$ & $\mathrm{Eg}$ & $\mathrm{A}$ \\
\hline
\end{tabular}




\section{ANEXO 4 \\ (QUESTIONÁRIO DO INCIDENTE CRÍTICO)}

Nome:

Data:

ESTAMOS PEDINDO PARA VOCÊ RESPONDER ESSAS QUESTÕES PARA CONHECER A SUA OPINIÃO SOBRE O GRUPO. A SUA SINCERIDADE NAS RESPOSTAS É MUITO IMPORTANTE. NÃO SE PEOCUPE COM QUE OS OUTROS PENSAM, PARA NÓS O QUE IMPORTA É A SUA OPINIÃO. ESSAS INFORMAÇÕES SÃO SIGILOSAS E APENAS OS PESQUISADORES SABERÃO DE SUA RESPOSTA. SEJA VERDADEIRO. SE TIVER QUALQUER DÚVIDA, CHAME O PESQUISADOR.

OBRIGADA, CARLA.

1-) NO GRUPO DE HOJE, QUAL O ACONTECIMENTO QUE FOI MAIS IMPORTANTE PARA VOCÊ?

2-) CONTE COM DETALHES COMO FOI ESTE ACONTECIMENTO: QUAIS AS PESSOAS ENVOLVIDAS E O QUE ELAS FIZERAM?

3-) QUAL FOI SUA REAÇÃO DURANTE ESTE ACONTECIMENTO? (COMO VOCÊ SE SENTIU / O QUE VOCÊ PENSOU / O QUE VOCÊ FEZ).

4-) POR QUE VOCÊ ACHA QUE ESTE ACONTECIMENTO FOI IMPORTANTE PRA VOCÊ? 


\begin{abstract}
ANEXO 5
MANUAL DE CLASSIFICAÇÃO DOS FATORES TERAPÊUTICOS - Bloch, S. Crouch, E., e Holroyd, P.\& Themem, J. (1979) A method for the study of psychotherapeutic factors in group psychotherapy. British Journal of Psychiatry, 134, 257-263.Trad: Emerson Fernando Rasera - mestrando em Psicologia pela FFCLRP-USP.
\end{abstract}

Sua tarefa é codificar cada "evento importante" oferecido pelos pacientes e terapeutas em um dos dez fatores terapêuticos, usando as definições e os exemplos dos fatores apresentados no Manual. Instruções para a codificação:

(1) Apesar de você se familiarizar com os conteúdos do Manual no treinamento, será necessário consultar freqüientemente ̀̀ definições e exemplos durante a codificação. Você sempre terá que fazer distinções refinadas entre os fatores - o exame freqüente do Manual o ajudará a fazer estas distinções.

(2) Ao decidir sobre qual fator você designará para um evento, você deverá considerar o relato todo como uma unidade. Isto é verdadeiro inclusive nos casos em que a extensão do relato fornece informações subsidiárias (como situando o evento em um contexto). Não focalize exclusivamente na razão do respondente para selecionar um evento particular ou exclusivamente em alguma palavra chave ou frase do relato.

(3) Na codificação, a questão norteadora é: "como este evento é importante para este paciente em particular?" (em oposição ao grupo ou ao terapeuta, por exemplo).

(4) Apesar de você poder encontrar eventos relatados aos quais possa ser designados mais de um fator terapêutico, selecione apenas um fator. No evento relatado, o paciente ou o terapeuta enfatizará algum significado terapêutico particular do evento. Escolha um fator que melhor represente esta ênfase. Você também poderá ser ajudado em sua decisão observando a razão do respondente para selecionar um evento particular.

(5) Alguns relatos incluem comentários sobre o comportamento do paciente subseqüente ao "evento mais importante" apontado. (Este comportamento pode estar na mesma sessão ou em sessões posteriores). Estes comentários não deverão ser considerados como "novos eventos importantes", mas deverão ser tratados como evidência que dará substância ao impacto do "evento importante" relatado.

\title{
Cartarse
}

A base da catarse é a liberação emocional; por exemplo, a ventilação de sentimentos, tanto positivos quanto negativos, e tanto sobre eventos da vida ou de outros membros do grupo, que podem trazer certa medida de alívio.

Este fator opera quando o paciente:

- libera sentimentos no grupo - tanto de material passado como do aqui e agora (levando ao alívio).

- expressa sentimentos, como raiva, afeição, tristeza, e pesar que eram previamente difíceis ou impossíveis de liberar (levando ao alívio). 
Continuação...

\section{Auto-revelação}

A base da auto-revelação é o ato de revelar informações pessoais ao grupo. Difere da catarse que está relacionada à liberação de sentimentos e da aprendizagem através da ação interpessoal que está relacionada à tentativa de se relacionar adaptativa e construtivamente com outros membros do grupo.

Este fator opera quando o paciente:

- revela informações, tanto sobre sua vida fora do grupo como de seu passado, ou de seus medos e dificuldades, ou problemas, ou de suas fantasias, as quais ele considera íntimas e pessoais.

- revela e divide informações pessoais mesmo que tal revelação e compartilhar possam ser difíceis ou dolorosos.

\section{Aprendizagem através da ação interpessoal}

A base deste fator é a tentativa de se relacionar construtiva e adaptativamente no grupo, tanto iniciando algum comportamento ou respondendo a outros membros do grupo. Mais importante do que a reação dos membros do grupo é o esforço para do paciente para se relacionar construtiva e adaptativamente. (veja auto-revelação para observar as diferenças entre catarse, auto-revelação e aprendizagem através da ação interpessoal; veja também altruísmo para observar diferenças entre este e a aprendizagem através da ação interpessoal).

Este fator opera quando o paciente:

- tenta maneiras novas e potencialmente positivas de iniciar o comportamento com outros membros do grupo. Estas maneiras podem incluir: 1-) expressar-se para outros membros do grupo para clarificar sua relação com eles; 2-) realizar um esforço explícito e público para desenvolver uma relação de forma mais honesta e aberta como outros membros do grupo; 3-) expressar-se de forma mais construtivamente assertiva; 4-) expressar-se para alcançar intimidade com outros membros do grupo; 5-) tenta maneiras novas e potencialmente positivas de responder para outros membros do grupo - por exemplo, com maior sensibilidade ou com aceitação apropriada de crítica.

\section{Universalidade}

Este fator opera quando o paciente:

- reconhece que os seus problemas não são singulares,

- percebe que outros membros do grupo têm problemas similares e isto reduz seu senso de singularidade.

- experiencia a sensação que não está sozinho com seus sentimentos e problemas. 
Continuação...

\section{Aceitação}

Este fator opera quando o paciente:

- experimenta um sentimento de pertencimento, acolhimento, amizade e conforto no grupo.

- $\quad$ sente-se valorizado por outros membros do grupo.

- valoriza o apoio que o grupo lhe oferece.

- sente-se cuidado, apoiado, entendido e aceito por outros membros do grupo.

- sente-se incondicionalmente aceito e apoiado mesmo quando ele revela algo sobre si mesmo que considerava anteriormente como inaceitável.

\footnotetext{
Altruísmo

A base do altruísmo é que o paciente pode se sentir melhor a respeito de si mesmo, e/ou aprender algo positivo sobre si, através da ajuda a outros membros do grupo. Altruísmo difere da aprendizagem através da ação interpessoal no fato de que em seus esforços para ajudar outros membros do grupo, o paciente melhora sua auto-imagem porque aprende que ele pode ser útil aos outros. Apesar da aprendizagem através da ação interpessoal poder envolver comportamento altruísta, o valor terapêutico está nas ações do paciente mais do que nos efeitos daquelas em sua auto-imagem.

Este fator opera quando o paciente:

- oferece apoio, segurança, sugestões ou comentários para ajudar outros membros do grupo.

- compartilha problemas similares com o propósito de ajudar outros membros do grupo.

- sente-se necessário e útil.

- $\quad$ pode esquecer de si mesmo em favor de outro membro do grupo.

- reconhece que quer fazer algo por outro membro do grupo.
}

\section{Orientação}

Este fator opera quando o paciente:

- recebe informações importantes e instruções do terapeuta sobre saúde mental, doença mental ou psicodinâmica geral (não pessoal).

- recebe conselho, sugestões e orientação explícitos sobre seus problemas, tanto do terapeuta quanto de outros pacientes. 
Continuação...

\section{Auto-entendimento}

A base do auto-entendimento é que o paciente aprende algo importante sobre si mesmo, Ele pode surgir como resultado do feedback (direto ou indireto) e da interpretação de outros membros do grupo, tanto dos pacientes como do terapeuta.

Este fator opera quando o paciente:

- aprende algo importante sobre seu comportamento, suas concepções, motivações, fantasias ou pensamentos inconscientes.

- aprende como ele é percebido por outros membros do grupo.

- aprende porque ele se comporta da forma que o faz e como ele chegou a ser da forma que ele é.

- aprende mais claramente sobre a natureza de seus problemas.

\section{Aprendizagem vicária}

A base da aprendizagem vicária é que o paciente experiencia algo de valor para ele mesmo, através da observação de outros membros do grupo, incluindo o terapeuta.

Este fator opera quando o paciente:

- beneficia-se da observação da experiência de terapia de outro paciente.

- identifica-se com outro membro do grupo a ponto de beneficiar-se da experiência de terapia deste.

- reconhece alguns aspectos positivos do comportamento do terapeuta, ou de outros membros, para imitar.

- pode encontrar modelos no comportamento positivo de outros membros do grupo (incluindo o terapeuta) em direção à qual ele pode se esforçar.

\section{Instilação de esperança}

A base da instilação de esperança é que o paciente ganha um senso de otimismo sobre seu progresso, sobre seu potencial para o progresso, por seu tratamento na terapia de grupo. Ele difere da aprendizagem vicária na qual o paciente vê como outros membros do grupo melhoram. Na instilação de esperança o paciente vê que outros membros do grupo melhoram.

Este fator opera quando o paciente:

- vê que outros membros do grupo melhoram ou estão melhorando.

- vê que o grupo pode ser útil para seus membros no trabalho voltado para seus objetivos.

- sente-se otimista sobre o potencial de ajuda do grupo, por exemplo, "estou esperançoso que, ou sinto que o grupo irá me ajudar"; "eu posso ver que o grupo está me levando para algum lugar". 


\section{ANEXO 6}

História dos pacientes referente a período anterior a seu atendimento no serviço, contendo dados acerca do tempo de apresentação do quadro clínico, história de internação psiquiátrica e uso de medicação anterior.

\begin{tabular}{|c|c|c|c|c|}
\hline Pacientes & $\begin{array}{c}\text { Duração do } \\
\text { quadro clínico }\end{array}$ & $\begin{array}{l}\text { Tratamentos } \\
\text { anteriores }\end{array}$ & $\begin{array}{c}\text { Uso de } \\
\text { medicação }\end{array}$ & $\begin{array}{l}\text { História de } \\
\text { internação }\end{array}$ \\
\hline ROBERTA & Não consta & Não consta & $\begin{array}{l}\text { Medicação } \\
\text { ansiolítica }\end{array}$ & Nega \\
\hline JOÃO & Não consta & $\begin{array}{l}\text { Participação em } \\
\text { grupo terapêutico }\end{array}$ & $\begin{array}{l}\text { Medicação } \\
\text { ansiolítica }\end{array}$ & Nega \\
\hline ANA MARIA & Não consta & $\begin{array}{l}\text { Refere acompanha- } \\
\text { mento psiquiátrico } \\
\text { anterior }\end{array}$ & $\begin{array}{c}\text { Medicação } \\
\text { ansiolítica e } \\
\text { antidepressiva }\end{array}$ & $\begin{array}{c}\text { Não refere } \\
\text { (mas houve } \\
\text { situações de } \\
\text { crise) }\end{array}$ \\
\hline MARTA & $\begin{array}{l}\text { Refere fazer } \\
\text { tratamento há } \\
\text { seis anos }\end{array}$ & $\begin{array}{l}\text { Refere tratamentos } \\
\text { psiquiátricos, em } \\
\text { diferentes serviços }\end{array}$ & $\begin{array}{l}\text { Medicação } \\
\text { antipsicótica } \\
\text { (benzamida) }\end{array}$ & $\begin{array}{l}\text { Refere semi- } \\
\text { internação } \\
\text { (Hosp.Dia) }\end{array}$ \\
\hline MARLI & $\begin{array}{l}\text { Mais de vinte e } \\
\text { cinco anos }\end{array}$ & $\begin{array}{l}\text { Refere tratamentos } \\
\text { psiquiátricos em } \\
\text { diferentes serviços }\end{array}$ & $\begin{array}{l}\text { Refere o uso de } \\
\text { medicação, mas } \\
\text { não especifica }\end{array}$ & $\begin{array}{l}\text { Refere onze } \\
\text { internações } \\
\text { psiquiátricas }\end{array}$ \\
\hline IRENE & $\begin{array}{l}\text { Referência a } \\
\text { período de três } \\
\text { meses }\end{array}$ & $\begin{array}{l}\text { Refere acompanha- } \\
\text { mento psiquiátrico } \\
\text { anterior }\end{array}$ & $\begin{array}{c}\text { Medicação } \\
\text { ansiolítica e } \\
\text { antidepressiva }\end{array}$ & Nega \\
\hline ESTELA & $\begin{array}{c}\text { Há mais de um } \\
\text { ano }\end{array}$ & $\begin{array}{l}\text { Negou tratamento } \\
\text { psiquiátrico anterior }\end{array}$ & Não refere & Nega \\
\hline VALTER & Não consta & $\begin{array}{l}\text { Refere ter sido } \\
\text { encaminhado para } \\
\text { tratamento psicoló- } \\
\text { gico, mas não ter } \\
\text { comparecido }\end{array}$ & $\begin{array}{l}\text { Medicação } \\
\text { ansiolítica }\end{array}$ & Nega \\
\hline ROSILENE & $\begin{array}{c}\text { Há cerca de oito } \\
\text { anos }\end{array}$ & $\begin{array}{l}\text { Refere tratamentos } \\
\text { psiquiátricos em } \\
\text { diferentes serviços }\end{array}$ & $\begin{array}{l}\text { Medicação } \\
\text { ansiolítica }\end{array}$ & Nega \\
\hline MARÍLIA & Não consta & Não consta & $\begin{array}{c}\text { Medicações } \\
\text { antidepressivas } \\
\text { e ansiolíticas }\end{array}$ & Nega \\
\hline
\end{tabular}




\section{ANEXO 7}

História clínica psiquiátrica dos pacientes antecedendo o encaminhamento para o grupo e a partir do início de seu atendimento no serviço, incluindo história da moléstia atual, condutas, evolução, as principais queixas referidas, os diagnósticos (CID-10) e as condutas médicas tomadas no período.

\begin{tabular}{|c|c|c|c|c|}
\hline Pacientes & início & História da Moléstia & Diagnóstico & Condutas \\
\hline ROBERTA & fev/97 & $\begin{array}{l}\text { Queixas orgânicas: palpi- } \\
\text { tação, coração dispara, } \\
\text { acha que vai desmaiar; } \\
\text { teme que tenha problema } \\
\text { cardíaco, ou derrame; } \\
\text { insônia; problemas de } \\
\text { relacionamento conjugal; } \\
\text { medo de andar de ônibus, } \\
\text { medo de sair na } \\
\text { multidão; angústia e } \\
\text { ansiedade; }\end{array}$ & $\begin{array}{l}\text { Transtornos } \\
\text { de ansiedade }\end{array}$ & $\begin{array}{l}\text { Prescrição de medica- } \\
\text { ção ansiolítica. Em } \\
\text { outros atendimentos } \\
\text { teve medicação e } \\
\text { diagnóstico revistos, e } \\
\text { sua medicação foi } \\
\text { suspensa ao final. } \\
\text { Também participou } \\
\text { de sessões de um } \\
\text { grupo de apoio. }\end{array}$ \\
\hline JOÃO & out/97 & $\begin{array}{l}\text { Queixa-se de problemas } \\
\text { de relacionamento conju- } \\
\text { gal, em função de sua } \\
\text { esposa ser paciente } \\
\text { psiquiátrica; problemas } \\
\text { financeiros; obesidade; } \\
\text { nervoso e agressividade. }\end{array}$ & $\begin{array}{l}\text { Transtorno } \\
\text { adaptativo }\end{array}$ & $\begin{array}{l}\text { Não teve indicação de } \\
\text { seguimento medica- } \\
\text { mentoso; consultas de } \\
\text { apoio e orientação } \\
\text { individual, até o início } \\
\text { do grupo. }\end{array}$ \\
\hline ANA MARIA & ago/96 & $\begin{array}{l}\text { Crises depressivas; dores } \\
\text { de cabeça; angústia; } \\
\text { irritação, indisposição e } \\
\text { implicância com fami- } \\
\text { liares; problemas de } \\
\text { relacionamento afetivo } \\
\text { com o marido; angústia; } \\
\text { choro constante; }\end{array}$ & \begin{tabular}{|l|} 
Transtorno \\
depressivo \\
recorrente, \\
episódio atual \\
moderado
\end{tabular} & $\begin{array}{l}\text { Em vários momentos } \\
\text { teve seu diagnóstico e } \\
\text { medicação revistos; } \\
\text { uso recorrente e des- } \\
\text { contínuo de medica- } \\
\text { ção desde o início do } \\
\text { atendimento; crises } \\
\text { depressivas recorren- } \\
\text { tes; iniciou atendi- } \\
\text { mento psicológico } \\
\text { individual, mas aban- } \\
\text { donou; participação } \\
\text { em grupo de apoio } \\
\text { anterior. }\end{array}$ \\
\hline MARTA & set/97 & $\begin{array}{l}\text { Refere problemas de } \\
\text { relacionamento com os } \\
\text { pais, acusando a mãe de } \\
\text { ser psicopata; não } \\
\text { consegue ficar sozinha, } \\
\text { não tem disposição para } \\
\text { trabalhar; desânimo, } \\
\text { tristeza e desinteresse; }\end{array}$ & $\begin{array}{l}\text { Transtorno } \\
\text { esquizotímico }\end{array}$ & $\begin{array}{l}\text { Seguimento medica- } \\
\text { mentoso, sem muitas } \\
\text { alterações, e encami- } \\
\text { nhamento para o } \\
\text { grupo }\end{array}$ \\
\hline
\end{tabular}


Continuação...

\begin{tabular}{|c|c|c|c|c|}
\hline MARLI & Jun/96 & $\begin{array}{l}\text { Relato de angústia, } \\
\text { esquecimento, insônia, } \\
\text { alucinações; tentativa } \\
\text { anterior de suicídio; } \\
\text { irritação, desânimo, } \\
\text { tristeza; sente que todos } \\
\text { estão olhando para ela; } \\
\text { medo de que algo ruim } \\
\text { lhe aconteça; dificul- } \\
\text { dades na realização de } \\
\text { atividades domésticas. }\end{array}$ & Distimia & $\begin{array}{l}\text { Medicação constante- } \\
\text { mente revista durante } \\
\text { seu atendimento no } \\
\text { serviço. Participação } \\
\text { em outros dois grupos } \\
\text { de apoio; interrupções } \\
\text { no uso da medicação } \\
\text { por conta própria. }\end{array}$ \\
\hline IRENE & Fev/98 & $\begin{array}{l}\text { Insônia, perda de peso, } \\
\text { chorava o dia todo; } \\
\text { dificuldade } \\
\text { realizar as atividades } \\
\text { domésticas, dificuldade } \\
\text { para respirar e andar } \\
\text { direito. }\end{array}$ & Distimia & $\begin{array}{ll}\text { Medicação } & \text { constan- } \\
\text { temente } & \text { revista a } \\
\text { longo de } & \text { seus atendi- } \\
\text { mentos; } & \text { apresentou } \\
\text { diminuição no uso de } \\
\text { medicação. }\end{array}$ \\
\hline ESTELA & Fev/98 & $\begin{array}{l}\text { Pensa em se matar } \\
\text { quando as coisas não } \\
\text { dão certo; há um ano } \\
\text { começou quadro de } \\
\text { escurecer a vista, perda } \\
\text { de peso e inapetência. }\end{array}$ & $\begin{array}{l}\text { Ansiedade } \\
\text { Generalizada }\end{array}$ & $\begin{array}{l}\text { A avaliação médica } \\
\text { indicou que a paciente } \\
\text { não tinha indicação } \\
\text { para seguimento medi- } \\
\text { camentoso, e apenas foi } \\
\text { indicada para aten- } \\
\text { dimento no grupo. }\end{array}$ \\
\hline VALTER & Out/97 & $\begin{array}{l}\text { Sono extremo, náuseas, } \\
\text { vômitos; Sente gosto de } \\
\text { sangue na boca e vai } \\
\text { em pânico para o } \\
\text { hospital. }\end{array}$ & $\begin{array}{l}\text { Transtorno } \\
\text { hipocondríaco }\end{array}$ & $\begin{array}{l}\text { Medicação antidepres- } \\
\text { siva e ansiolítica, } \\
\text { revista ao longo de seus } \\
\text { atendimentos. Refe- } \\
\text { rência ao fato de } \\
\text { interromper o uso da } \\
\text { medicação por conta } \\
\text { própria. }\end{array}$ \\
\hline ROSILENE & Jan/98 & $\begin{array}{l}\text { Dificuldades de relacio- } \\
\text { namento com o marido; } \\
\text { ansiedade; palpitação; } \\
\text { uso abusivo de medi- } \\
\text { cação ansiolítica. }\end{array}$ & $\begin{array}{l}\text { Transtorno } \\
\text { Dissociativo } \\
\text { anestesia e } \\
\text { perda } \\
\text { sensorial } \\
\text { dissociativas }\end{array}$ & $\begin{array}{ll}\text { Uso de medicação } \\
\text { ansiolítica, mas não } \\
\text { teve outras consultas no } \\
\text { serviço, mesmo no } \\
\text { período em que } \\
\text { participou do grupo. }\end{array}$ \\
\hline MARÍLIA & $\mathrm{Jul} / 98$ & $\begin{array}{l}\text { Depressão acentuada; } \\
\text { come demais, tristeza, } \\
\text { inquietação, angústia e } \\
\text { mal estar; medo de ficar } \\
\text { sozinho, de dias } \\
\text { chuvosos. }\end{array}$ & Distimia & $\begin{array}{l}\text { Uso recorrente e } \\
\text { descontínuo de medica- } \\
\text { ção no período; me- } \\
\text { dicação revista cons- } \\
\text { tantemente. Participa- } \\
\text { ção em outros grupos. }\end{array}$ \\
\hline
\end{tabular}




\section{ANEXO 8 \\ Condição dos pacientes no momento de encaminhamento para o} grupo, tendo em vista suas principais queixas, seus diagnósticos (CID-10) e o uso ou não de medicação.

\begin{tabular}{|c|c|c|c|}
\hline Pacientes & Principais queixas & Diagnóstico & Medicação \\
\hline ROBERTA & $\begin{array}{l}\text { Dificuldades de } \\
\text { conjugal elacionamento } \\
\text { afetiva; desânimo e anbivalência }\end{array}$ & $\begin{array}{l}\text { Transtornos de } \\
\text { Ansiedade }\end{array}$ & $\begin{array}{l}\text { Sem indicação para } \\
\text { seguimento } \\
\text { medicamentoso. }\end{array}$ \\
\hline JOÃO & $\begin{array}{l}\text { Mais calmo, situação familiar e } \\
\text { profissional relativamente mais } \\
\text { estável . Sem outras queixas. }\end{array}$ & $\begin{array}{l}\text { Transtorno } \\
\text { Adaptativo }\end{array}$ & $\begin{array}{l}\text { Sem indicação para } \\
\text { seguimento } \\
\text { medicamentoso. }\end{array}$ \\
\hline ANA MARIA & $\begin{array}{l}\text { Encontra-se relativamente bem, } \\
\text { melhor em relação à queixas } \\
\text { depressivas, mais animada e } \\
\text { disposta. Refere estar } \\
\text { conseguindo realizar atividades } \\
\text { de trabalho e desejo de voltar a } \\
\text { estudar, e retomar suas } \\
\text { atividades de pintura. }\end{array}$ & $\begin{array}{l}\text { Transtorno } \\
\text { depressivo } \\
\text { recorrente, } \\
\text { episódio atual } \\
\text { moderado }\end{array}$ & $\begin{array}{l}\text { Uso de medicação } \\
\text { ansiolítica: } \\
\text { bromazepan } 6 \mathrm{mg} \\
(0-0-1 / 2)\end{array}$ \\
\hline MARTA & $\begin{array}{l}\text { Dificuldades emocionais que } \\
\text { associa a problemas de } \\
\text { relacionamento com a mãe; } \\
\text { queixa-se de desinteresse e } \\
\text { sente-se incapaz de procurar } \\
\text { emprego. }\end{array}$ & $\begin{array}{l}\text { Transtorno } \\
\text { Esquizotímico } \\
\text { (alterado depois } \\
\text { para Transtorno } \\
\text { de personalidade } \\
\text { borderline) }\end{array}$ & $\begin{array}{l}\text { Medicação } \\
\text { antipsicótica: } \\
\text { Sulpirida 200mg } \\
(0-0-1 / 2)\end{array}$ \\
\hline MARLI & $\begin{array}{l}\text { Queixa-se de "cabeça grande", } \\
\text { irritabilidade, medo de que algo } \\
\text { ruim lhe aconteça e por isso } \\
\text { ficando em casa. Diz que fica } \\
\text { contrariada sem motivo, refere } \\
\text { insônia. }\end{array}$ & Distimia & $\begin{array}{l}\text { Medicação antide- } \\
\text { pressiva e ansiolítica: } \\
\text { Imipramina } 25 \mathrm{mg}(1- \\
1-2)\end{array}$ \\
\hline IRENE & $\begin{array}{l}\text { Refere estar cansada das tarefas } \\
\text { domésticas, dificuldade para } \\
\text { respirar e andar direito. }\end{array}$ & Distimia & $\begin{array}{l}\text { Medicação antide- } \\
\text { pressiva e ansiolitica: } \\
\text { Amitriptilina 25mg } \\
(1-0-1) \text { e Lorazepan } \\
1 \mathrm{mg}(0-0-1)\end{array}$ \\
\hline ESTELA & $\begin{array}{l}\text { Refere pensar em se matar } \\
\text { quando as coisas não dão certo, } \\
\text { mas negou planejamento de } \\
\text { suicídio; quadro de escurecer a } \\
\text { vista, inapetência, perda de } \\
\text { peso. }\end{array}$ & $\begin{array}{c}\text { Ansiedade } \\
\text { Generalizada }\end{array}$ & $\begin{array}{l}\text { Sem indicação para } \\
\text { seguimento } \\
\text { medicamentoso }\end{array}$ \\
\hline
\end{tabular}


Continuação...

\begin{tabular}{|c|l|c|l|}
\hline Pacientes & \multicolumn{1}{|c|}{ Principais queixas } & \multicolumn{1}{|c|}{ Diagnóstico } & \multicolumn{1}{c|}{ Medicação } \\
\hline VALTER & $\begin{array}{l}\text { Sente náuseas, vômitos, indo em } \\
\text { pânico para o hospital; sono } \\
\text { extremo }\end{array}$ & $\begin{array}{c}\text { Transtorno } \\
\text { hipocondríaco } \\
\text { (alterado } \\
\text { depois para } \\
\text { Ansiedade } \\
\text { Generalizada) }\end{array}$ & $\begin{array}{l}\text { Medicação antide- } \\
\text { pressivo e ansiolítico: } \\
\text { Diazepan 5mg (0-0-1) e } \\
\text { fluoxetina 20mg (1-0- } \\
0) .\end{array}$ \\
\hline ROSILENE & $\begin{array}{l}\text { Uso abusivo de tranqüilizantes, } \\
\text { problemas de relacionamento } \\
\text { com o ex-marido; ansiedade; }\end{array}$ & $\begin{array}{c}\text { Transtorno } \\
\text { Dissociativo, } \\
\text { anestesia e } \\
\text { perda } \\
\text { sensorial } \\
\text { dissociativas }\end{array}$ & $\begin{array}{l}\text { Medicação ansiolítica: } \\
\text { Diazepan 10mg (0-1-1) }\end{array}$ \\
\hline MARÍLIA & $\begin{array}{l}\text { Refere estar melhor das queixas } \\
\text { de ansiedade e depressão, } \\
\text { permanecendo há sete meses } \\
\text { assintomática, desde que use a } \\
\text { medicação. }\end{array}$ & $\begin{array}{l}\text { Distimia } \\
\text { pressiva e ansiolítica: } \\
\text { Imipramina 25mg } \\
(0-0-3)\end{array}$ \\
\hline
\end{tabular}


ANEXO 9: AVALIAÇÃO DA CONDIÇÃO PSICOSSOCIAL DOS PACIENTES AO INÍCIO E AO TÉRMINO DO GRUPO

\begin{tabular}{|c|c|c|c|c|c|c|c|c|c|c|c|c|c|c|c|c|c|c|c|c|c|c|c|}
\hline \multirow{2}{*}{\multicolumn{2}{|c|}{$\begin{array}{c}\text { Avaliação do ajustamento } \\
\text { psicossocial }\end{array}$}} & \multicolumn{22}{|c|}{ Pacientes } \\
\hline & & \multicolumn{2}{|c|}{ Roberta } & \multicolumn{2}{|c|}{ João } & \multicolumn{2}{|c|}{ A. Maria } & \multicolumn{2}{|c|}{ Marta } & \multicolumn{2}{|c|}{ Marli } & \multicolumn{2}{|c|}{ Irene } & \multicolumn{2}{|c|}{ Estela } & \multicolumn{2}{|c|}{ Valter } & \multicolumn{2}{|c|}{ Rosilene } & \multicolumn{2}{|c|}{ Marília } & \multicolumn{2}{|c|}{ TOTAL } \\
\hline aspecto & índices & pré & pós & pré & pós & pré & pós & pré & pós & pré & pó & $\mathrm{pr}$ & pó & $\mathrm{pr}$ & & ré & pós & pré & pós & pré & pós & pré & pós \\
\hline \multirow{3}{*}{$\begin{array}{l}\text { Afetivo- } \\
\text { relacional }\end{array}$} & muita dificuldade & $\mathrm{X}$ & & $\mathrm{X}$ & & $X$ & $X$ & $X$ & $\mathrm{X}$ & & & & & & & & & & $\mathrm{X}$ & & & 4 & 3 \\
\hline & $\begin{array}{l}\text { Alguma } \\
\text { dificuldade }\end{array}$ & & $\mathrm{X}$ & & & & & & & $\mathrm{X}$ & $X$ & $\mathrm{X}$ & $\Lambda$ & $\mathrm{X}$ & & $\mathrm{X}$ & & $\mathrm{X}$ & & $\mathrm{X}$ & $\mathrm{X}$ & 6 & 5 \\
\hline & Sem dificuldade & & & & $\mathrm{X}$ & & & & & & & & & & & & $\mathrm{X}$ & & & & & 0 & 2 \\
\hline \multirow[t]{3}{*}{ odutivo $^{P r}$} & $\begin{array}{l}\text { Não consegue } \\
\text { exercer atividades }\end{array}$ & & & & & & & & $\mathrm{X}$ & & & & & & & & & & & & & 0 & 1 \\
\hline & $\begin{array}{l}\text { Alguma } \\
\text { dificuldade }\end{array}$ & $\mathrm{X}$ & $\mathrm{X}$ & $\mathrm{X}$ & $\mathrm{X}$ & $\mathrm{X}$ & $X$ & $\mathrm{X}$ & & $X$ & $X$ & & & & & & & $\mathrm{X}$ & $\mathrm{X}$ & $\mathrm{X}$ & $\mathrm{X}$ & 7 & 6 \\
\hline & Sem dificuldades & & & & & & & & & & & $\mathrm{X}$ & $X$ & $X$ & & $X$ & $\mathrm{X}$ & & & & & 3 & 3 \\
\hline \multirow{3}{*}{$\begin{array}{c}\text { Sócio- } \\
\text { Cultural }\end{array}$} & Muita dificuldade & & & & & & & & & & & & & & & & & & & & & 0 & 0 \\
\hline & \begin{tabular}{|l|} 
Alguma \\
dificuldade \\
\end{tabular} & $\mathrm{X}$ & $\mathrm{X}$ & $\mathrm{X}$ & $\mathrm{X}$ & $\mathrm{X}$ & $X$ & $\mathrm{X}$ & $\mathrm{X}$ & $X$ & & $\mathrm{X}$ & & & & $X$ & & $\mathrm{X}$ & $\mathrm{X}$ & $\mathrm{X}$ & $\mathrm{X}$ & 9 & 6 \\
\hline & Sem dificuldades & & & & & & & & & & $X$ & & $X$ & $X$ & & & $\mathrm{X}$ & & & & & 1 & 4 \\
\hline \multirow{3}{*}{$\begin{array}{l}\text { Capacida } \\
\text {-de Adap- } \\
\text { tativa }\end{array}$} & Muito limitada & & & & & $\mathrm{X}$ & $X$ & $X$ & & $X$ & & & & & & & & & $\mathrm{X}$ & & & 3 & 2 \\
\hline & $\begin{array}{l}\text { Limitada } \\
\text { parcialmente }\end{array}$ & $\mathrm{X}$ & $\mathrm{X}$ & $\mathrm{X}$ & & & & & $\mathrm{X}$ & & $\mathrm{X}$ & $\mathrm{X}$ & $\mathrm{X}$ & $\mathrm{X}$ & & & & $\mathrm{X}$ & & $\mathrm{X}$ & $\mathrm{X}$ & 6 & 5 \\
\hline & Não está limitada & & & & $\mathrm{X}$ & & & & & & & & & & & $\mathrm{X}$ & $\mathrm{X}$ & & & & & 1 & 3 \\
\hline \multirow{3}{*}{$\begin{array}{l}\quad \text { A } \\
\text { valiação } \\
\text { Global } \\
\text { (início) }\end{array}$} & $\begin{array}{l}\text { Ajustamento psico } \\
\text {-social prejudicado }\end{array}$ & & & & & $\mathrm{X}$ & & $X$ & & & & & & & & & & & & & & 2 & - \\
\hline & $\begin{array}{l}\text { Ajustamento psico } \\
\text {-social razoável }\end{array}$ & $\mathrm{X}$ & & $\mathrm{X}$ & & & & & & $\mathrm{X}$ & & $\mathrm{X}$ & & $\mathrm{X}$ & & $\mathrm{X}$ & & $\mathrm{X}$ & & $\mathrm{X}$ & & 8 & - \\
\hline & $\begin{array}{l}\text { Bom ajustamento } \\
\text { psicossocial }\end{array}$ & & & & & & & & & & & & & & & & & & & & & - & - \\
\hline \multirow{3}{*}{$\begin{array}{c}\text { Avaliação } \\
\text { Global } \\
\text { (término) }\end{array}$} & Piorou & & & & & & & & & & & & & & & & & & & & & - & - \\
\hline & Sem alteração & & & & & & $\mathrm{X}$ & & $\mathrm{X}$ & & $X$ & & $X$ & & & & & & $\mathrm{X}$ & & $\mathrm{X}$ & - & 6 \\
\hline & Melhorou & & $\mathrm{X}$ & & $\mathrm{X}$ & & & & & & & & & & & & $\mathrm{X}$ & & & & & - & 4 \\
\hline
\end{tabular}




\begin{abstract}
ANEXO 10
Informações sobre o seguimento dos pacientes durante um período de quatro meses após o término do grupo, relativo a principais queixas, uso de medicação e outros procedimentos.
\end{abstract}

\begin{tabular}{|c|c|}
\hline Pacientes & Seguimento após o grupo \\
\hline ROBERTA & $\begin{array}{l}\text { Recebeu alta do grupo em julho de } 98 \text {, e estava na lista de espera para } \\
\text { participação de um novo grupo, pois solicitou ao médico que viesse a } \\
\text { participar novamente. Porém, convocada para triagem em set/98 não } \\
\text { compareceu, não mais retornando ao serviço. }\end{array}$ \\
\hline JOÃO & $\begin{array}{l}\text { Recebeu alta do grupo de apoio do grupo, não mais comparecendo para } \\
\text { atendimento na PQU. }\end{array}$ \\
\hline ANA MARIA & $\begin{array}{l}\text { Não continuou em outro grupo, embora tivesse recebido indicação ao } \\
\text { término do grupo. Atendida em julho'98, apresentando-se mais calma do } \\
\text { que quando o grupo terminou, mas ainda com choro fácil. Mantido o } \\
\text { mesmo medicamento ansiolítico - Bromazepan 6mg (0-0-1/2). Em } \\
\text { setembro retorna ao serviço, apontando dificuldades de relacionamento } \\
\text { com a filha, tendo sido a mesma conduta médica Ainda mostrava-se com } \\
\text { descontrole emocional. Comparece ao serviço em out/98, em crise. Choro } \\
\text { constante, depressiva e com comportamentos impulsivos, e com alteração } \\
\text { no ciclo de sono. A conduta médica foi de aumento de medicação: } \\
\text { bromazepan } 6 \mathrm{mg}(1 / 2-0-1 / 2) \text { e Amitriptilina } 25 \mathrm{mg}(0-0-3) \text {. Em nov/98 } \\
\text { retornou ao serviço, tendo melhorado das queixas depressivas, mais } \\
\text { animada e satisfeita. }\end{array}$ \\
\hline MARTA & $\begin{array}{l}\text { Iniciou participação em outro grupo de apoio, abandonando a partir da } \\
\text { segunda sessão. Atendida em ago/98 referiu estar melhor, embora ainda } \\
\text { desanimada. Fez referência ao fato de estar procurando emprego. Mantido } \\
\text { diagnóstico de Transtorno de Personalidade Borderline e medicação } \\
\text { antipsicótica Sulpirida 20mg (0-0-1).Em out/98 apontou estar sem } \\
\text { medicação já há dois meses, e se sentindo bem. Não refere alteração de } \\
\text { sono ou apetite ou outras queixas e recebe alta da PQU. }\end{array}$ \\
\hline MARLI & $\begin{array}{l}\text { Não participa de outro grupo. Atendida individualmente em ago/98 refere } \\
\text { estar melhor em relação æ̇ queixas depressivas, sem angústia e crises de } \\
\text { choro; mantém queixas de tristeza, dizendo acreditar que não vale a pena } \\
\text { viver, mas nega ideação suicida. Refere lavar as mãos e tomar banho várias } \\
\text { vezes por dia; perda de peso. Diagnóstico de distimia, acrescido de suspeita } \\
\text { de quadro de demência em instalação e de transtorno obsessivo } \\
\text { compulsivo. Aumento da medicação antidepressiva: Imipramina } 25 \mathrm{mg}(1- \\
\text { 1-2). Em consultas seguintes teve seu medicamento aumentado para (2-1- } \\
\text { 2), apresentando-se angustiada com seu déficit cognitivo. Em nov/98 diz } \\
\text { melhor das queixas depressivas, mas angustiada com esquecimento. } \\
\text { Diminui por conta própria o medicamento. Última prescrição médica foi de } \\
\text { Imipramina } 25 \mathrm{mg}(1-1-2) \text { e marcado retorno para jan/ } 99 \text {. }\end{array}$ \\
\hline
\end{tabular}


Continuação...

\begin{tabular}{|c|c|}
\hline Pacientes & Seguimento após o grupo \\
\hline IRENE & $\begin{array}{l}\text { Seguiu acompanhamento medicamentoso no serviço, apresentando-se sem } \\
\text { queixas depressivas. Manteve o uso de medicamento anterior - } \\
\text { Amitriptilina 25mg (1-0-2)e Lorazepan } 1 \mathrm{mg}(0-0-1 / 2) \text {. Ao longo dos } \\
\text { atendimentos, teve a dosagem diminuída. Em nov/98 queixava-se de } \\
\text { problemas de relacionamento com o marido, e certa tristeza. Medicação } \\
\text { mantida e retorno agendado para fev/99. }\end{array}$ \\
\hline ESTELA & Após a participação do grupo, recebeu alta, não mais retornando no serviço \\
\hline VALTER & $\begin{array}{l}\text { Tendo recebido alta do grupo de apoio, foi marcado retorno para ago'98, } \\
\text { ao qual não compareceu. }\end{array}$ \\
\hline ROSILENE & Faltou nas últimas sessões do grupo e não há outros registros em sua pasta. \\
\hline MARÍLIA & $\begin{array}{l}\text { Atendida após o grupo, referindo problemas de relacionamento com a filha, } \\
\text { humor lábil e depressivo, referindo cansaço e desânimo. Refere ansiedade e } \\
\text { apetite aumentada. Seguimento medicamentoso: Imipramina } 25 \mathrm{mg}(2-0-3) \\
\text { e Diazepan 5mg (0-0-1). Mesmo procedimento em nov/98 e retorno } \\
\text { marcado para dez/98. }\end{array}$ \\
\hline
\end{tabular}


ANEXO 11

Freqüência dos participantes no grupo de apoio no período de março a julho de 1998

\begin{tabular}{|c|c|c|c|c|c|c|c|c|c|c|c|}
\hline $\begin{array}{l}\text { Data/ } \\
\text { nome }\end{array}$ & 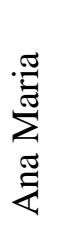 & 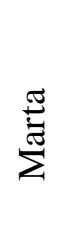 & 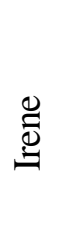 & $\overline{\bar{z}}$ & 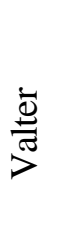 & $\begin{array}{l}\frac{\pi}{\mathbb{U}} \\
\frac{\pi}{\tilde{I}} \\
\tilde{I}\end{array}$ & 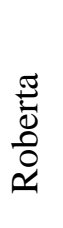 & 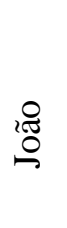 & 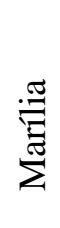 & 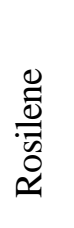 & $\begin{array}{l}\bar{\pi} \\
\tilde{0} \\
H\end{array}$ \\
\hline $1^{a}$ & $X$ & $\mathrm{X}$ & $X$ & $X$ & $X$ & $X$ & $X$ & $X$ & & $X$ & 09 \\
\hline $2^{a}$ & $X$ & $X$ & $X$ & $X$ & $X$ & $X$ & & $X$ & & $X$ & 08 \\
\hline $3^{a}$ & $X$ & $X$ & $X$ & $X$ & $X$ & $X$ & $X$ & & & & 07 \\
\hline $4^{a}$ & $X$ & $X$ & $X$ & $X$ & & $X$ & & & $X$ & & 06 \\
\hline $5^{a}$ & $X$ & $X$ & $X$ & $X$ & $X$ & & $X$ & $X$ & & $X$ & 08 \\
\hline $6^{a}$ & $X$ & $X$ & $X$ & $X$ & $X$ & $X$ & & & $X$ & & 07 \\
\hline $7^{a}$ & $X$ & $X$ & & $X$ & & $X$ & & & $X$ & $X$ & 06 \\
\hline $8^{a}$ & $X$ & $X$ & $X$ & & $X$ & & & $X$ & $X$ & & 06 \\
\hline $9^{a}$ & $X$ & $X$ & $X$ & $X$ & $X$ & $X$ & $X$ & $X$ & & & 08 \\
\hline $10^{\mathrm{a}}$ & $X$ & $X$ & $X$ & $X$ & $\mathrm{X}$ & $X$ & $X$ & & $X$ & $X$ & 09 \\
\hline $11^{\mathrm{a}}$ & $X$ & $X$ & $X$ & $X$ & $X$ & & $X$ & $X$ & $X$ & & 08 \\
\hline $12^{\mathrm{a}}$ & $X$ & $X$ & & $X$ & & $X$ & & & & & 04 \\
\hline $13^{\mathrm{a}}$ & $X$ & $X$ & $X$ & $X$ & & $X$ & $X$ & $X$ & & & 07 \\
\hline $14^{\mathrm{a}}$ & $\mathrm{X}$ & $\mathrm{X}$ & $X$ & & $X$ & $X$ & $X$ & & $X$ & $X$ & 08 \\
\hline $15^{a}$ & $X$ & $X$ & $X$ & & $X$ & & $X$ & $X$ & & & 06 \\
\hline $16^{a}$ & $X$ & $X$ & $X$ & $X$ & $X$ & & $X$ & $X$ & & & 07 \\
\hline F & 16 & 16 & 14 & 13 & 12 & 11 & 10 & 09 & 07 & 06 & $x=7$ \\
\hline
\end{tabular}


ANEXO 12

Distribuição percentual das intervenções do coordenador em cada sessão do grupo $(\mathrm{N}=1904)$ pelas categorias de intervenção.

$1^{\text {a }}$ sessão $(\mathrm{N}=71)$

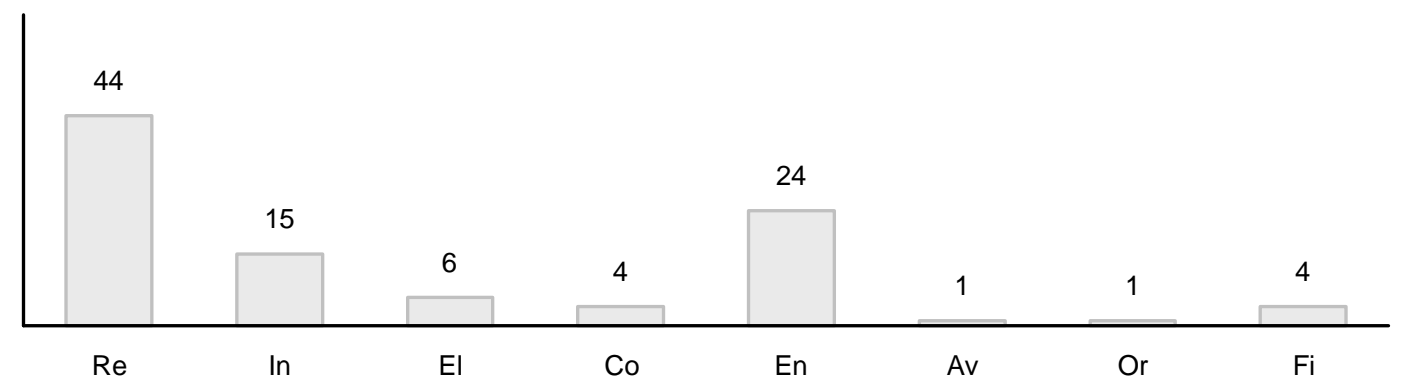

$2^{\mathrm{a}}$ sessão $(\mathrm{N}=106)$

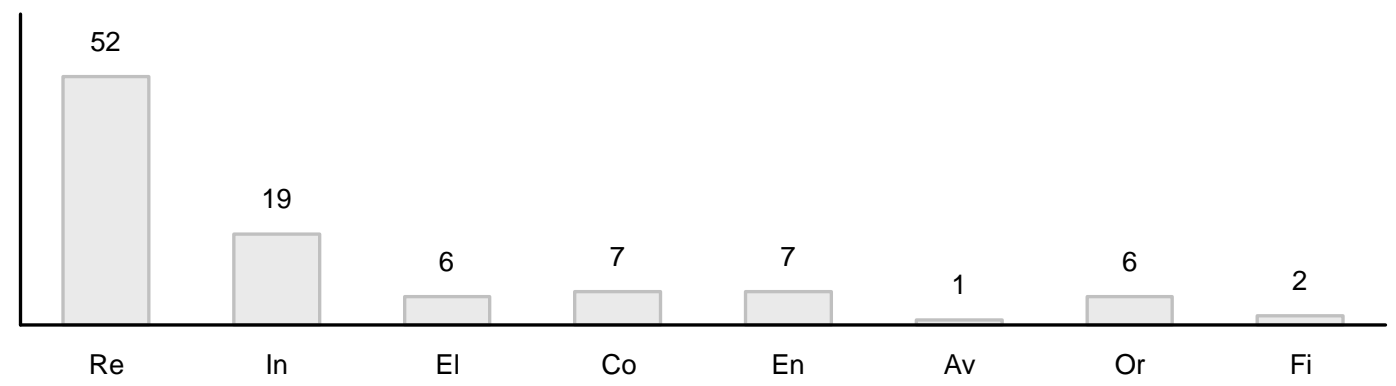

$3^{\mathrm{a}}$ sessão $(\mathrm{N}=128)$
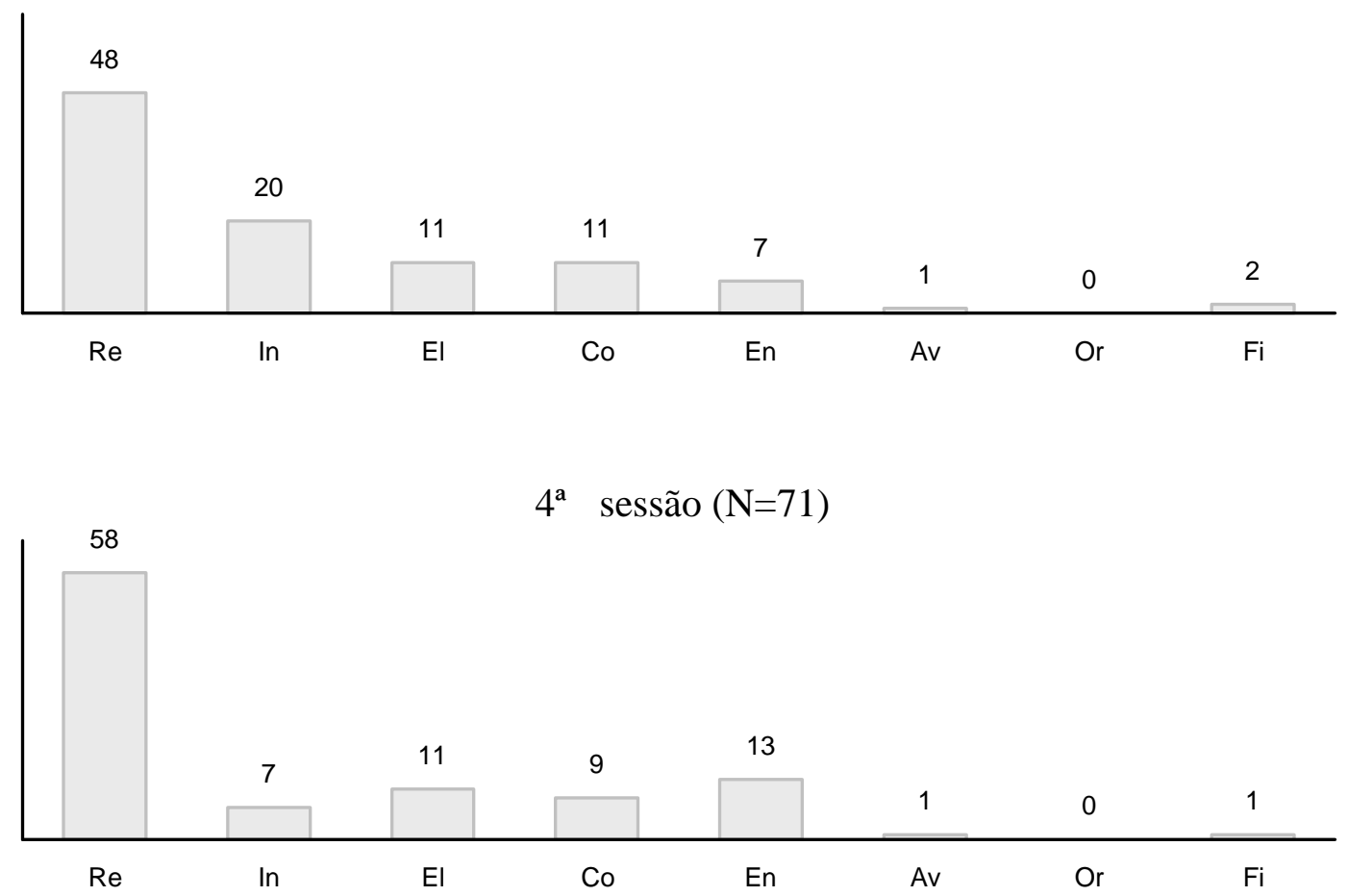

continua 
continuação...

$5^{\mathrm{a}}$ sessão $(\mathrm{N}=126)$
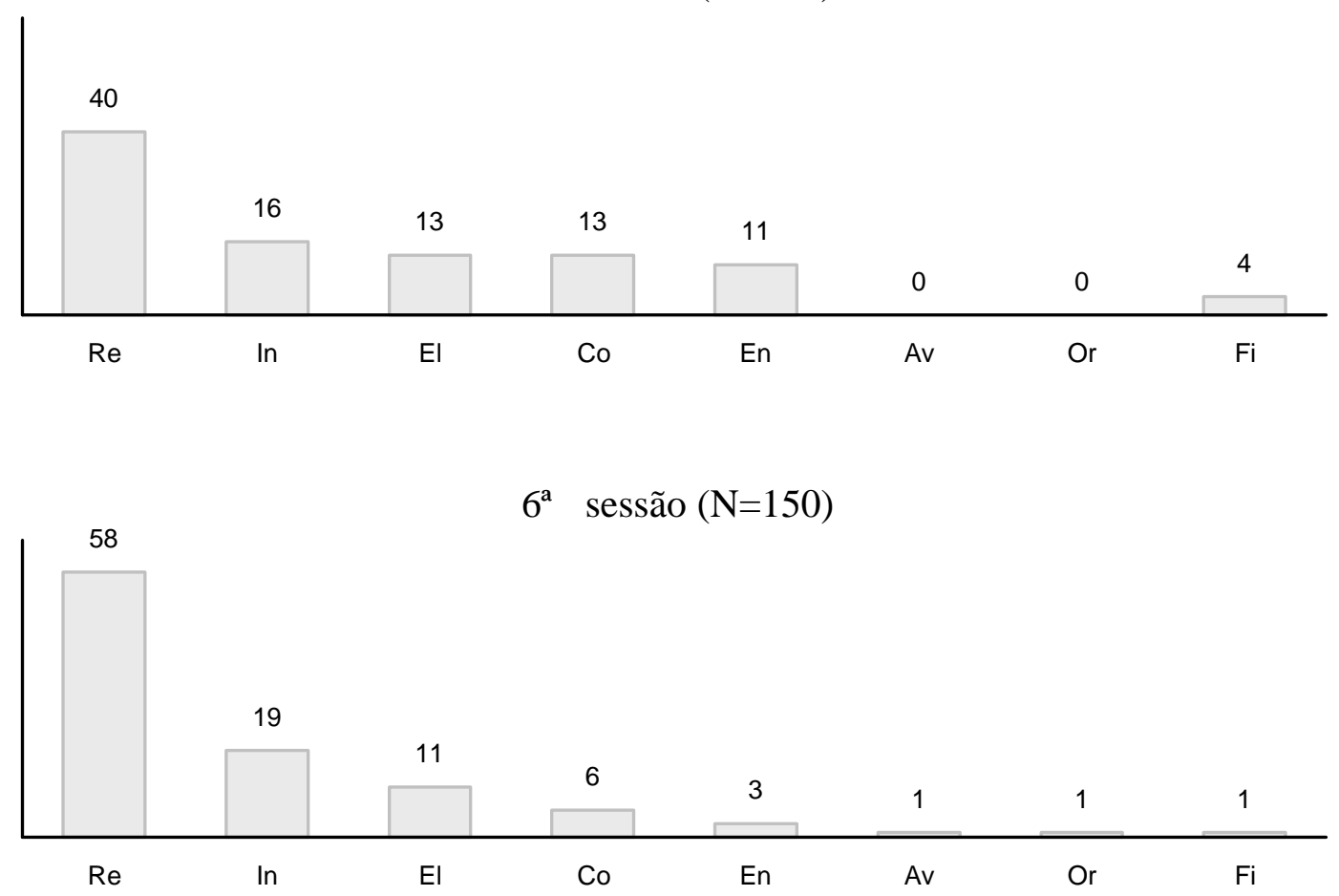

$7^{\mathrm{a}} \quad$ sessão $(\mathrm{N}=158)$

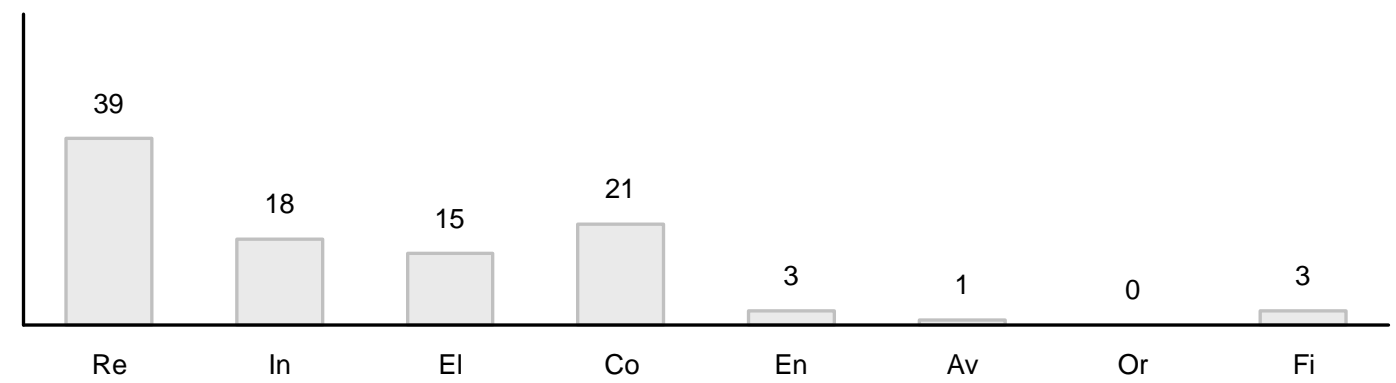

$8^{\mathrm{a}}$ sessão $(\mathrm{N}=114)$

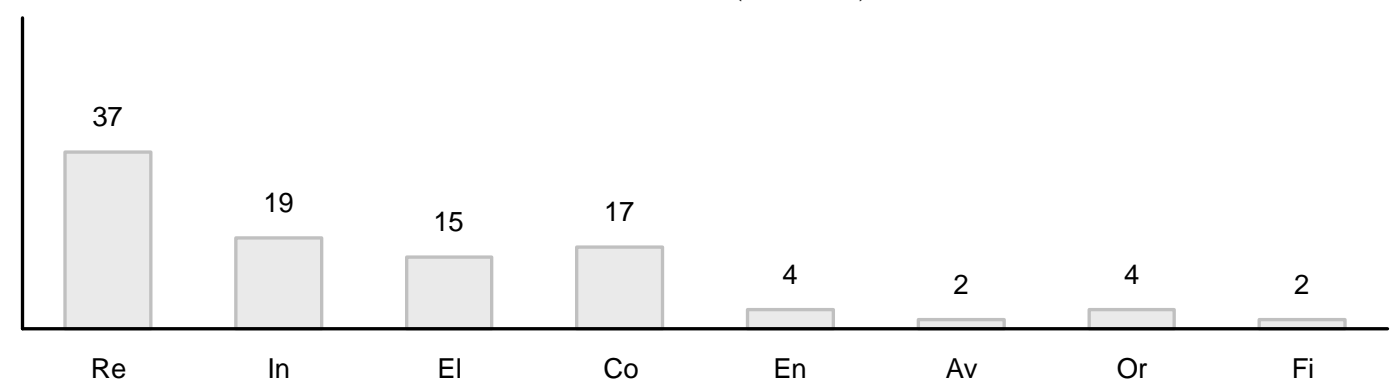

continua 
continuação...

$9^{a}$ sessão $(N=93)$

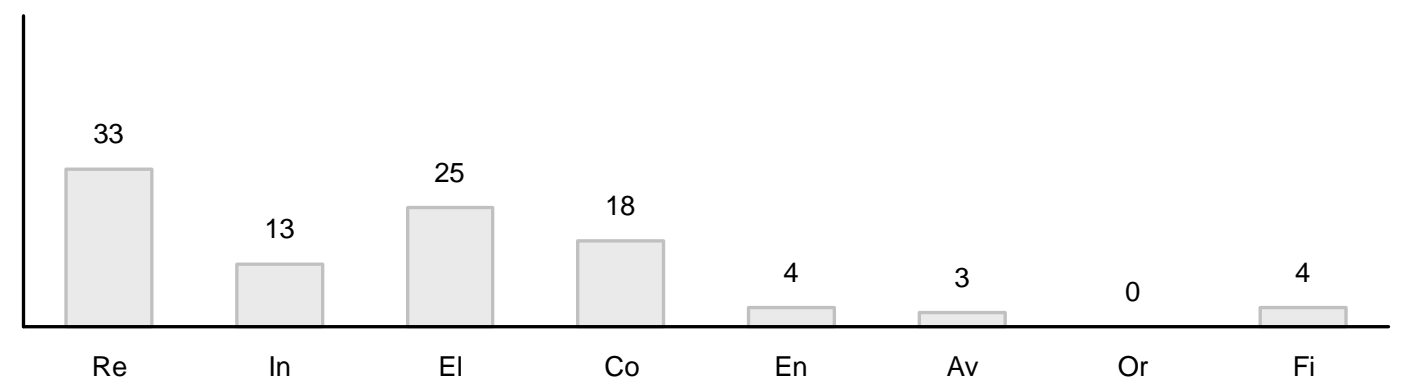

$10^{\mathrm{a}}$ sessão $(\mathrm{N}=147)$
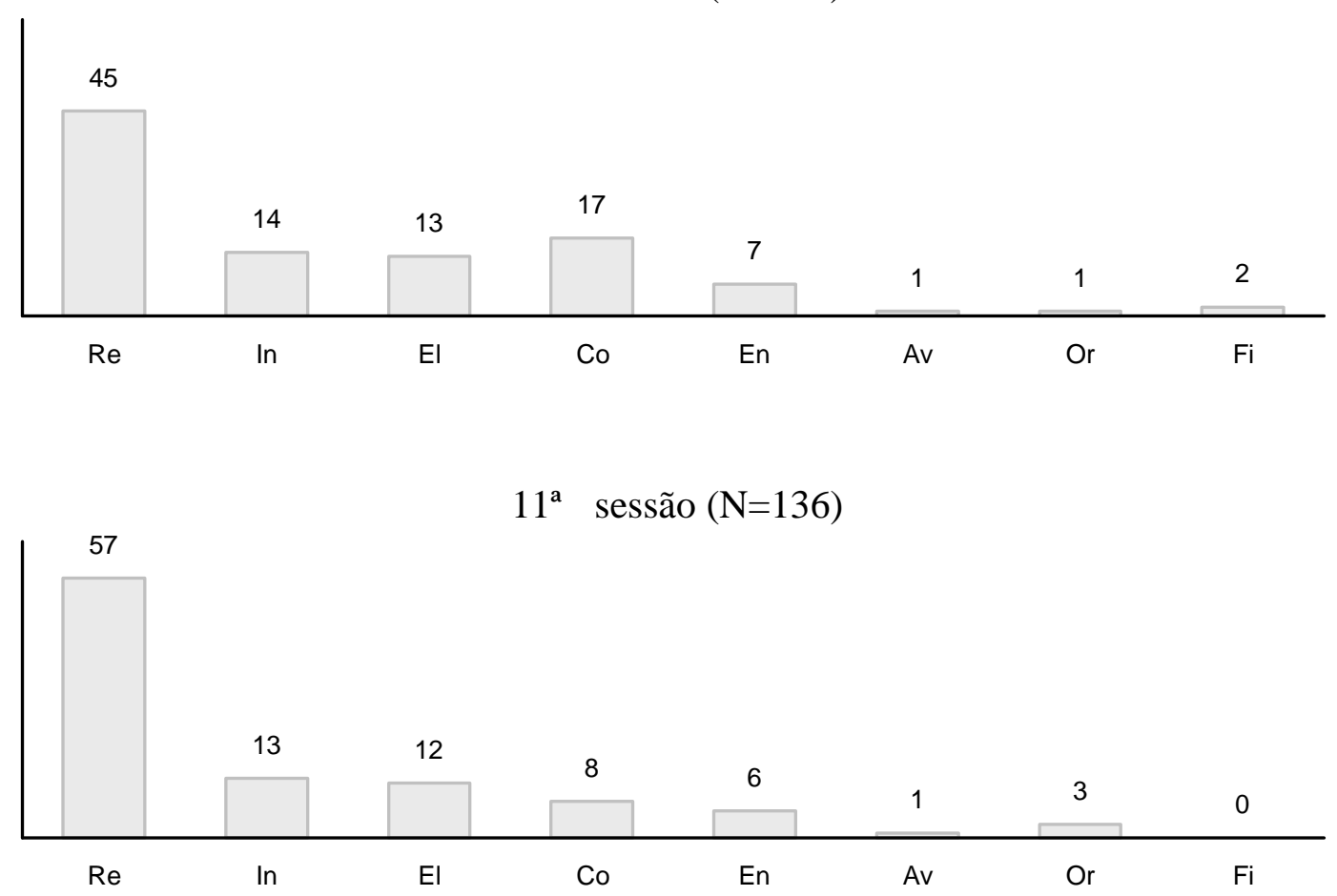

$12^{\mathrm{a}}$ sessão $(\mathrm{N}=190)$

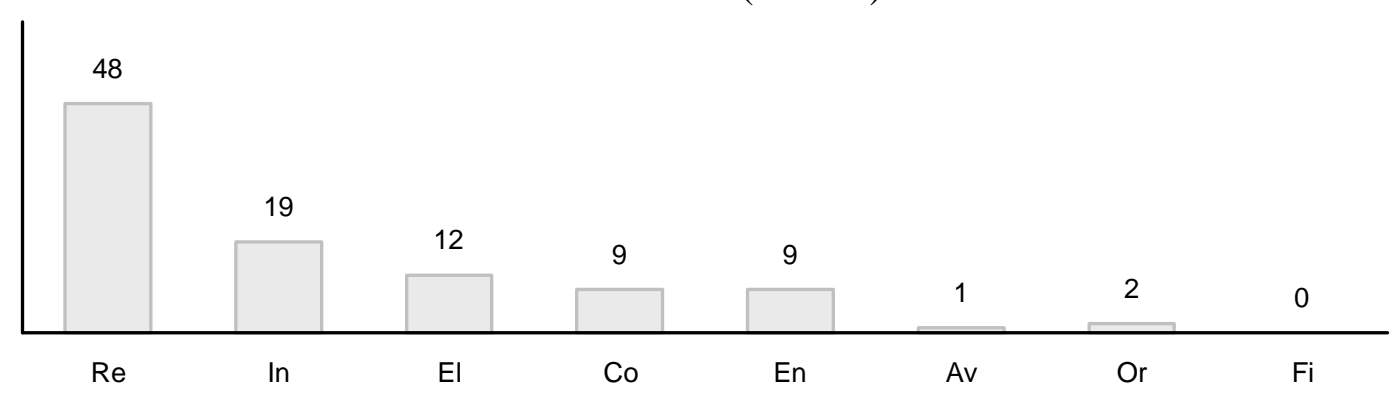

continua 
continuação...

$13^{\mathrm{a}}$ sessão $(\mathrm{N}=158)$

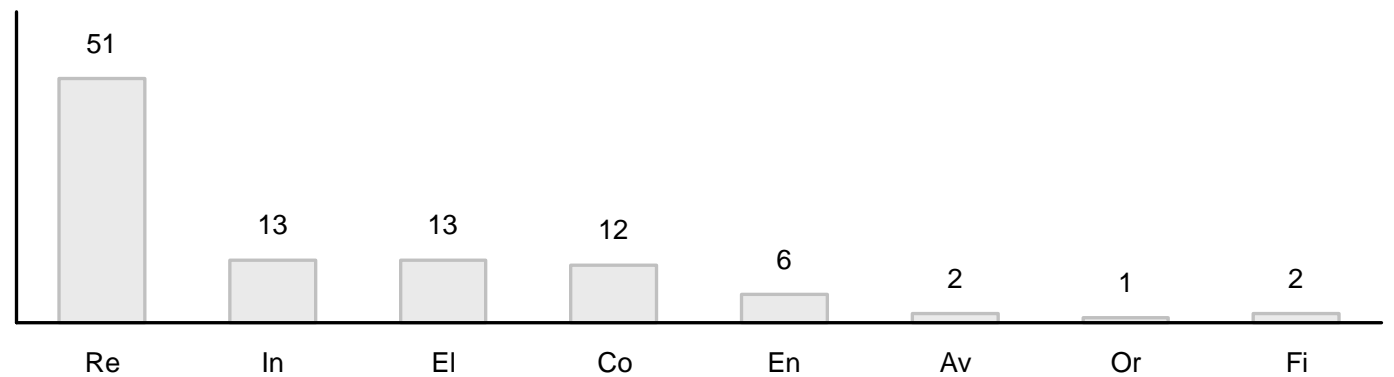

$14^{\mathrm{a}}$ sessão $(\mathrm{N}=143)$

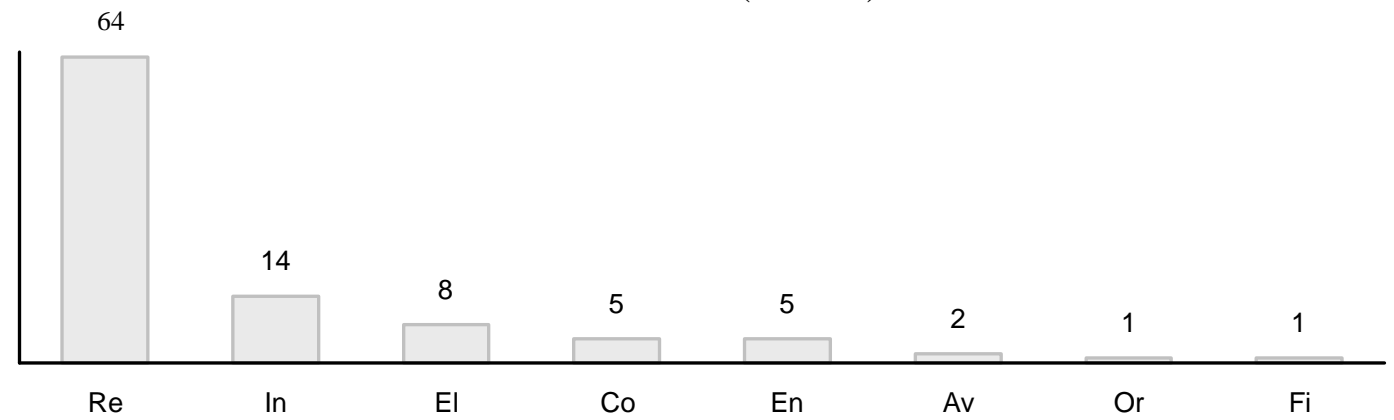

$15^{\mathrm{a}}$ sessão $(\mathrm{N}=54)$

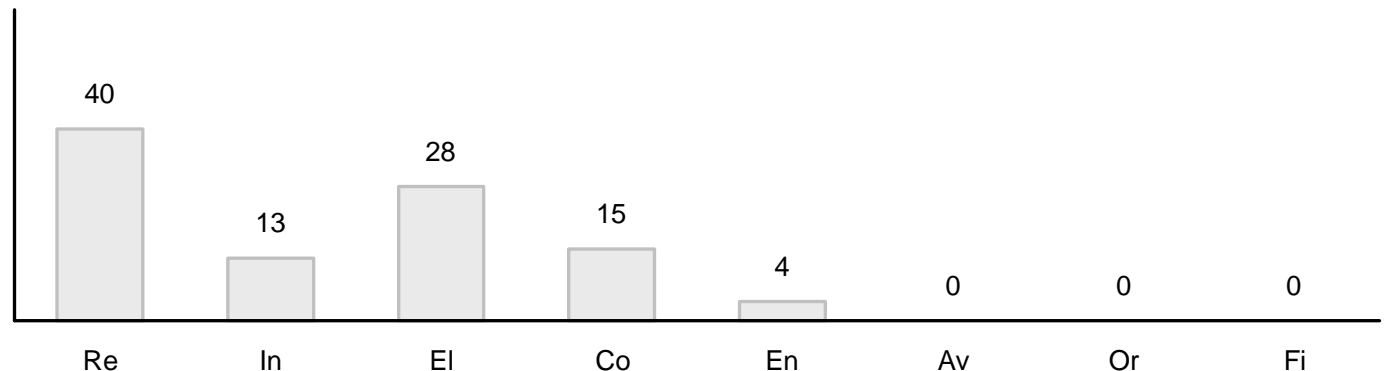

$16^{\mathrm{a}}$ sessão $(\mathrm{N}=159)$

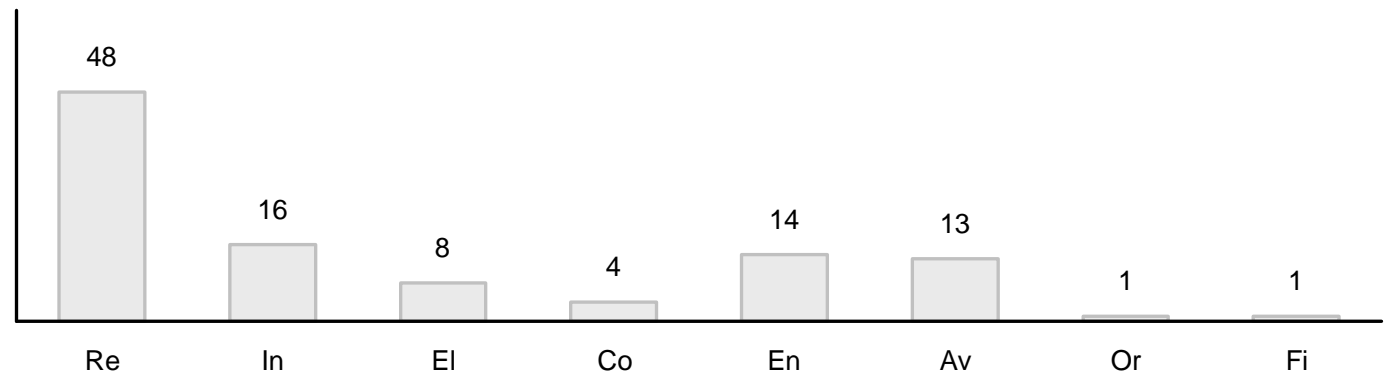




\section{0- REFERÊNCIAS BIBLIOGRÁFICAS}

Alves, D. S. N., Seidl, F., Schichtmam, A., \& Silva, R.C. (1994). Reestruturação da atenção em Saúde mental: situação atual, diretrizes e estratégias. In P. Amarante. (org). Psiquiatria Social e Reforma Psiquiátrica (pp.195-202). Rio de Janeiro: Editora Fiocruz.

Agapetus, L. (1994). Yalom's Model - Applied to an outpatient better breathers group. Journal of Psychosocial Nursing, 32, 11-14.

Amarante, P. (1994). Asilos, alienados e alienistas - pequena história da psiquiatria no Brasil. In P. Amarante (org). Psiquiatria Social e Reforma Psiquiátrica (pp.73-84). Rio de Janeiro: Editora Fiocruz.

Azima, F. J. C. (1996). Psicoterapia de grupo com transtornos de personalidade. In Kaplan, H.I., \& Sadock, B.J. Compêndio de Psicoterapia de Grupo ( $3^{\text {a }}$ ed., p.327338). Porto Alegre: Artes Médicas.

Bandeira, M., \& Soares, N.L. (1996). Desinstitucionalização: estão os profissionais de saúde mental bem informados? Jornal Brasileiro de Psiquiatria, 45, 159-165.

Bardin, L. (1988). Análise de Conteúdo. Lisboa: Edições 70.

Barros, D. D. (1994). Cidadania versus periculosidade social: a desintitucionalização como desconstrução de um saber. In P. Amarante (org). Psiquiatria Social e Reforma Psiquiátrica (pp:171-194). Rio de Janeiro: Editora Fiocruz.

Basaglia, F., Ongaro, F. B., Casagrande, D., Juvis, G., Comba, L. J., Pirella, A.; Schittar, L., \& Slavich, A. (1994). Considerações sobre uma experiência comunitária. In P. Amarante (org). Psiquiatria Social e Reforma Psiquiátrica (pp.1140). Rio de Janeiro: Editora Fiocruz.

Bezerra Junior, B. (1992).Considerações sobre terapêuticas ambulatoriais em saúde mental. In S.A.Tunis \& N.R.Costa (org). Cidadania e Loucura - Políticas de Saúde Mental no Brasil , ( $3^{\text {a }}$ ed. pp..133169). Petrópolis: Vozes. 
Birman, J., \& Costa, J. F. (1994). Organização das instituições para uma reforma comunitária. In P. Amarante (org). Psiquiatria Social e Reforma Psiquiátrica (pp.41-72). Rio de Janeiro: Editora Fiocruz.

Bloch, S., Reibstein, J., Crouch, E., Holroyd, P., \& Themen, J. (1979). A method for the study of therapeutic factors in group psychoterapy. British Journal of Psychiatry, 134, 257-263.

Brasil. Ministério da Saúde (1996). Resolução n 196/96 Sobre Pesquisa Envolvendo Seres Humanos. Brasília: Conselho Nacional de Saúde.

Brook, D. W (1996). Psicoterapia de grupo com transtornos de ansiedade e de humor. In H.I. Kaplan \& B.J.Sadock Compêndio de Psicoterapia de Grupo ( $3^{\mathrm{a}} \mathrm{ed}$, pp:310-325). Porto Alegre: Artes Médicas.

Budman, S. H., Simeone, P. G., Reilly, R., \& Demby, A .(1994). Progress in Short-term and Time Limited Group Psychotherapy: Evidence and Implications. In A. Fuhriman \& G.M. Burlingame (1994): Handbook of group psychotherapy - an empirical and clinical synthesis (pp.319-339). New York: John Wiley.

Calil, L. C., Silva, A. A., Sakuray, M. (1993). Tratamento em grupo de pacientes psicóticos. Jornal Brasileiro de Psiquiatria, 42, 537-540.

Campos, M. A. (1997).A hospitalização diurna em psiquiatria cinqüenta anos depois - um olhar ao longo do tema e do tempo. In E. M. Marturano, S. R. Loureiro, A. W. Zuardi (org) Estudos em Saúde Mental (pp.253-263). Ribeirão Preto: Comissão de Pós graduação em Saúde mental da Faculdade de Medicina de Ribeirão Preto - Universidade de São Paulo.

Cesarino, A. C. (1989). Uma experiência de Saúde Mental na Prefeitura de São Paulo (Projeto de Ações Integradas de Saúde Mental na Zona Norte do Município de São Paulo: uma gestão democrática de um projeto público de saúde mental). In A. Lancetti (org). Saúde e Loucura - grupos e coletivos, $\left(2^{\mathrm{a}}\right.$ ed., $\mathrm{n}^{\mathrm{o}} 1$, pp.03-32). São Paulo: Hucitec.

Conselho Regional de Psicologia, $6^{\mathrm{a}}$ região (1997). Trancar não é tratar liberdade é o melhor remédio ( $2^{\mathrm{a}}$ ed.). São Paulo. 
Contel, J. O. B. (1997). Psicoterapia de Grupo para Pacientes Internados e Egressos. In D.E.Zimermam \& L.C. Osório et.al. (1997). Como Trabalhamos com Grupos (cap.24, pp. 269-279). Porto Alegre: Artes Médicas.

Cordás, T. A., Nardi, A. E., Moreno, R. A., Castel, S. (org) (1997). Distimia do Mau Humor ao Mal do Humor (pp.53-67). Porto Alegre: Artes Médicas.

Cordiolli, A. V. (1998). Psicoterapias: abordagens atuais $\left(2^{\mathrm{a}}\right.$ ed.). Porto Alegre: Artes Médicas.

Costa, N. R., \& Tunis, S. A. (1992). Cidadania, classes populares e doença mental. In S. A. Tunis, \& N. R.Costa (org). Cidadania e Loucura - Políticas de Saúde Mental no Brasil ( $3^{\mathrm{a}}$ ed., pp.0913). Petrópolis: Vozes.

Costa-Rosa, A. (s/d). Escala diagnóstica adaptativa operacionalizada (EDAO): uma proposta de quantificação. In Vértices de observação - Mudanças: Psicoterapia e Estudos Psicossociais, 5,11-31. São Paulo: UMESP (Universidade Metodista de São Paulo).

Crouch, E. C., Bloch, S. \& Wanlass, J. (1994). Therapeutic factors: interpersonal and intrapersonal mechanisms. In A. Fuhriman. \& G.M. Burlingame (1994): Handbook of group psychotherapy - an empirical and clinical synthesis (pp269-315). New York: John Wiley.

Dies, R. R. (1992). Models of group psychotherapy: sifting through confusion. International Journal of Group Psychotherapy, 42, 1-17.

Engel, J. V. (1983). Características especiais de um grupo de psicoterapia breve e de baixa renda. Jornal Brasileiro de Psiquiatria, 32, 139-146.

Flanagan, J. C. (1954).The critical Incident technique. Psychological Bulletin, 51: 327-358.

Fuhriman, A., Burlingame, G. (1994). Group Psychotherapy Research and Practice. In A. Fuhriman, \& G.M. Burlingame (1994). Handbook of group psychotherapy - an empirical and clinical synthesis. New York: John Wiley. 
Giovanella, L., \& Amarante, P. (1994). O enfoque estratégico do Planejamento em Saúde Mental. In P. Amarante (org). Psiquiatria Social e Reforma Psiquiátrica (pp.113-147). Rio de Janeiro: Editora Fiocruz.

Ishara, S. (1996). Psicoterapia de Grupo em Hospital Dia: Proposição de uma Metodologia de Estudo. Dissertação de Mestrado não publicada, Faculdade de Medicina de Ribeirão Preto, USP, Ribeirão Preto-SP.

Kaplan, H. I., Sadock, B. J., Grebb, J. A. (1997a). Transtornos de Humor. In H.I. Kaplan, B. J. Sadock, J. A. Grebb (1997). Compêndio de Psiquiatria - Ciências do Comportamento e Psiquiatria Clínica ( $7^{\mathrm{a}}$ ed., pp:493-544), Porto Alegre: Artes Médicas.

(1997b). Transtornos de Ansiedade. In Compêndio de Psiquiatria - Ciências do Comportamento e Psiquiatria Clínica $\left(7^{\mathrm{a}}\right.$ ed., pp: 545-583), Porto Alegre: Artes Médicas.

(1997c). Psicoterapias. In H.I.

Kaplan, B. J. Sadock, J. A. Grebb (1997). Compêndio de Psiquiatria - Ciências do Comportamento e Psiquiatria Clínica ( $7^{\mathrm{a}}$ ed., pp:771808), Porto Alegre: Artes Médicas.

Kivlighan, D. M. Jr., \& Goldfine, D.C. (1991). Endorsement of therapeutic factors as a function of stage of group development and interpersonal atitudes. Journal of Counseling Psychology, 38: 150-158.

Kinoshita, R.T. (1987). Uma experiência pioneira: a reforma psiquiátrica italiana. In: Saúde Mental e Cidadania ( $2^{\mathrm{a}}$ ed., p.0828). São Paulo: Edições Mandacaru - Plenário dos Trabalhadores em Saúde Mental.

Klein, R. K. (1996). Psicoterapia de grupo a curto prazo. In Kaplan, H.I., \& Sadock, B.J. Compêndio de Psicoterapia de Grupo ( $3^{\mathrm{a}}$ ed., pp. 215225). Porto Alegre: Artes Médicas.

Kude, V. M. M. (1997). Como se faz um Projeto de Pesquisa Qualitativa em Psicologia. Psico, 28, 9-34. 
Lancetti, A. (1993). Clínica grupal com psicóticos - a grupalidade que os especialistas não entendem. In A. Lancetti (org). Saúde e Loucura - grupos e coletivos, (nº 4, pp.155-171). São Paulo: Hucitec.

Lima, M. G., Pondé, M. P., Azevedo, R. C. S., Carvalho, T. F. R., \& Guimarães, L. (1993). Avaliação dos níveis de ansiedade através da Escala de Hamilton em pacientes submetidos à psicoterapia breve grupal dinâmica. Jornal Brasileiro de Psiquiatria, $42: 381-386$.

Luz, M. T. (1994). História de uma marginalização: a política oficial de saúde mental - ontem, hoje, alternativas e possibilidades.In P. Amarante (org). Psiquiatria

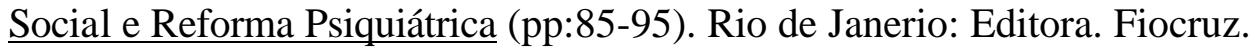

Mackenzie, K. R. (1996). Time Limited Group Psychotherapy. International Journal of Group Psychotherapy, 46, 41-60.

(1999a).The psychotherapies today: an overiew. In Anais do VII Ciclo em Saúde Mental, pp.16-27.

(1999b).Interpersonal Patterns as an Integrative Language for the Psychotherapies: An Aproach for the new mellenium. In Anais do VII Ciclo em Saúde Mental, pp.28-39.

(1999c). Psychotherapy Group and Group Program Evaluation. In Anais do VII Ciclo em Saúde Mental, pp.40-52. (1999d). The future of the psychotherapies. In Anais do VII Ciclo em Saúde Mental, p.53-57.

Marsiglia, R. G. (1987). Os cidadãos loucos no Brasil. A cidadania como processo. In: Saúde Mental e Cidadania ( $2^{\mathrm{a}}$ ed., p.0828). São Paulo: Edições Mandacaru - Plenário dos Trabalhadores em Saúde Mental.

Maton, B. I. (1993). Moving beyond the individual level of analysis in mutual help group research: an ecological paradigm. Journal of Applied Behavioral Science, 29, 272-286.

Minayo, M. C. S. (1996). O desafio do conhecimento: pesquisa qualitativa em saúde (4 ${ }^{\mathrm{a}}$ ed.). São Paulo: Hucitec / Abrasco. 
Mishna, F. (1996). In their own words: therapeutic factors for adolescents who have learning desabilities. International Journal of Group Psychotherapy, 46, 265-273.

Moura Neto, F. D. M. (1987). Bases para uma reforma psiquiátrica. In $\underline{\text { Saúde }}$ Mental e Cidadania ( $2^{\mathrm{a}}$ ed., p.5765). São Paulo: Edições Mandacaru - Plenário dos Trabalhadores em Saúde Mental.

O'Brien, P. J. (1994). The uses of an observation team with a parent support group. International Journal of Group Psychotherapy, 44, 233-238.

Organização Panamericana de Saúde (1990). Reestruturação da Assistência Psiquiátrica: Bases Conceituais e Caminhos para sua Implementação. Editores: Uscátegui, R. G \& Levan, I., Instituto Mário Magri, Milão - Itália, p.07-63.

Osório, L. C. (1997). Processos obstrutivos nos sistemas sociais nos grupos e nas instituições. In: D.E. Zimermam. \& L.C.Osório et al.(1997). Como Trabalhamos com Grupos, (cap.6, pp.69-74). Porto Alegre: Artes Médicas.

Padrão, M. L. (s/d). O Estatuto do Doente Mental. Mimeografado.

Patton. M. Q. (1983). Qualitative Evaluation Model. London: Sage Publications.

(1990). Qualitative Evaluation and research methods. London: Sage Publications.

Piper, W. E. (1996). Psicoterapia de grupo e pesquisa. In Kaplan, H.I., \& Sadock, B.J. Compêndio de Psicoterapia de Grupo ( $3^{\mathrm{a}}$ ed., p.559565). Porto Alegre: Artes Médicas.

Resende, H. (1992). Política de saúde mental no Brasil: uma visão histórica. In: S. A. Tunis \& N. R. Costa (org). Cidadania e Loucura - Políticas de Saúde Mental no Brasil ( $3^{\mathrm{a}}$ ed., pp.1573). Petrópolis: Vozes.

Rosemberg, S. A, \& Zimet, C. N. (1995). Brief group treatment and maneged mentall health care. International Journal of Group Psychotherapy; 45, 367-379. 
Sadock, B. J; Kaplan, H. I. (1996). Diagnóstico Clínico na Psicoterapia de Grupo. In H. I. Kaplan, \& B. J. Sadock. Compêndio de Psicoterapia de Grupo (3 ${ }^{a}$ ed., pp. 50-63). Porto Alegre: Artes Médicas.

Salvendy, J. T. (1996). Seleção, Preparação dos Pacientes e Organização do grupo. In H. I. Kaplan \& B. J. Sadock. Compêndio de Psicoterapia de Grupo (3 ${ }^{\mathrm{a}}$ ed., pp. 63-72). Porto Alegre: Artes Médicas.

Scheidlinger, S. (1994). An overview of nine decades of group psychotherapy. Hospital and Community Psychiatry; 45, 217-225.

(1996). História da psicoterapia de grupo. In H.I. Kaplan \& B. J. Sadock. Compêndio de Psicoterapia de Grupo ( $3^{\mathrm{a}}$ ed., pp. 0613). Porto Alegre: Artes Médicas.

Schaughnessy, P., \& Kivlighan Jr., D. M. (1995). Using group participants'perceptions of therapeutic factors to form client typologies. Small Group Research, 26, 250-268.

Scherer, E. A. (1999). Estudos de Reuniões de Equipe Geral em um HospitalDia Psiquiátrico. Dissertação de Mestrado não publicada, Faculdade de Medicina de Ribeirão Preto, USP, Ribeirão Preto-SP.

Schichtman, A., Alves, D. S. N., Silva, R. C. (1996). Políticas de saúde mental no Brasil. Jornal Brasileiro de Psiquiatria, 45, 127-128.

Schopler, J. H., \& Galinsk, M. J. (1993). Support groups as opens systems: a model for practice and research. Health \& Social Work, 18, 195-207.

Selltiz, C., Wrighstsman, L. S., Cook, S.W. (1987). Métodos de Pesquisa nas Relações Sociais ( $2^{\text {a }}$ ed.).L. H. Kidder (org). São Paulo: EPU.

Silva Filho, J. F.(1992). A medicina, a psiquiatria e a doença mental. In S.A. Tunis \& N.R. Costa (org). Cidadania e Loucura - Políticas de Saúde Mental no Brasil ( $3^{\mathrm{a}}$ ed., pp.75102). Petrópolis: Vozes.

Simon, R. (1989). Psicologia Clínica Preventiva - Novos Fundamentos (2 6 ed.). São Paulo: EPU. 
(1995). Escala de Diagnóstico da Adaptação Operacionalizada -

EDAO. Revista Mudança, 3-4, 13-23.

(s/d). Escala do diagnóstico da adaptação operacionalizado (EDAO). In Escala do diagnóstico da Adaptação Operacionalizado - Mudanças: Psicoterapia e Estudos Psicossociais, 3, 9-23. São Paulo: Editora IMS (Edims).

Soldz, S; Budman, S., Davis, M., \& Demby, A. (1993). Beyond the interpersonal circumplex in group psychotherapy: the structure and relationship to outcome of the individual group member interpersonal process scale. Journal of Clinical Psychology; 49, 551-563.

Stone, M. H; Lewis, C. M; Beck, A. P. (1994). The structure of Yalom's Curative Factors Scale. International Journal of Group Psychoterapy; 44, 239-245.

Vasconcelos, E. M. (1990). Avaliação dos avanços recentes em legislação psiquiátrica no plano internacional - uma contribuição ao debate sobre a reforma da lei psiquiátrica no Brasil. Jornal Brasileiro de Psiquiatria; 39 , 288-235.

(1995). Avaliação de serviços no contexto da desinstitucionalização psiquiátrica: revisão de metodologias e estratégias de pesquisa. Jornal Brasileiro de Psiquiatria, 44, 189-197.

Vilela, J. A. A., Pantalião, E. A., Del-Bem, C. M., \& Zuardi, A. W. (1999). Estudo descritivo de um serviço ambulatorial vinculado a um serviço de emergência psiquiátrica. Jornal Brasileiro de Psiquiatria, 48, 245-252.

Vinogradov, S; \& Yalom, I. D. (1992). Manual de Psicoterapia de Grupo. Porto Alegre: Artes Médicas. (trad. Dayse Batista).

Wheelan, S. A., Hochberger, J. M. (1996). Validation studies of the group development questionaire. Small Group Research, 27, 143-170.

World Health Organization (1993) Classificação dos Transtornos Mentais e de comportamento da CID-10. Porto Alegre: Artes Médicas.

Yalom, I. (1970). The theory and practice of group psychotherapy. New York: Basic Books. 
Yasui, S. (1989). Caps: aprendendo a perguntar. In A. Lancetti. (org). Saúde e Loucura - grupos e coletivos ( $2^{\mathrm{a}}$ ed., $\mathrm{n}^{\circ}$ 1, p.4759). São Paulo: Hucitec.

Zimermam, D. E \& Osório, L. C. et al..(1997). Como Trabalhamos com Grupos. Porto Alegre: Artes Médicas.

Zimermam, D. E. (1997a). Fundamentos teóricos. In D.E. Zimermam \& L.C.Osório et al. (1997). Como Trabalhamos com Grupos (cap.1, pp. 23-31). Porto Alegre: Artes Médicas.

(1997b). Classificação geral dos grupos. In D.E.

Zimermam; L.C.Osório (1997). Como Trabalhamos com Grupos (cap.7, pp. 75-81). Porto Alegre: Artes Médicas. (1997c). Como agem os grupos terapêuticos. In D.E. Zimermam \& L.C.Osório et al. (1997). Como Trabalhamos com Grupos (cap.12, pp. 119-125). Porto Alegre: Artes Médicas.

Referências Bibliográficas normatizadas de acordo com "Publication Manual of Americam Psychological Asssociation, $4^{a}$ ed. Sashington: APA, 1994”. 


\section{SUMMARY}

\section{INVESTIGATING POSSIBILITIES AND LIMITS IN A SUPPORT GROUP WITH PSYCHIATRIC OUTPATIENTS}

The use of group psychotherapy in mental health attendance, specially in institutional contexts, it has been expanding in a accelerated rhythm in our reality, with no correlate expansion of researches in this area, according to the specialized literature. This study aims to contribute with the knowledge about this practice, by studying in natural conditions, a support group with psychiatric outpatients (16 sessions) in a mental health center of Ribeirão Preto. It was objectified to understand the limits and the possibilites of this type of treatment, by describing group's development through the cordinator's handling and investigating the therapeutic factors existing on this group according to the participants'perspective. The group was composed by ten patients of both sexes, aging 29 to 65 years old, mainly married and having not complete junior hight school. With several psychiatric diagnoses, they pointed out the principal use of anxiolytics and antidepressant medication. Observation and audio-recorded tapes of the group, and the Critical Incident Questionaire (CIQ) constituted the main sources of data. Consultations to the patients' files and field notes were also accomplished during the period of data collection. The data were analyzed by qualitative and quantitative procedures. Based on sessions' transcription it was made the thematic and dynamic description of all the group'meetings. The analysis of the group's handling was accomplished by procedures of categorial content analysis of the coordinator's interventions $(\mathrm{N}=1904)$. The analysis of the patients'answers to the CIQ $(\mathrm{N}=112)$ was also accomplished by procedures of categorial content analysis, based on a descriptive system of the therapeutic factors proposed in the literature. The data origineted from the files and the fields notes were used on the comprehension of the data derived from the analysis of the other sources. The analysis of the cordinator's handling of the group resulted in eight categories of intervention: reiteration (48\%); investigation (16\%); elucidation (13\%); confrontation (11\%); setting rules (7\%); evaluation (2\%); guideness (1\%) and interrupted speach $(2 \%)$. The descriptive system of the therapeutic factores used on the initial analysis of QIC was not sufficient for classification all the answers, driving us to new categories. Our results point for the presence of ten categories derived from the patients' perception of the group: universality (23\%); vicarious learning (22\%); distant (13\%); hopeless (9\%); instilation of hope $(7 \%)$; altruism $(6 \%)$; acceptance (5\%); self disclosure (4\%); guideness (4\%) and catharsis (3\%). Just $5 \%$ of CIQ 's answers were not classify. These results show us the presence of therapeutic and non therapeutic factors in the group, according to the patients'perspective. Thus, this study contribute to an understanding about the way patients lived the process of this group - according to the meanings produced by them after the group'sessions - and, in conjunction with their clinical condition and with the understanding of the group development through the description of the cordinator'handling, it shows some possibilities and some limits of this type of treatment, considering the context where it happens and the patients that usually compose those types of groups. (FAPESP)

Key words: support groups; psychiatric outpatient. 


\section{ERRATA}

À página 36, houve um erro em relação ao autor responsável pela enunciação referida no texto:

"Em relação à definição de fator terapêutico apresentada por BLOCH et al. (1979), a partir da sua revisão sobre a classificação dos fatores terapêuticos..."

Substituir BLOCH et al. (1979) por CROUCH, BLOCH \& WANLASS (1994)

A mesma substituição deve ser efetuada àpagina 40:

“Concordamos com BLOCH et al. (1979) que definem fator terapêutico como um elemento da terapia que contribui para a melhora de uma condição do paciente e pode ser decorrente das ações do terapeuta do grupo, dos outros membros do grupo e do próprio paciente"” (p.271).

Substituir BLOCH et al. (1979) por CROUCH et al. (1994)

E também àpagina 85:

“... Se considerarmos, segundo referido por BLOCH et al (1979) fator terapêutico como "um elemento da terapia..."

Substituir BLOCH et al. (1979) por CROUCH et al. (1994). 